Pontifícia Universidade C $_{\text {atóllca }}$

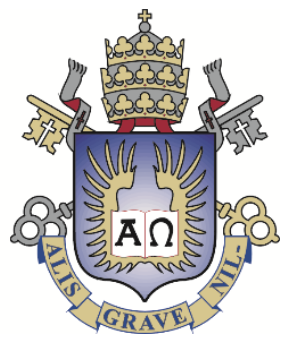

Bruno Pinheiro Pires

Estudo Experimental da Tenacidade de Rochas Gnáissicas para Diferentes Graus de Alteração.

Dissertação de Mestrado

Dissertação apresentada ao Programa de Pós-graduação em Engenharia Civil da PUC-Rio como requisito parcial para obtenção do grau de Mestre em Engenharia Civil.

Orientadora: Profa. Raquel Quadros Velloso Coorientador: Prof. Rubem Porto Junior 


\section{Estudo Experimental da Tenacidade de Rochas Gnáissicas para Diferentes Graus de Alteração.}

Dissertação apresentada como requisito parcial para obtenção do grau de Mestre pelo Programa de Pósgraduação em Engenharia Civil da PUC-Rio. Aprovada pela Comissão Examinadora abaixo assinada.

Prof ${ }^{a}$. Raquel Quadros Velloso

Orientadora

Departamento de Engenharia Civil e Ambiental - PUC-Rio

Prof. Rubem Porto Junior Coorientador

Departamento de Petrologia e Geotectônica - UFRRJ

Prof. Eurípedes do Amaral Vargas Junior Departamento de Engenharia Civil e Ambiental - PUC-Rio

Prof. Emilio Velloso Barroso Departamento de Geologia - UFRJ

Prof. Marcio da Silveira Carvalho Coordenador Setorial do Centro Técnico Científico - PUC-Rio 
Todos os direitos reservados. É proibida a reprodução total ou parcial do trabalho sem autorização do autor, da orientadora e da universidade.

Bruno Pinheiro Pires

Graduou-se em Geologia pela Universidade Federal Rural do Rio de Janeiro, em Seropédica, Rio de Janeiro, em julho de 2013. Durante a graduação atuou na área de Geologia de Engenharia. Ingressou no Mestrado na Pontifícia Universidade Católica do Rio de Janeiro, em março de 2016, desenvolvendo dissertação na linha de pesquisa de Mecânica das Rochas.

Ficha Catalográfica

Pires, Bruno Pinheiro

Estudo Experimental da Tenacidade de Rochas Gnáissicas para Diferentes Graus de Alteração / Bruno Pinheiro Pires; orientadora: Raquel Quadros Velloso; coorientador: Rubem Porto Junior. - Rio de Janeiro: PUC, Departamento de Engenharia Civil e Ambiental, 2018.

$$
\text { v., } 113 \text { f.: il. ; } 29,7 \mathrm{~cm}
$$

Dissertação (Mestrado) - Pontifícia Universidade Católica do Rio de Janeiro, Departamento de Engenharia Civil e Ambiental, 2018.

Inclui referências bibliográficas.

1. Engenharia Civil - Teses. 2. Tenacidade à fratura. 3. Grau de alteração. 4. Gnaisse. I Velloso, Raquel Quadros. II Porto Jr., Rubem. III Pontifícia Universidade Católica do Rio de Janeiro. Departamento de Engenharia Civil e Ambiental. IV Título. 
À minha mãe Ivana, ao meu pai Orlando e ao meu irmão Caio. 


\section{Agradecimentos}

Gostaria de agradecer primeiramente a Deus, por me guiar, dar forças e me fazer aprender que tudo acontece no seu devido tempo.

À minha mãe Ivana e ao meu pai Orlando, pela educação e princípios que me deram. Sempre preocupados com a minha educação, prepararam-me para o mundo, a encarar os problemas de frente, a viver com a cabeça erguida e com dignidade. Ao meu irmão Caio, mesmo mais novo, sempre me ensinando algo diferente.

Às minhas avós Norma e Isis (in memoriam), aos meus avôs (in memoriam), às minhas tias Fátima, Marilene e Marisa, ao meu tio Gilmar e a toda a minha família que tanto me apoia e me ajuda. Vocês são minha base.

À minha namorada e melhor amiga, Shayanne Soeiro, por me aturar, me aconselhar e me apoiar por tantos anos.

À minha orientadora Raquel Velloso, por todos os ensinamentos, estímulos, paciência durante todo o trabalho, pela confiança depositada em mim e pelo suporte financeiro que viabilizou esta pesquisa.

Ao meu orientador e amigo Rubem Porto Jr., grande Rubão, ensinando-me um pouco de Geologia desde os tempos da Rural.

Ao professor Vargas, pela honra de poder desfrutar dos seus conhecimentos e pelas contribuições neste trabalho.

À "equipe" de mecânicas de rochas que formamos e que foi fundamental na realização deste trabalho: Bruno Viana, Rafaella Villela e Darío Prada.

Aos técnicos do Laboratório de Estruturas da PUC-Rio, em especial Euclides e Rogério.

Aos técnicos Márcio e Alexandre, do Laboratório de Mecânica da PUC-Rio.

À pedreira Bangu por fornecer as rochas e a todos os seus funcionários por estarem sempre à disposição para nos ajudar a retirar os blocos.

Ao meu grande amigo, que está sempre na caminhada comigo desde os tempos da graduação, Jean Santarelli.

Aos amigos geólogos e mestrandos da PUC que me ajudaram neste trabalho, Mauro Junior e Luiz Felipe.

Ao CETEM e ao meu amigo Schwenck pela realização dos ensaios de DRX. 
A todos os amigos que fiz na PUC-Rio e principalmente à minha turma maravilhosa: Jainor, Alan, Andrea, Luana, Larissa, Carol, Raquel, Ana Luiza, Mariana, Fernanda, Erica, Alice, Franco, Arthur, Paul, Raul e todos os outros.

Aos meus amigos de fora da PUC que acompanharam toda a luta e sempre torceram por mim: Stella, Bruna, Lívia, Raquel, Leonardo, Roberto, Bruno, Thiago, Paulo, Priscila, Carol e Daniela.

Aos professores e funcionários do departamento de Engenharia Civil e Ambiental da PUC-Rio, em especial à professora Michéle Casagrande por todos os conselhos no início do mestrado.

À PUC-Rio pela bolsa de isenção concedida na primeira metade do curso e pela oportunidade de cursar o Mestrado nesta instituição que tanto admiro.

À CAPES pelo apoio financeiro, fundamental, durante a segunda metade do curso.

A todas as outras pessoas que participaram direta e indiretamente da minha caminhada nesta fase. 


\section{Resumo}

Pires, Bruno Pinheiro; Velloso, Raquel Quadros (Orientadora); Porto Jr., Rubem (Coorientador). Estudo Experimental da Tenacidade de Rochas Gnáissicas para Diferentes Graus de Alteração. Rio de Janeiro, 2018. 113 p. Dissertação de Mestrado. Departamento de Engenharia Civil e Ambiental, Pontifícia Universidade Católica do Rio de Janeiro.

O estudo da mecânica da fratura aplicada às rochas vem se desenvolvendo desde os anos 60. Seu principal parâmetro, a tenacidade à fratura, quantifica a capacidade que a rocha possui para absorver energia até atingir a ruptura. Seu conhecimento é muito importante em diversas áreas da engenharia de rochas, como análise de estabilidade de taludes rochosos, processos de desmonte de rochas, escavações na mineração, fraturamento hidráulico, mecânica de terremotos, dentre outros. O presente estudo apresenta e analisa a influência do grau de alteração na tenacidade à fratura, no modo I de propagação, através de ensaio CCNDB (corpo de prova em forma de disco brasileiro com entalhe em "chevron"), de rochas gnáissicas da cidade do Rio de Janeiro. Amostras de diferentes graus de alteração foram caracterizadas quanto às suas propriedades mineralógicas, físicas (porosidade e peso específico) e mecânicas (resistência à compressão puntiforme, resistência à compressão uniaxial e resistência à tração). Nos resultados obtidos, são discutidas e realizadas correlações da tenacidade com as propriedades analisadas. Foi possível verificar que o grau de alteração é diretamente proporcional à porosidade e inversamente proporcional às resistências (compressão uniaxial e tração). Sendo assim, a rocha alterada apresenta maior porosidade e menor resistência, quando comparada com rochas menos alteradas (sãs e medianamente alteradas). A tenacidade à fratura para rochas medianamente alteradas é 45,9\% menor do que para rochas sãs, e 86,7\% menor para rochas alteradas. Assim sendo, o grau de alteração das rochas influencia, de maneira significativa, todas as propriedades analisadas.

\section{Palavras-chave}

Tenacidade à fratura; grau de alteração; gnaisse. 


\section{Abstract}

Pires, Bruno Pinheiro; Velloso, Raquel Quadros (Advisor); Porto Jr., Rubem (Co-advisor). Experimental Study of Fracture Toughness of Gneiss Rocks in Different Weathering Classes. Rio de Janeiro, 2018. 113 p. Dissertação de Mestrado. Departamento de Engenharia Civil e Ambiental, Pontifícia Universidade Católica do Rio de Janeiro.

The study of fracture mechanics applied to rocks has been developed since 1960. The main parameter, fracture toughness, quantifies the rock ability to absorb energy until it ruptures. This knowledge is very important in several areas of rock engineering, such as stability analysis of rocky slopes, rock clearing processes, mining excavations, hydraulic fracturing, earthquake mechanic, among others. The study presents and analyzes the influence of the weathering class in the mode I fracture toughness of gneiss rocks in the city of Rio de Janeiro, using Cracked Chevron Noched Brazilian Disc (CCNDB). Samples of different classes were characterized for their mineralogical, physical (porosity and dry specific weight) and mechanical properties (point load strength, uniaxial compressive strength and tensile strength). The obtained results allowed correlations to be made between toughness and the other analyzed properties. By doing this, it was possible to verify that the weathering class of a rock is directly proportional to the porosity and inversely proportional to the strengths (uniaxial compressive and tensile). Thus, the highly weathered rock presents higher porosity and lower strength when compared to less weathered rocks (sound and moderated). The fracture toughness for moderately weathered rocks is $45,9 \%$ lower than sound rocks, and $86,7 \%$ smaller for highly weathered rocks. Therefore, the class of weathering rocks influences all the analyzed properties in a significant way.

\section{Keywords}

Fracture toughness; weathering class; gneiss. 


\section{Sumário}

1 Introdução 20

$\begin{array}{lll}1.1 & \text { Objetivos } & 21\end{array}$

$\begin{array}{lll}1.2 & \text { Justificativa } & 21\end{array}$

$\begin{array}{lll}1.3 & \text { Área do estudo } & 21\end{array}$

1.4 Estrutura da dissertação 22

2 Revisão bibliográfica 23

2.1 Contexto histórico da Mecânica da Fratura 23

2.2 Mecânica da Fratura aplicada às rochas 25

2.2.1 Modos de carregamento e deslocamento 25

2.2.2 Critério de energia 28

2.2.3 Fator de intensidade das tensões 30

2.3 Tenacidade 33

2.3.1 Dimensões do entalhe e geometria do corpo de prova 34

2.3.2 Anisotropia do material 35

2.3.3 Efeito do tamanho dos grãos 36

$\begin{array}{lll}\text { 2.3.4 Efeito do teor de umidade } & 37\end{array}$

2.4 Método cracked chevron notched brazilian disc (CCNDB) 37

3 Materiais e métodos 42

3.1 Materiais 42

3.1.1 Contexto geológico da área 46

3.1.2 Descrição macroscópica das rochas 47

3.1.3 Preparação dos corpos de prova 49

3.2 Metodologia 52

3.2.1 Análise petrográfica 53

3.2.2 Análise de difração de raio $X$

3.2.3 Caracterização de índices físicos 55 
3.2.4 Ensaio esclerométrico (martelo de Schmidt) 58

3.2.5 Ensaio de resistência à compressão puntiforme 60

3.2.6 Ensaio de resistência à compressão uniaxial 62

3.2.7 Ensaio indireto de resistência à tração (ens. Brasileiro) 64

3.2.8 Ensaio de tenacidade à fratura CCNDB 66

4 Apresentação e discussão dos resultados 71

$\begin{array}{lll}4.1 & \text { Análise petrográfica } & 71\end{array}$

4.2 Análise de difração de raio $X \quad 75$

4.3 Caracterização de índices físicos 77

4.4 Ensaio esclerométrico (martelo de Schmidt) 82

4.5 Ensaio de resistência à compressão puntiforme 84

4.6 Ensaio de resistência à compressão uniaxial 86

4.7 Ensaio indireto de resistência à tração (ens. Brasileiro) 90

4.8 Ensaio de tenacidade à fratura CCNDB 93

5 Conclusões e sugestões para futuros trabalhos 104

5.1 Conclusões 104

5.2 Sugestões para futuros trabalhos 107

6 Referências bibliográficas 108 


\section{Lista de Figuras}

Figura 1.1 - Imagem aérea da Pedreira Bangu. 22

Figura 2.1 - Estado de tensão em coordenadas polares e cartesianas. 26

Figura 2.2 - Modos fundamentais de propagação da fissura. 26

Figura 2.3 - Combinação dos modos fundamentais de propagação da fissura.

Figura 2.4 - Placa infinita com furo elíptico submetida a tensões uniformes de tração.

Figura 2.5 - Placa infinita com abertura central sob carregamento biaxial.

Figura 2.6 - Detalhe das tensões aplicadas próximas à extremidade da fissura em um material elástico.

Figura 2.7 - Geometria do corpo de prova para o método CCNDB (forma de disco brasileiro com entalhe em "chevron").

Figura 3.1 - Frente de produção da Pedreira Bangu, local de coleta dos blocos de rocha sã.

Figura 3.2 - Retroescavadeira com concha auxiliando na retirada dos blocos.

Figura 3.3 - Retroescavadeira com rompedor hidráulico auxiliando na retirada de blocos.

Figura 3.4 - Litotipos estudados (I. rocha sã, III. rocha medianamente alterada, IV. rocha alterada).

Figura 3.5 - Extração de testemunhos utilizando a perfuratriz da marca Hilti, modelo DD 200.

Figura 3.6 - Caixa de consolidação para extração de corpos de prova de rocha alterada.

Figura 3.7 - Cortadora metalográfica, utilizada para cortar corpos de prova com $54 \mathrm{~mm}$ de diâmetro.

Figura 3.8 - Serra de bancada e suporte bipartido para testemunhos com $75 \mathrm{~mm}$ de diâmetro.

Figura 3.9 - Retífica automática de corpos de prova utilizada para facear topo e base de todos os corpos de prova. 
Figura 3.10 - Suporte bipartido confeccionado para auxiliar o faceamento dos corpos de prova CCNDB. 52

Figura 3.11 - Microscópio óptico utilizado nas análises microscópicas. 54

Figura 3.12 - Microscópio óptico utilizado para geração de mosaico de imagens da lâmina.

Figura 3.13a - Preparação das amostras / Figura 3.13b Difratômetro utilizado.

Figura 3.14a - Dessecador e bomba de vácuo utilizado / Figura 3.14b - Sistema montado para medir massa submersa e massa saturada.

Figura 3.15 - Martelo de Schmidt utilizado, tipo $L$ da marca Proceq. $\quad 59$

Figura 3.16 - Princípio de funcionamento do esclerômetro. $\quad 59$

Figura 3.17 - Equipamento utilizado para o Point Load Test. 60

Figura 3.18 - Configuração da geometria requerida para o Teste Diametral (a) e Teste Axial (b).

Figura 3.19 - Direções corretas e incorretas da aplicação da carga para obtenção de valores máximos e mínimos de Is.

Figura 3.20 - Variação do Is em função do ângulo $\beta$, entre o eixo do corpo de prova e a foliação da rocha, para forças aplicadas paralelamente ao plano de foliação.

Figura 3.21 - Ensaio de resistência à compressão uniaxial realizado na máquina de ensaios universais da marca MTS, modelo 810.

Figura 3.22 - Resistência à compressão de rochas anisotrópicas.

Figura 3.23 - Ensaio para determinação da resistência à tração indireto (Ensaio Brasileiro).

Figura 3.24 - Procedimento realizado para a confecção do entalhe chevron, para ensaios CCNDB.

Figura 3.25 - Ensaio para determinação da tenacidade à fratura do tipo CCNDB.

Figura 4.1 - Mosaico da lâmina petrográfica da rocha sã (luz transmitida polarizada).

Figura 4.2 - Mosaico da lâmina petrográfica da rocha sã (luz transmitida polarizada com nicóis cruzados). 72

Figura 4.3 - Mosaico da lâmina petrográfica da rocha medianamente alterada (luz transmitida polarizada).

Figura 4.4 - Mosaico da lâmina petrográfica da rocha medianamente alterada (luz transmitida polarizada com nicóis cruzados). 
Figura 4.5 - Mosaico da lâmina petrográfica da rocha alterada (luz transmitida polarizada).

Figura 4.6 - Mosaico da lâmina petrográfica da rocha alterada (luz transmitida polarizada com nicóis cruzados).

Figura 4.7 - Difratograma da amostra de rocha sã.

Figura 4.8 - Difratograma da amostra de rocha medianamente alterada.

Figura 4.9 - Difratograma da amostra de rocha alterada.

Figura 4.10 - Variação da porosidade em função do grau de alteração das rochas.

Figura 4.11 - Variação do peso específico seco em função do grau de alteração das rochas.

Figura 4.12 - Variação do peso específico seco em função da porosidade.

Figura 4.13 - Variação do índice Q do Martelo de Schmidt em função do grau de alteração das rochas.

Figura 4.14 - Variação dos índices de resistências puntiformes (axial e diametral) em função do grau de alteração das rochas.

Figura 4.15 - Variação dos índices de resistências puntiformes em função da porosidade.

Figura 4.16 - Resultado do ensaio de compressão uniaxial em função do grau de alteração das rochas.

Figura 4.17 - Curvas tensão-deformação típicas dos litotipos estudados.

Figura 4.18 - Corpos de prova rompidos após o ensaio de compressão uniaxial.

Figura 4.19 - Variação da resistência à compressão uniaxial em função da porosidade.

Figura 4.20 - Variação da relação módulo elasticidade/resistência à compressão uniaxial em função da porosidade.

Figura 4.21 - Resultados do ensaio Brasileiro em função do grau de alteração das rochas.

Figura 4.22 - Variação da resistência à tração obtida no ensaio Brasileiro em função da direção da foliação.

Figura 4.23 - Variação da resistência à tração obtida no ensaio Brasileiro em função da porosidade. 
Figura 4.24 - Corpos de prova utilizados no ensaio CCNDB nos seus respectivos graus de alteração e direção do entalhe.

Figura 4.25 - Escopo da geometria válida para corpos de prova CCNDB.

Figura 4.26 - Resultado do ensaio CCNDB em função do grau de alteração.

Figura 4.27 - Variação da tenacidade à fratura obtida no ensaio CCNDB em função da direção do entalhe com a foliação.

Figura 4.28 - Variação da tenacidade à fratura obtida no ensaio CCNDB em função da porosidade.

Figura 4.29 - Variação dos resultados médios da tenacidade à fratura (CCNDB) em função dos resultados médios de resistência à compressão uniaxial.

Figura 4.30 - Variação dos resultados médios da tenacidade à fratura (CCNDB) em função dos resultados médios de resistência à tração (ensaio Brasileiro).

Figura 4.31- Variação dos resultados médios da tenacidade à fratura (CCNDB) e dos resultados médios de resistência à tração (ensaio Brasileiro) em função das respectivas porosidades.

Figura 4.32 - Curvas força-deslocamento típicas dos litotipos estudados.

Figura 4.33 - Curvas força-deslocamento dos corpos com clip gauge. 103 


\section{Lista de Tabelas}

Tabela 2.1 - Dimensões geométricas padrão para corpos de prova CCNDB sugeridas pela ISRM.

Tabela 3.1 - Sugestão da ISRM (2007 apud Marques, 2010) para classificação e descrição de maciços rochosos (traduzido).

Tabela 4.1 - Resumo da caracterização dos índices físicos.

Tabela 4.2 - Resultados médios das porosidades encotradas no presente trabalho, em Santos (2004) e Menezes filho (1993).

Tabela 4.3 - Resultados médios dos pesos específicos secos encontrados no presente trabalho, em Santos (2004) e Menezes filho (1993).

Tabela 4.4 - Resumo dos resultados do ensaio esclerométrico. 83

Tabela 4.5 - Resumo dos resultados do ensaio de Point Load. 85

Tabela 4.6 - Resumo dos resultados do ensaio de compressão uniaxial.

Tabela 4.7 - Comparação dos resultados de compressão uniaxial obtidos.

Tabela 4.8 - Resumo dos resultados obtidos no ensaio Brasileiro. $\quad 91$

Tabela 4.9 - Ensaios CCNDB realizados. 94

Tabela 4.10 - Resumo dos resultados obtidos no ensaio CCNDB. 96

Tabela 4.11 - Média dos resultados obtidos no ensaio CCNDB. 97

Tabela 4.12 - Resultados médios dos ensaios CCNDB obtidos no presente trabalho e em Santos (2004). 102

Tabela 5.1- Valores médios dos ensaios realizados. 106 


\section{Lista de Símbolos e Abreviações}

\begin{tabular}{|c|c|}
\hline ISRM & International Society of Rock Mechanics \\
\hline CCNDB & Cracked Chevron Notched Brazilian Disc \\
\hline $\mathrm{CB}$ & Chevron Bend \\
\hline SR & Short Rod \\
\hline $\mathrm{DRX}$ & Difração de Raio X \\
\hline$\sigma$ & Tensão normal \\
\hline$\tau_{\mathrm{i}}$ & Tensão cisalhante no plano \\
\hline$\tau_{0}$ & Tensão cisalhante fora do plano \\
\hline $\mathrm{K}_{\mathrm{IC}}$ & Tenacidade à fratura no modo I de carregamento \\
\hline $\mathrm{K}_{\mathrm{IIC}}$ & Tenacidade à fratura no modo II de carregamento \\
\hline $\mathrm{K}_{\text {IIIIC }}$ & Tenacidade à fratura no modo III de carregamento \\
\hline$E$ & Energia total \\
\hline$\pi$ & Energia potencial fornecida pela energia de \\
\hline & deformação interna (fruto da ação de forças externas) \\
\hline$W s$ & Trabalho necessário para criar nova superfície \\
\hline$\pi_{0}$ & Energia potencial de uma placa intacta \\
\hline B & Espessura \\
\hline$\gamma_{s}$ & Energia de superfície do material \\
\hline$G$ & Taxa de alívio de energia \\
\hline $\mathrm{G}_{\mathrm{c}}$ & $\begin{array}{l}\text { Taxa crítica de alívio de energia de deformação } \\
\text { geradora de fissura }\end{array}$ \\
\hline $\mathrm{K}_{\mathrm{c}}$ & Fator de intensidade de tensões \\
\hline $\mathrm{E}$ & Módulo de elasticidade \\
\hline$v$ & Coeficiente de Poisson \\
\hline$G_{I C}$ & $\begin{array}{l}\text { Valor crítico de alívio de energia de deformação para } \\
\text { o modo I de carregamento }\end{array}$ \\
\hline$P_{\max }$ & Força máxima aplicada \\
\hline $\mathrm{D}$ & Diâmetro do corpo de prova \\
\hline
\end{tabular}




\begin{tabular}{|c|c|}
\hline$Y_{\min }^{*}$ & $\begin{array}{l}\text { Valor crítico (mínimo) do fator de intensidade de } \\
\text { tensão adimensional para o corpo de prova }\end{array}$ \\
\hline$a_{0}$ & Comprimento inicial do entalhe em "chevron" \\
\hline$a_{1}$ & Comprimento final do entalhe em "chevron" \\
\hline$\alpha_{0}$ & Dimensão geométrica do corpo de prova \\
\hline$\alpha_{1}$ & Dimensão geométrica do corpo de prova \\
\hline$\alpha_{B}$ & Dimensão geométrica do corpo de prova \\
\hline$u$ & $\begin{array}{l}\text { Constante determinada em função de } \alpha_{0} \text { e } \alpha_{B} \\
\text { tabelada na sugestão da ISRM (1995) }\end{array}$ \\
\hline$v$ & $\begin{array}{l}\text { Constante determinada em função de } \alpha_{0} \text { e } \alpha_{B} \\
\text { tabelada na sugestão da ISRM (1995) }\end{array}$ \\
\hline $\mathrm{D}_{\mathrm{s}}$ & Diâmetro da serra \\
\hline$h_{c}$ & Profundidade do corte \\
\hline$M_{w}$ & Massa de vazios \\
\hline$M_{\text {sat }}$ & Massa saturada \\
\hline$M_{s}$ & Massa dos constituintes sólidos \\
\hline$V$ & Volume total \\
\hline$V_{v}$ & Volume de vazios \\
\hline$V_{w}$ & Volume de vazios saturados \\
\hline$\rho_{w}$ & Massa específica da água \\
\hline$V_{s}$ & Volume dos constituintes sólidos \\
\hline$n$ & Porosidade \\
\hline$e$ & Índice de vazios \\
\hline$\rho_{d}$ & Massa específica seca \\
\hline$\gamma_{d}$ & Peso específico seco \\
\hline$g$ & Aceleração da gravidade \\
\hline$\rho_{\text {sat }}$ & Massa específica saturada \\
\hline$\gamma_{\text {sat }}$ & Peso específico saturado \\
\hline$\rho_{s}$ & Massa específica dos constituintes sólidos \\
\hline$\gamma_{s}$ & Peso específico dos constituintes sólidos \\
\hline UCS & Resistência à compressão uniaxial \\
\hline$Q$ & Valor de rebote do martelo de Schmidt \\
\hline$I_{\mathrm{s}}$ & Índice de resistência puntiforme \\
\hline
\end{tabular}




$\begin{array}{ll}\mathrm{P} & \text { Carga ou força aplicada na ruptura } \\ \mathrm{D}_{\mathrm{e}} & \text { Diâmetro equivalente do corpo de prova } \\ \sigma_{\mathrm{c}} & \text { Resistência à compressão uniaxial } \\ A_{0} & \text { Área inicial da seção transversal do corpo de prova } \\ \sigma_{t} & \text { Resistência à tração } \\ t & \text { Espessura do corpo de prova } \\ C V & \text { Coeficiente de variação }\end{array}$


"Quanto mais aumenta nosso conhecimento, mais evidente fica nossa ignorância",

(Jhon F. Kennedy) 


\section{1 \\ Introdução}

A mecânica da fratura é a ciência que estuda o comportamento e os processos mecânicos envolvidos na propagação de fissura, trinca ou fenda; sendo, portanto, essencial em muitas áreas da engenharia de rochas, como: estabilidade de taludes rochosos, escavações na mineração, processos de fragmentação de rochas (desmonte, por exemplo), estabilidade de poços de petróleo, fraturamento hidráulico, mecânica de terremotos, entre outros.

O principal parâmetro da mecânica da fratura é a tenacidade à fratura. É considerada uma propriedade intrínseca importante do material e definida como a capacidade que o material possui em absorver a energia até a ruptura. Ela indica a magnitude da resistência à fratura para resistir a propagação da fissura.

A propagação da fissura na maioria dos materiais frágeis ocorre preferencialmente no modo I. Mesmo em situações onde o modo II é favorecido, o modo I parece assumir o controle do crescimento da mesma (Backers, 2001). Por esta razão, aliado ao fato de o modo I ser analisado e produzido, experimentalmente, de maneira mais fácil que os demais modos, ele concentra grande maioria dos estudos desenvolvidos na mecânica de fraturas.

A partir dos anos 80, aumentaram-se consideravelmente as pesquisas relacionadas à mecânica da fratura de materiais frágeis, como rochas, concretos, cerâmicas, compósitos e alguns polímeros. Muitos esforços foram dedicados a desenvolver metodologias experimentais, com o objetivo de medir os parâmetros relacionados, e o refinamento de modelos analíticos e numéricos para análise do comportamento dos materiais.

Existem diversas metodologias para determinar a tenacidade à fratura de rochas. A International Society of Rock Mechanics (ISRM) sugere três ensaios: Chevron Bend (CB), Short Rod (SR) e Cracked Chevron Notched Brazilian Disc (CCNBD). As duas primeiras foram sugeridas em 1988 (ISRM, 1988); e a terceira, em 1995 (ISRM, 1995). 
Na presente pesquisa, optou-se por se realizar o ensaio CCNDB, por ser este o mais específico dentre os sugeridos pela ISRM para determinação do modo I de propagação de fissuras, diferente dos outros ensaios que realizam uma abordagem mais simples.

\section{1}

\section{Objetivos}

O presente trabalho tem como objetivo principal analisar e comparar a influência do grau de alteração na tenacidade à fratura. $\mathrm{O}$ estudo visa a entender melhor as relações da tenacidade com propriedades físicas e mecânicas da rocha.

As propriedades físicas e mecânicas relacionadas neste trabalho foram porosidade, peso específico, resistência à compressão puntiforme, resistência à compressão uniaxial e resistência à tração.

Para avaliar os graus de alteração foram confeccionadas lâminas petrográficas e foram realizadas análises mineralógicas de difração de raio $\mathrm{X}$ (DRX).

\section{2}

\section{Justificativa}

O clima na cidade do Rio de Janeiro propicia a ação de mecanismos modificadores das propriedades físicas e químicas dos minerais e rochas. Como mencionado anteriormente, a compreensão dos mecanismos de fratura motivou o desenvolvimento do presente trabalho. Tal compreensão é muito importante em projetos de engenharia que envolvem rochas, principalmente para estudos de instabilidade de taludes rochosos, como as quedas de blocos de rochas encontradas nas encostas cariocas, conforme relatado por Vargas et al. (2012).

\section{3 Área do estudo}

O material analisado no presente trabalho foi retirado da Pedreira Bangu, situada no bairro de Bangu, no município do Rio de Janeiro, RJ (figura 1.1). Essa pedreira está instalada na base do Morro do Sandá, pequena elevação de 86 metros de altura localizada na vertente norte do Maciço da Pedra Branca. 
A pedreira tem como principal matéria-prima a brita. $\mathrm{Na}$ época em que foram coletadas as amostras, tinha um volume diário em torno de 100 a 120 caminhões comercializados por dia.

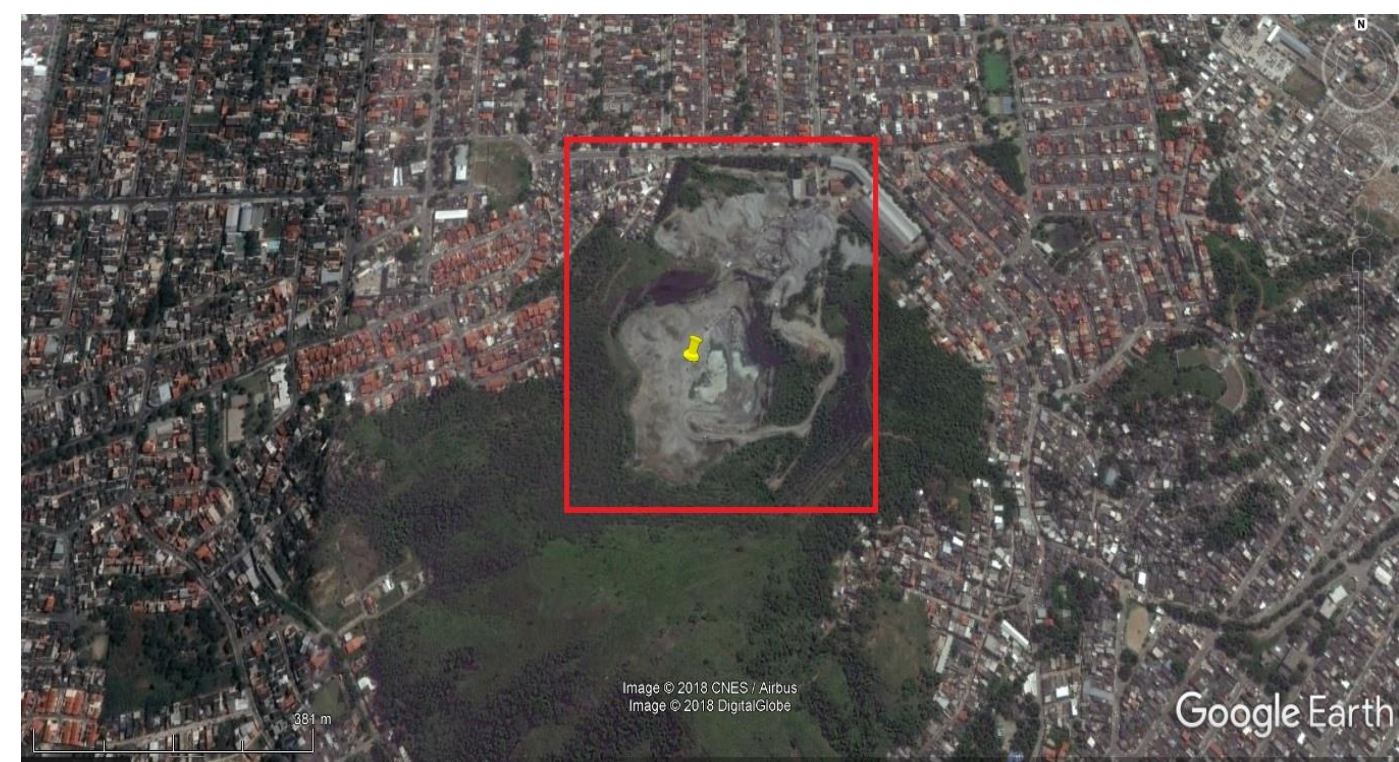

Figura 1.1 - Imagem aérea da Pedreira Bangu. O marcador ao centro do polígono mostra a atual cava da pedreira (fonte: Google Earth, JAN/2018).

\section{4}

\section{Estrutura da dissertação}

Este trabalho foi organizado em seis capítulos, sendo esta parte introdutória constituída da justificativa do estudo e da definição dos objetivos gerais e específicos.

No Capítulo 2, é apresentada uma revisão bibliográfica dividida de acordo com os temas estudados. São eles: mecânica de fraturas, mecânica de fraturas aplicada às rochas, tenacidade e método Cracked Chevron Notched Brazilian Disc (CCNDB).

O Capítulo 3 descreve detalhadamente os materiais e as metodologias utilizadas no programa experimental. São apresentados os equipamentos, setups e normas seguidas para a realização dos ensaios.

O Capítulo 4 consiste na apresentação, na análise e na discussão dos resultados obtidos nos ensaios realizados.

No Capítulo 5 são apresentadas as conclusões adquiridas durante a realização deste trabalho. Contém também sugestões para trabalhos futuros. 


\section{2 Revisão bibliográfica}

Neste capítulo será abordada a revisão bibliográfica, separada nos seguintes assuntos: contexto histórico da mecânica da fratura, mecânica da fratura aplicada a rochas, tenacidade e método Cracked Chevron Notched Brazilian Disc.

\section{1 Contexto histórico da Mecânica da Fratura}

A Mecânica da Fratura tem sua importância para o homem desde a Préhistória, na chamada Idade da Pedra Lascada, Paleolítico, quando ele aprendeu a fabricar facas, lanças, machados, pontas de flechas entre outras ferramentas ou objetos de pedra. Com o tempo, esses materiais foram aprimorados, e houve o surgimento das atividades mineradoras para que o homem pudesse obter blocos de rochas e metais.

$\mathrm{Na}$ Idade Antiga, egípcios e gregos também dominavam a técnica de entalhar e/ou trincar pedras para a confecção de monumentos antigos. Com o Renascimento, no final da Idade Média e durante a Idade Moderna, quando houve uma grande explosão científica e cultural, ocorreu a utilização de mármores na construção das Igrejas, como colunas ou placas no piso, e na intensa produção de esculturas em rochas, de autoria de grandes artistas da época.

Naquela época, as pessoas já começavam a se preocupar com as fraturas. Galileu Galilei foi uma das primeiras pessoas a investigar a influência do tamanho das trincas nas estruturas para entender por que os corpos quebravam.

Em 1678, a lei da elasticidade dos materiais foi apresentada por Robert Hooke. Em 1773, Charles Augustin de Coulomb, através de ensaios compressivos em rochas, introduziu o critério de Coulomb. Thomas Young, em 1808, e Simeon Deniz Poisson, em 1829, apresentaram, respectivamente, os conceitos de Módulo de Elasticidade e Coeficiente de Poisson. No século XIX, quase cem anos depois, Otto Mohr desenvolveu o critério de Mohr-Coulomb, uma forma generalizada da teoria de Coulomb, usado até os dias de hoje. 
Em 1921, durante a Primeira Guerra Mundial, o engenheiro aeronáutico Alan Arnold Griffith, visando a explicar o mecanismo de falha dos materiais frágeis, desenvolveu a Mecânica da Fratura. Utilizando amostras de vidro, introduziu uma falha artificial nos corpos de prova e chegou à conclusão de que a teoria da elasticidade se aplicava a corpos fissurados.

Com base na análise de tensão apresentado por Charles Inglis em 1913, Griffith estabeleceu uma relação entre a tensão de fratura e o tamanho da trinca, conhecida como Balanço Energético de Griffith. Ele mostrou que a resistência à tração dos materiais frágeis, encontrada em laboratório, era menor que os valores calculados teoricamente e que os materiais apresentavam microfissuras, que eram concentradores de tensões. Nas rochas, esses concentradores de tensões se dão em forma de vazios ou contato entre os grãos minerais.

A concentração de tensões nas extremidades das microfissuras internas do material causa a propagação das trincas. Também pode aumentar a tensão local até um valor maior que o necessário para o rompimento das ligações atômicas. A propagação das fissuras pode não ocorrer se a energia fornecida não for suficiente para vencer a extensão dela, resultante da resistência coesiva molecular.

Portanto, a ruptura de um corpo sólido rígido com comportamento frágil abrange dois fatores: tensão, que necessita ser, localmente, maior que a coesão molecular; e energia, cujo processo deve ser energicamente possível.

Westergaard (1939) resolveu o problema de determinação de tensões e deformações em corpos fissurados através de um método analítico. A trinca passa a ter uma configuração reta e plana e não mais elíptica, como proposto por Inglis. Esta nova configuração é a mais próxima da realidade (Ingraffea, 1977 apud Marchiori, 1997).

A partir de 1948, George Irwin, através de uma série de trabalhos publicados, desenvolveu o conceito de alívio de energia, reportando-se à Teoria de Griffith (Pehovaz-Alvarez, 2004). Ele propôs uma modificação na abordagem do assunto. Ao invés de analisar a energia específica de superfície, averiguou a "velocidade" com que a energia de deformação é transformada em energia de superfície em função do comprimento da trinca, ou seja, a variação da liberação da energia de deformação durante o fraturamento (Bortolucci, 1993). Utilizando o princípio de Westergaard, Irwing demonstrou que as tensões e os deslocamentos próximos à extremidade de uma trinca poderiam ser representados por uma 
simples constante correlacionável com a taxa de liberação de energia, conhecida como fator de intensidade de tensões.

Posteriormente, houve muitos estudos derivados dos clássicos trabalhos de Griffith e Irwin, mas apenas na década de 60 começaram a surgir estudos de mecânica da fratura em rochas.

\section{2 \\ Mecânica da Fratura aplicada às rochas}

Como mencionado no item anterior, a mecânica da fratura nas rochas começou a se desenvolver a partir dos anos 60. Com base nos estudos existentes, foi possível concluir que a Mecânica da Fratura elástica linear em materiais resistentes com ruptura frágil, caso das rochas, produzia bons resultados. Isso significa que os materiais se comportam elasticamente no início da ruptura.

Seu principal objetivo é estabelecer as condições para uma fissura de determinada dimensão ter início e se propagar sob um determinado carregamento. Consequentemente, determinar o fator de segurança para ruptura por fraturamento da estrutura analisada (Anderson, 1995).

Atkinson (1987) aponta, como principais fatores que consolidam a base da mecânica da fratura de rochas, modos de carregamento e deslocamento nas extremidades da fissura, critério de energia, análise da intensidade de tensões, estado de tensões nas extremidades das fissuras, fraturamento estático e dinâmico, avaliação e análise dos parâmetros mecânicos envolvidos.

\subsubsection{Modos de carregamento e deslocamento}

Em função das tensões aplicadas e da existência de diferentes configurações do carregamento nas extremidades das fissuras, são produzidos diferentes modos de deslocamento na ponta da trinca. Em geral, a extremidade da fissura está sujeita a 3 (três) variedades de tensões: tensão normal $(\sigma)$, tensão cisalhante no plano $\left(\tau_{\mathrm{i}}\right)$ e tensão cisalhante fora do plano $\left(\tau_{0}\right)$ (figura 2.1 ). 


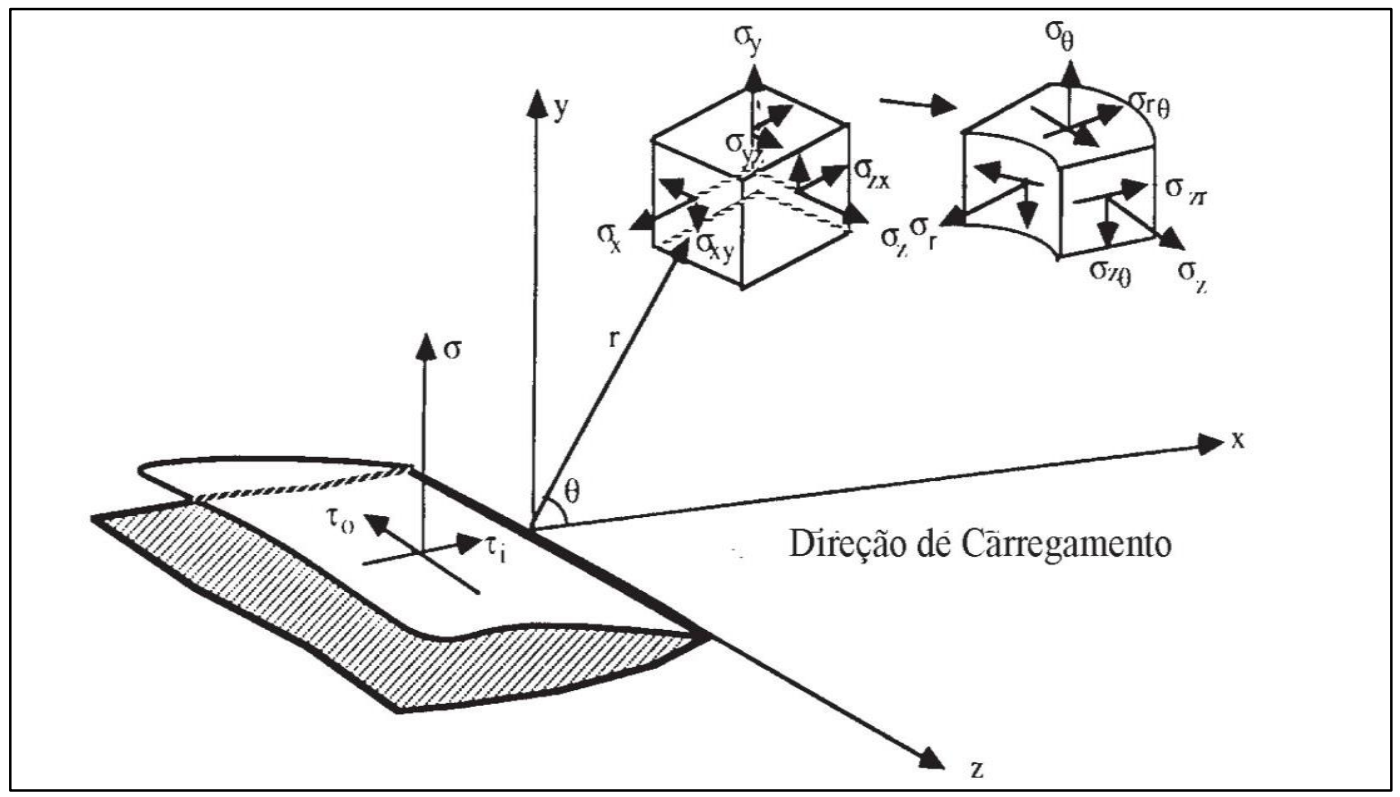

Figura 2.1 - Estado de tensão em coordenadas polares e cartesianas (Whittaker et al., 1992).

Em função dos estados de tensões há 3 (três) modos básicos de propagação das fissuras (figura 2.2):

Modo I - É o modo de abertura da trinca devido à tensão normal, onde as superfícies da fissura se separam com o deslocamento perpendicular em relação ao plano da fissura;

Modo II - É o modo deslizante devido ao cisalhamento no plano, onde as superfícies da fissura se movem uma sobre a outra em sentindo perpendicular à frente da fissura. $\mathrm{O}$ deslocamento se dá paralelamente a este plano e perpendicularmente à frente da fissura.

Modo III - Também é um modo deslizante devido a cisalhamento, porém as superfícies da fissura deslizam uma sobre a outra em sentido paralelo à frente da fissura, fora do plano de cisalhamento.

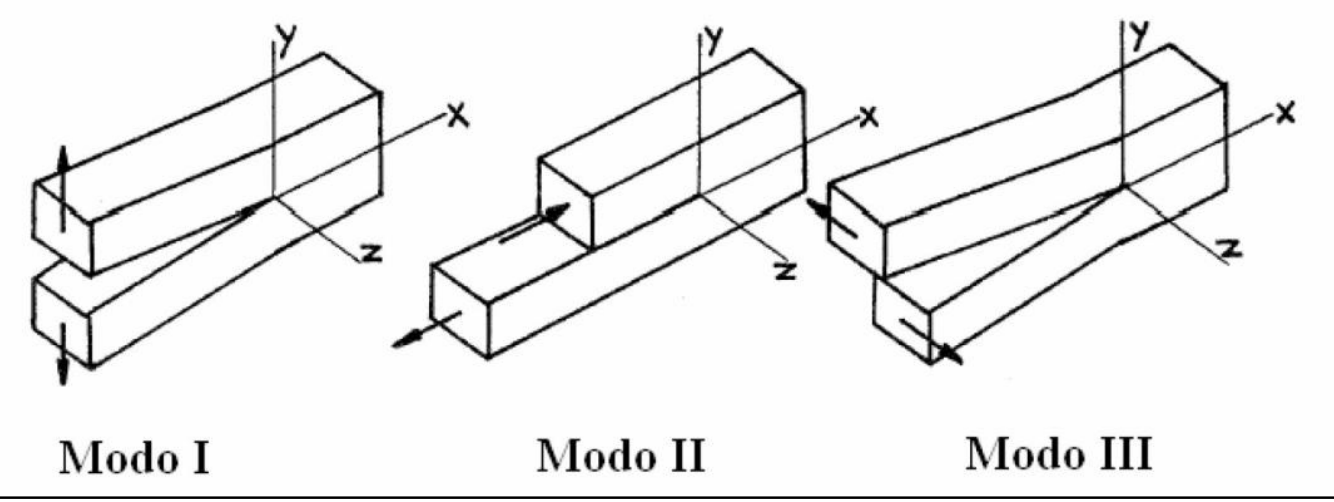

Figura 2.2 - Modos fundamentais de propagação da fissura (Tada et al., 2000 apud Donovan, 2003). 
A determinação da tenacidade à fratura dos materiais é feita para um determinado modo de propagação. Desta maneira, os ensaios são configurados de modo que proporcione apenas um tipo de tensão. Por exemplo, somente a tração, desta maneira será obtida a tenacidade da fratura relativa ao modo I, representada por $\mathrm{K}_{\mathrm{IC}}$. Analogamente existem as tenacidades $\mathrm{K}_{\mathrm{IIC}}$ e $\mathrm{K}_{\mathrm{IIIC}}$.

Entre os três tipos, o modo I é o mais encontrado nas aplicações de engenharia. É também o modo mais fácil de ser analisado e de se produzir experimentalmente. Em razão disso, absorve a grande parte dos estudos desenvolvidos na mecânica de fraturas.

Podem ocorrer também combinações dos três modos básicos. São os chamados carregamentos do tipo misto, onde pode haver superposições dos modos (figura 2.3). Essas combinações são suficientes para descrever os casos tridimensionais mais gerais de tensões e de campo de deformações locais na ponta da fissura (Hudson \& Harrison, 1997 apud Backers, 2001).

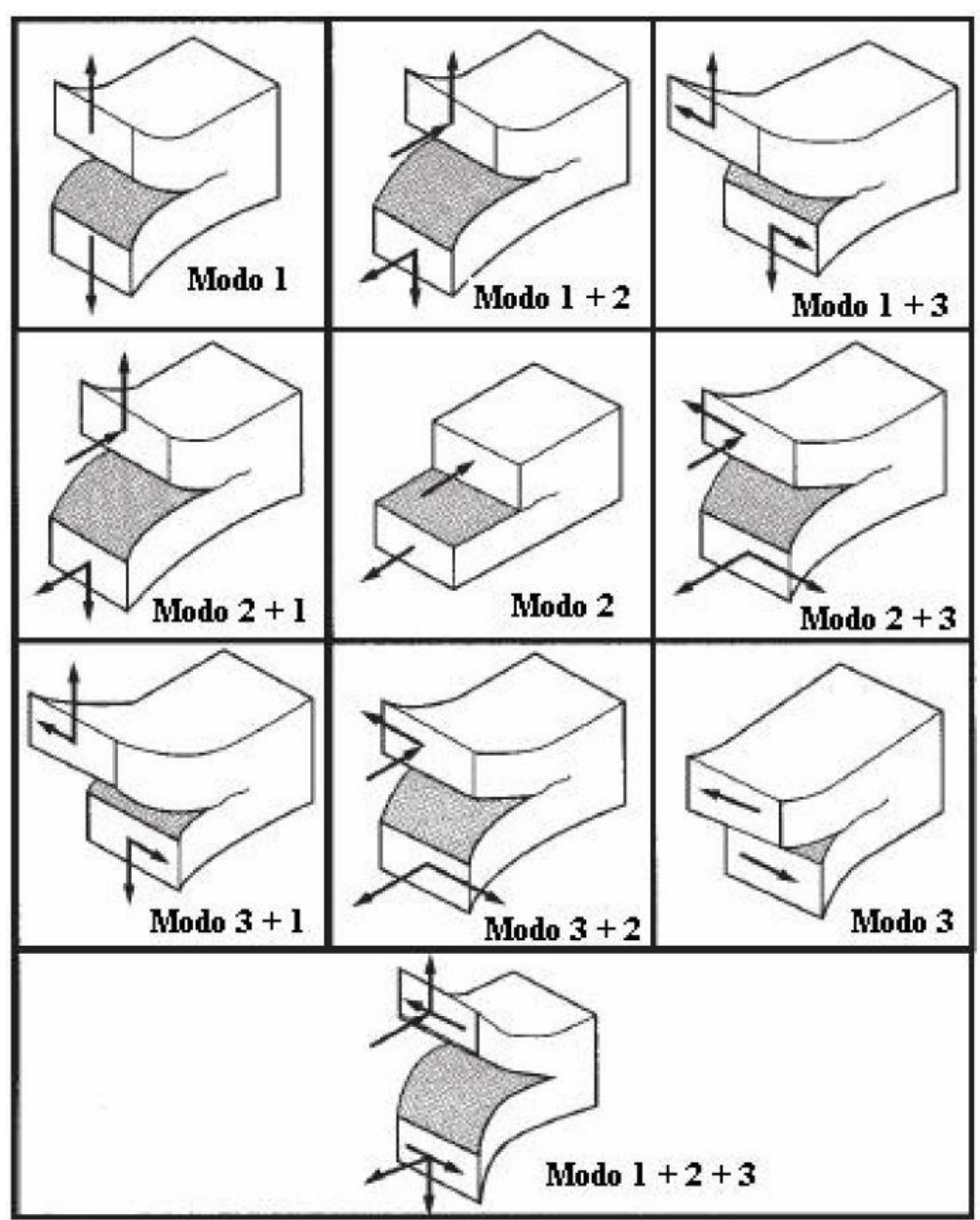

Figura 2.3 - Combinação dos modos fundamentais de propagação da fissura (Hudson \& Harrison, 1997 apud Backers, 2001). 


\subsubsection{Critério de energia}

Uma das alternativas para se abordar a análise de fissuras é o critério de energia. Tem como justificativa que uma fratura só ocorre quando a energia disponível para o crescimento de uma fissura é suficientemente grande de modo que supere a resistência do material (Anderson, 1995). Essa resistência está associada com a energia da superfície ou com o tipo de dissipação de energia associado à propagação da fissura.

A partir do conceito de balanço energético de Griffith, ponto inicial no desenvolvimento da mecânica da fratura, junto com os conceitos da primeira lei da termodinâmica, determina que um sistema inicialmente em desequilíbrio passa a um estado de equilíbrio e necessariamente a energia do sistema diminui. Griffith, baseado nos estudos de Inglis, aplicou este conceito à formação de fissuras. A figura 2.4 mostra uma fratura elíptica em uma placa tracionada uniformemente. Para haver aumento da fissura é necessário que esteja disponível uma energia potencial suficiente na placa de modo que supere a energia de superfície do material.

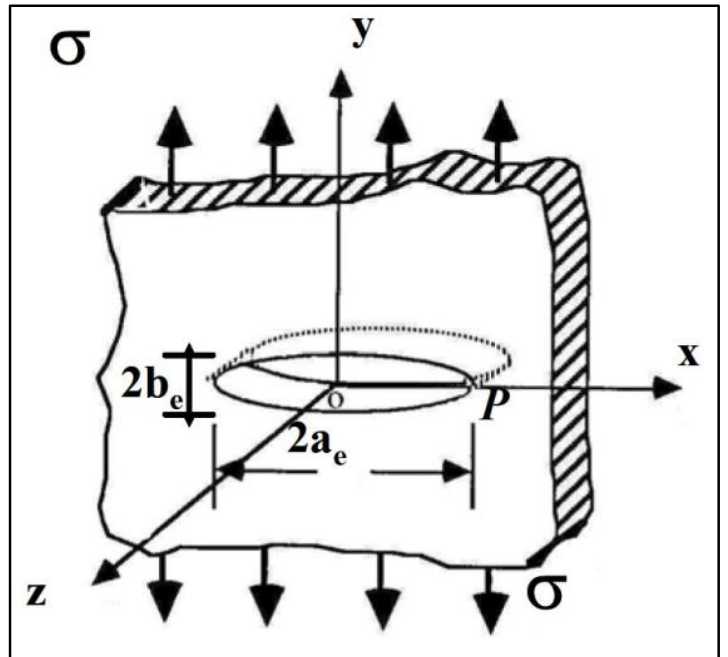

Figura 2.4 - Placa infinita com furo elíptico submetida a tensões uniformes de tração (Whittaker $e t$ al., 1992).

Sob condições de equilíbrio, o incremento na área da fissura, dA.

$$
\frac{d E}{d A}=\left(\frac{d \pi}{d A}\right)+\left(\frac{d W_{S}}{d A}\right)=0
$$


Onde:

$E$ - energia total;

$\pi$ - energia potencial fornecida pela energia de deformação interna (fruto da ação de forças externas);

$W s$ - trabalho necessário para criar nova superfície.

Para a placa fissurada da figura 2.4, Grifitth demonstrou a seguinte expressão:

$$
\pi=\pi_{0}-\left(\pi \sigma^{2} \frac{B}{E}\right)
$$

\section{Onde:}

$\pi_{0}$ - energia potencial de uma placa intacta;

B - espessura da placa.

Como a formação da fissura requer a criação de duas novas superfícies, temos $W_{S}$ :

$$
W_{S}=4 a B \gamma_{s}
$$

Onde:

$\gamma_{s}$ - energia de superfície do material.

Temos:

$-\left(\frac{d \pi}{d A}\right)=\left(\pi \sigma^{2} \frac{a}{E}\right)$

$\frac{d W_{S}}{d A}=2 \gamma_{S}$

Resolvendo as equações 2.4 e 2.5 temos:

$$
\sigma_{f}=\left(\frac{2 E \gamma_{s}}{\pi a}\right)^{1 / 2}
$$

A taxa de variação na energia potencial, $\pi$, com a área da fissura, ou taxa de alívio de energia, G, é:

$$
G=\pi \sigma^{2} \frac{a}{E}
$$




\subsubsection{Fator de intensidade das tensões}

Outra alternativa para abordar a análise de fissuras é a utilização do fator de intensidade das tensões. Tensões e deslocamentos em materiais cujo comportamento é elástico linear podem ser caracterizados por um único parâmetro, fator de concentração de tensões ou SIF-K (stress intensity factor). A tenacidade à fratura representa a medida da concentração crítica de tensões na extremidade de uma fissura requerida para ser iniciada e/ou ser propagada. Pode ser também o campo de tensões elásticas na extremidade da fissura.

A taxa crítica de alívio de energia de deformação geradora de fissura é representada por $G_{c}$ e pode ser expressa pela seguinte expressão:

$$
G_{C}=\frac{K_{c}^{2}\left(1-v^{2}\right)}{E}
$$

\section{Onde:}

$\mathrm{K}_{\mathrm{c}}-$ fator de intensidade de tensões;

E - módulo de elasticidade;

$v$ - coeficiente de Poisson.

A taxa representa a energia necessária para criar uma nova área de superfície. Griffith estabeleceu valores para que, quando a taxa de alívio de energia de tensão atingir um determinado valor crítico, ocorra a iniciação das fissuras. Para o modo I de carregamento, temos:

$$
G_{I}=G_{I C}
$$

Onde:

$G_{I C}$ - valor crítico de alívio de energia de deformação para o modo I de carregamento.

O $G_{I C}$ é um parâmetro constante para um determinado material, estabelecendo sua capacidade de resistência à extensão das fraturas ou fissuras. Em termos de intensidade de tensões, temos:

$$
K_{I}=K_{I C}
$$


Onde:

$K_{I C}$ - tenacidade à fratura no modo I de carregamento.

A condição representada pela equação 2.10 controla a dimensão da fratura, que continuará a se propagar enquanto essa condição for satisfeita, portanto, enquanto a força incidente $K_{I}$ para a fratura for maior ou igual à resistência do material $\left(K_{I C}\right)$, ela irá se propagar e, somente quando for menor, cessará.

Segundo Whittaker et al. (1992), a tenacidade à fratura no modo I (KIC $)$ é uma constante que não deve variar com fatores como: dimensões do corpo, geometria da fissura, taxa de carregamento, condições do ambiente, entre outros; sendo, portanto, uma propriedade intrínseca do material.

Como mencionado anteriormente, Westergaard (1939) publicou método analítico para determinar tensões e deformações em corpos fissurados. Com base nesse método, podem ser obtidos, através de uma função que satisfaz as condições de equilíbrio, de compatibilidade e de contorno do problema. As figuras 2.5 e 2.6 mostram as componentes de tensões aplicadas à extremidade de uma fratura em um meio linear elástico e homogêneo.

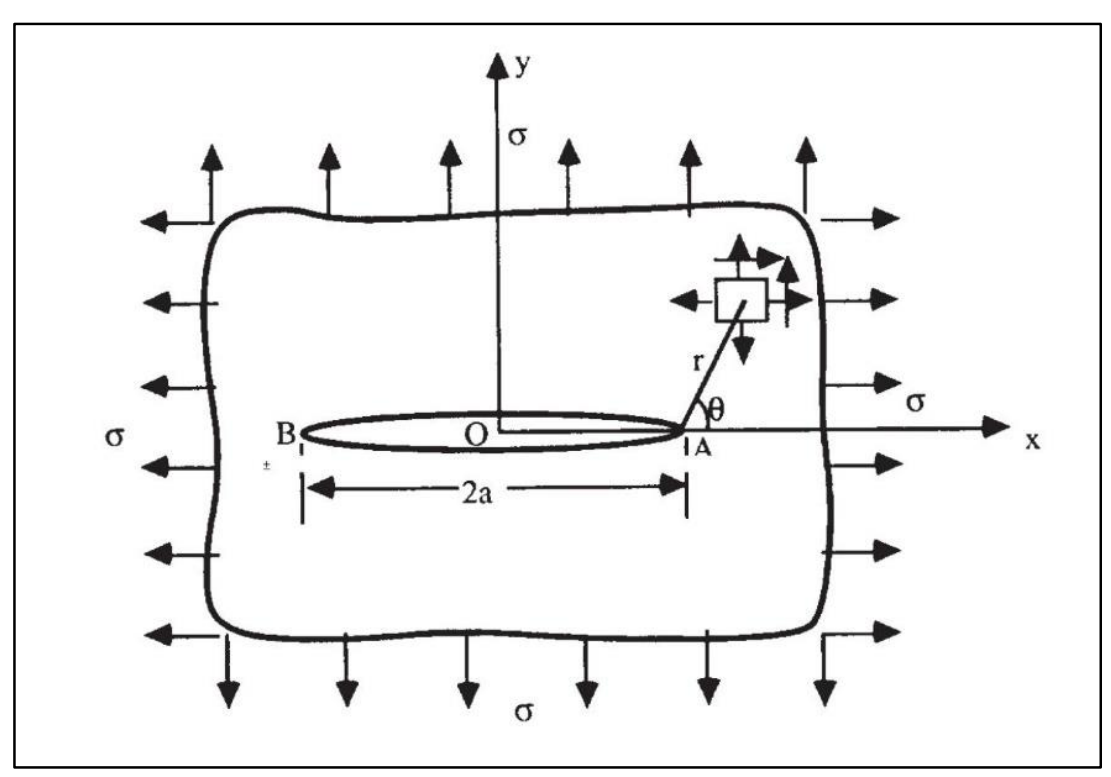

Figura 2.5 - Placa infinita com abertura central sob carregamento biaxial (Almeida, 1999). 


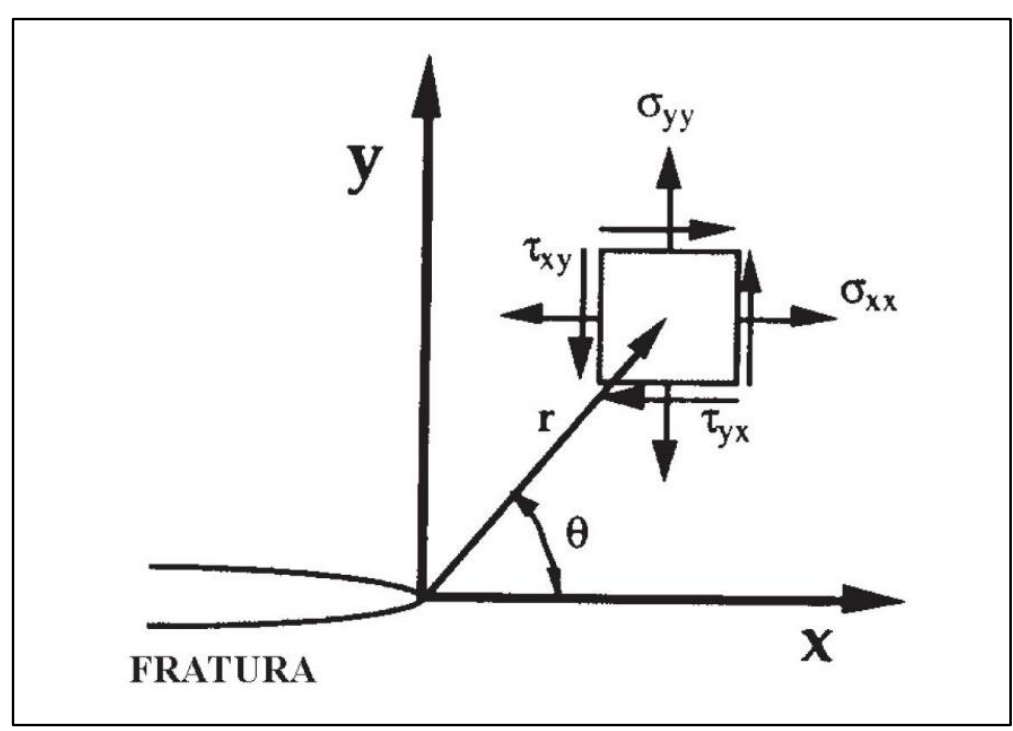

Figura 2.6 - Detalhe das tensões aplicadas próximas à extremidade da fissura em um material elástico (Almeida, 1999).

A placa infinita, carregada biaxialmente, representada pelas duas figuras anteriores, com abertura central de comprimento $2 \mathrm{a}$, tem como condições de contorno:
a. $\sigma_{y}=0$ para $-a<x<a$ e $y=0$;
b. $\sigma_{y}=\sigma$ para $x= \pm \infty$;
c. $\sigma_{y}=\infty$ para $x= \pm a$

(eq. 2.11)

As condições de contorno acima são válidas desde que a concentração de tensões seja infinita na extremidade da abertura. As equações 2.14, 2.15 e 2.16 definem o estado de tensões na extremidade da abertura:

$$
\begin{aligned}
\sigma_{x} & =\sigma \sqrt{a} / 2 r \cos \frac{\theta}{2}\left(1-\sin \frac{\theta}{2} \sin \frac{3 \theta}{2}\right) \\
\sigma_{y} & =\sigma \sqrt{a} / 2 r \cos \frac{\theta}{2}\left(1+\sin \frac{\theta}{2} \sin \frac{3 \theta}{2}\right) \\
\sigma_{x y} & \left.=\sigma \sqrt{a} / 2 r \sin \frac{\theta}{2} \cos \frac{\theta}{2} \cos \frac{3 \theta}{2}\right)
\end{aligned}
$$

Assumindo $\theta=0$, temos:

$$
\sigma_{y}=\sigma \sqrt{a} / 2 r
$$

Substituindo, temos:

$$
\sigma_{y} \sqrt{2 \pi r}=\sigma \sqrt{a} / 2 r \sqrt{2 \pi r}=\sigma \sqrt{\pi a}
$$


$\mathrm{O}$ valor de $\sigma \sqrt{\pi a}$ é constante ao longo do eixo x. Trata-se do fator de intensidade de tensões no modo $\mathrm{I}\left(\mathrm{K}_{\mathrm{I}}\right)$. Assim $\mathrm{K}_{\mathrm{I}}=\sigma \sqrt{\pi a}$, portanto $\mathrm{K}_{\mathrm{I}}$ é um produto da tensão pela raiz quadrada da abertura da fissura e de $\pi$, $\log$ o a unidade que mede a tenacidade à fratura é dada por $\mathrm{F} / \mathrm{L}^{2} \mathrm{~L}^{0.5}$.

\section{3}

\section{Tenacidade}

A tenacidade à fratura é o principal parâmetro na mecânica da fratura. É a propriedade mecânica que o material apresenta para absorver e dissipar energia durante o processo de fraturamento. A resistência indicada por ela é apresentada em termos de intensificação de tensões ao avanço da fratura (Ferreira, 2002).

A tenacidade é considerada uma propriedade mecânica intrínseca de fundamental importância como indicativo da resistência à propagação ou iniciação das fraturas (Atkinson, 1987).

A quantificação da tenacidade à fratura pode ser determinada por ensaios de diversas naturezas, como tração direta e indireta, compressão simples e flexão de vigas. Os primeiros ensaios para avaliar a tenacidade à fratura em rochas tinham como base metodologia padronizada para materiais metálicos (Schimidt, 1976). Esses ensaios apresentavam resultados aceitáveis, contudo demandavam grandes quantidades de corpos de prova com geometrias complicadas em relação à realidade da mecânica de rochas.

Na década de 80, a ISRM - International Society for Rock Mechanics and Rock Engineering - formou um grupo de trabalho, que apresentou sugestões de dois métodos para determinação da tenacidade (ISRM, 1988), correspondendo aos corpos de prova determinados Chevron Bend (CB) e Short Rod (SR). Em 1995, a ISRM sugeriu um terceiro ensaio cujo corpo de prova é chamado de Cracked Chevron Notched Brazilian Disc (CCNDB), que será melhor explicado mais adiante. Vale ressaltar que atualmente existe uma série de outros métodos, não reconhecidos pela ISRM, para determinação da tenacidade à fratura de rochas.

Os ensaios sugeridos pela ISRM têm dois níveis. O nível I é realizado sob controle de carga, enquanto o nível II sob controle de deslocamento da abertura da boca da trinca. Em geral, são usados LVDTs, para medir o deslocamento no ponto 
de carregamento, e extensômetros do tipo "clip gauge", para medir a abertura da boca da trinca.

O nível I requer somente o registro da carga máxima e é de rápida execução, com um tempo máximo de 10 segundos. Considera-se que o ponto de avaliação da tenacidade à fratura ocorre na carga máxima, com o material apresentando um comportamento elástico linear.

As rochas possuem uma zona de processo da fratura na ponta da fissura, por isso o corpo de prova precisa ser suficientemente grande em relação a essa zona, para que a condição de plastificação de pequena escala seja válida. Deste modo a zona terá comportamento elástico linear. $\mathrm{O}$ tamanho da zona de processo de fraturas depende do tamanho dos grãos, portanto o valor obtido pelo ensaio de nível I é válido apenas para corpos de prova grandes com granulação fina. Para outros casos, o ensaio de nível I não produz valores válidos, necessitando também a realização de ensaio de nível II.

O nível II requer registro da carga e do deslocamento durante todo o ensaio, sendo mais lento que o nível I. Os valores fornecidos são mais precisos, porém sua realização é mais complicada e tem custo mais alto. Sob condições não ideais, a tenacidade à fratura pode ocorrer antes ou depois da carga máxima, dessa maneira gerando um resultado errado. O nível II considera esses aspectos em sua análise, de maneira que corrige a tenacidade à fratura em função da não linearidade e não elasticidade do material. Outro aspecto importante é que o nível II não sofre influência do tamanho do corpo de prova.

Como em outros ensaios de engenharia, existe um grande número de fatores que podem interferir nas medições da tenacidade. Destacam-se: dimensões do entalhe, geometria do corpo de prova (efeito escala), anisotropia do material, condições do ambiente, procedimentos durante o ensaio, dentre outros.

\subsubsection{Dimensões do entalhe e geometria do corpo de prova}

As rochas são constituídas por assembleias de diferentes minerais. Cada mineral tem suas respectivas propriedades, sendo a clivagem uma das mais importantes. Trata-se de uma propriedade vetorial dos minerais, a qual consiste em sua capacidade de se fragmentarem segundo planos paralelos entre si. Atkinson \& Meredith (1987) (apud Atkinson, 1987) apresentaram valores médios 
da tenacidade no modo I para feldpato e quartzo. $\mathrm{O}$ resultado obtido para o quartzo foi 6 (seis) vezes maior que o obtido para feldspato. Os autores presumem que isso ocorra em função da clivagem, pois o feldspato possui enquanto o quartzo não.

Por conta destas propriedades dos minerais, o corpo de prova da rocha deve ser representativo e geometrias reduzidas podem apresentar eventuais efeitos de escala, uma vez que a concentração de tensão pode estar limitada a um único grão mineral.

Segundo Whittaker et al. (1992), a dimensão do corpo de prova tem efeitos similares aos da dimensão do entalhe. Ambos subdimensionados produzem valores baixos de tenacidade à fratura.

Nas sugestões de ensaio da ISRM (ISRM, 1988 e 1995), são fornecidas as dimensões possíveis para o corpo de prova e entalhe.

\subsubsection{Anisotropia do material}

Uma das principais diferenças entre as rochas e os outros materiais estudados (como vidros, metais, polímeros, entre outros) são as heterogeneidades e anisotropias. Rochas possuem texturas distintas e estruturas diversas.

Rochas sedimentares possuem acamamentos e laminações produzidas ao longo da deposição do material. Rochas ígneas podem apresentar direções preferenciais de fluxo, formando, assim, planos com concentração de determinado mineral. Em função do metamorfismo, as rochas metamórficas apresentam diversas estruturas, como bandamento gnáissico, xistosidade, entre outras foliações. Microjuntas e fissuras planares também são anisotropias comuns encontradas nas rochas (Whittaker et al., 1992).

Todas essas estruturas e texturas formam planos de fraqueza nas rochas, por exemplo, bandamento gnáissico em um gnaisse cujo protólito seja um granito. $\mathrm{O}$ bandamento trata-se do alinhamento de bandas claras, formadas por quartzos e feldspatos, e bandas escuras, formadas por biotitas. A biotita tem hábito planar e dureza muito menor que o quartzo e o feldspato. A direção paralela ao bandamento apresenta valores mais baixos de tenacidade quando comparada com a direção ortogonal (Whittaker et al., 1992). 
Assim como em outros ensaios, a influência da anisotropia na tenacidade é analisada estudando a resistência em diferentes direções. No ensaio para determinação da tenacidade, o entalhe é feito em diferentes direções, por exemplo, em uma rocha gnáissica, o entalhe pode ser feito nos planos ortogonal, paralelo e inclinado à foliação.

\subsubsection{Efeito do tamanho dos grãos}

A influência do tamanho dos grãos nos materiais cerâmicos foi muito estudada. Em todos os casos, foram observados aumento na tenacidade à fratura com a diminuição da granulometria do material (Singh et al., Rice \& Freiman e Rice et al. apud Whittaker et al., 1992).

Huang \& Wang (1985) explicaram que, quanto maior a granulometria do material, maior será a quantidade de fissuras nos contatos entre os grãos, e maiores serão as fissuras intergranulares. Nas rochas, as fissuras são desenvolvidas intergranularmente (entre os grãos) e intragranularmente (através dos grãos). A quantidade de energia necessária para se criar uma nova superfície entre grãos, em geral, é menor que a energia necessária para se criar uma superfície através dos grãos. Assim, quanto maior a granulometria, maior o contato entre os grãos e menor a energia necessária para que a fissura do material se propague (Almeida, 1999).

Rochas com granulometrias mais grossas apresentam maior concentração de defeitos e falhas que rochas mais finas. Esses defeitos e falhas têm grande influência na tenacidade das fraturas (Atkinson, 1987).

Hashida \& Takahashi (1993) realizaram experimentos em amostras de granito com entalhe. Tais experimentos foram realizados em ciclos de carregamento, e, após cada etapa, foram feitas lâminas petrográficas das rochas. Inicialmente as amostras apresentavam microfissuras isoladas, característica da rocha. Com a progressão do carregamento, houve aumento das microfissuras. Por fim, ocorreu extensão das microfissuras, em função da coalescência delas na zona de comportamento não linear.

Whittaker et al. (1992) destacam que o corpo de prova deve ser no mínimo $10(\mathrm{dez})$ vezes maior que a granulometria da rocha, de forma que o processo de fraturamento ocorra para um conjunto policristalino e não para apenas um 
mineral. Os autores citam, também, que a máxima largura aceitável para o entalhe deve ser maior que os grãos da rocha.

\subsubsection{Efeito do teor de umidade}

Assim como em outras propriedades mecânicas, o teor de água influencia no resultado da tenacidade. $\mathrm{O}$ teor de umidade pode influenciar mecanicamente e/ou quimicamente. Whittaker et al. (1992), a partir de uma série de trabalhos, concluíram que a tenacidade à fratura diminui com o aumento da umidade nas amostras de rochas.

\section{4}

\section{Método cracked chevron notched brazilian disc (CCNDB)}

Inicialmente, esta metodologia de ensaio foi utilizada para determinar a tenacidade à fratura de materiais cerâmicos. $\mathrm{O}$ corpo de prova tem forma de disco brasileiro com entalhe em "chevron", o qual é feito com dois cortes em ambos os lados do disco ao longo do mesmo plano diametral, tendo forma de V.

A área entalhada em forma de $\mathrm{V}$ ou "chevron" gera um período relativamente longo de crescimento estável da fissura sob aumento da carga antes do ponto no qual a tenacidade à fratura é analisada. Esse ponto coincide com a carga máxima em um material frágil e elástico linear.

O ensaio CCNDB é feito sob controle de força e requer somente o registro da carga máxima, avaliando a tenacidade à fratura somente para o nível I. A carga é aplicada paralelamente ao plano do entalhe, portanto gera um carregamento no modo I de propagação da fissura.

A propagação da fissura inicia na extremidade do entalhe e se propaga radialmente na direção externa do corpo de prova. A ISRM (1995) sugere que o carregamento deve ter uma velocidade tal que a ruptura deva ocorrer em, no máximo, 20 (vinte) segundos após o início do ensaio ou em uma taxa de carregamento que não seja inferior à $0,25 \mathrm{MPa} \sqrt{\mathrm{m}} /$ segundo .

A tenacidade à fratura $\left(\mathrm{K}_{\mathrm{IC}}\right)$ deve ser calculada através da equação 2.19. Pode ser obtida, também, através de soluções semianalíticas ou numéricas utilizando métodos de elementos finitos ou elementos discretos. Diferente de 
outros ensaios sugeridos pela ISRM, em que a análise do problema é mais simples, o CCNDB representa um problema 3D.

$$
K_{I C}=\frac{P_{\max }}{B \sqrt{D}} Y_{\min }^{*}
$$

Onde:

$P_{\max }$ - força máxima aplicada;

$B$ - espessura do corpo de prova;

$D$ - diâmetro do corpo de prova;

$Y_{\min }^{*}$ - valor crítico (mínimo) do fator de intensidade de tensão adimensional para o corpo de prova.

$Y_{\min }^{*}$ é determinado em função das dimensões geométricas $\alpha_{0}, \alpha_{1}$ e $\alpha_{B}$ do corpo de prova (figura 2.7), conforme a expressão abaixo:

$$
Y_{\min }^{*}=u e^{v \alpha_{1}}
$$

\section{Onde:}

$u$ e $v$ - são constantes tabeladas na sugestão da ISRM (1995) e determinados em função de $\alpha_{0}$ e $\alpha_{B}$.

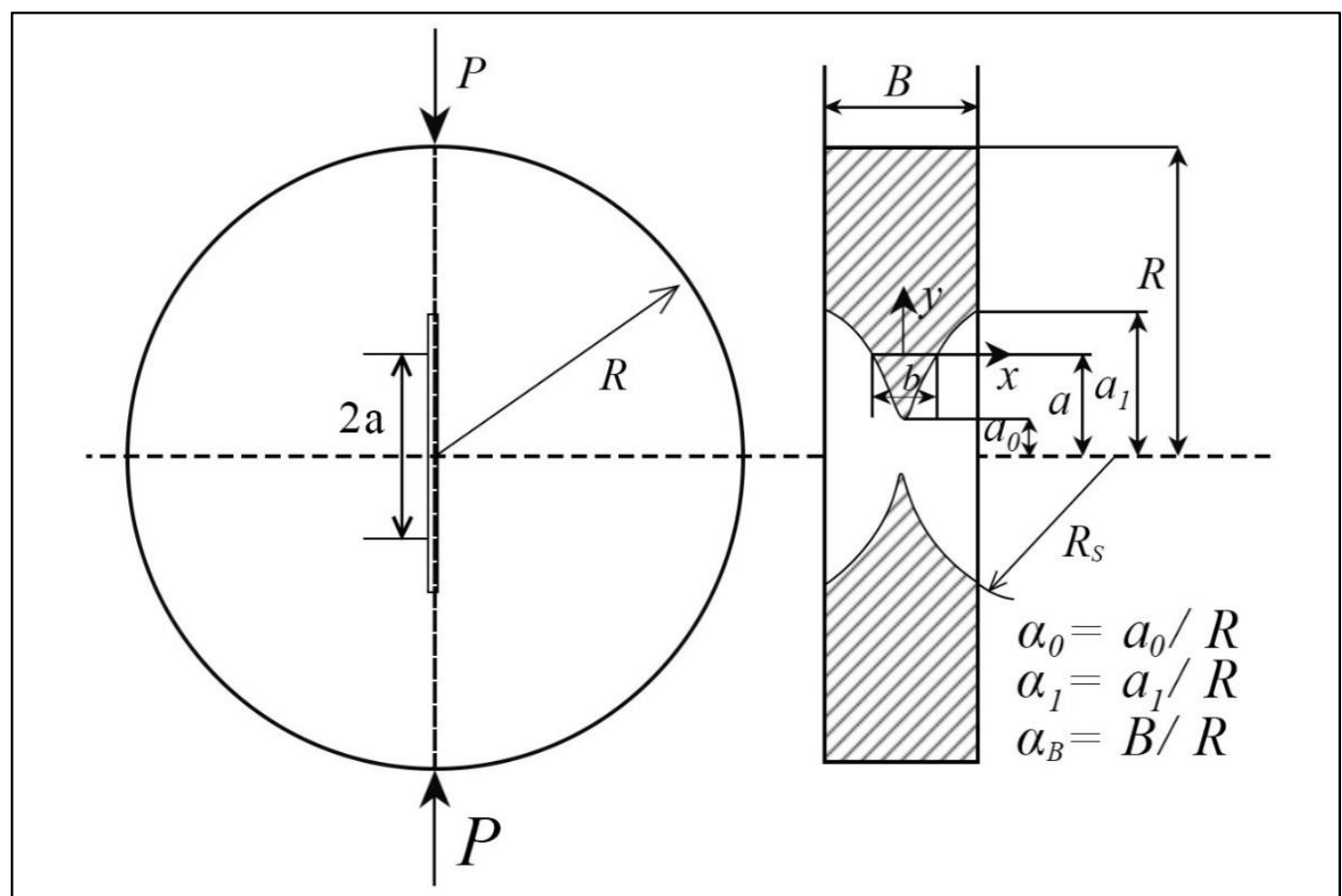

Figura 2.7 - Geometria do corpo de prova para o método CCNDB (forma de disco brasileiro com entalhe em "chevron" - Wang et al., 2003). 
Uma importante característica do ensaio CCNDB é o fator de intensidade de tensão adimensional ter um valor mínimo durante o ensaio. O $Y_{\min }^{*}$ é um parâmetro de cálculo importante que afeta a exatidão dos ensaios de tenacidade à fratura. Em geral, é determinado por análise numérica. Antes dessa metodologia sugerida pela ISRM (1995), Chen (1990) e Xu \& Fowell (1994) utilizaram o método dos elementos de contorno.

Na ISRM (1995), foi fornecida uma geometria padrão, apresentada na tabela 2.1 , onde foi dado o valor do respectivo fator adimensional correspondente ao corpo de prova de 75 milímetros de diâmetro.

Tabela 2.1 - Dimensões geométricas padrão para corpos de prova CCNDB sugeridas pela ISRM (ISRM, 1995).

\begin{tabular}{lc}
\multicolumn{1}{c}{ Descrição } & Dimensões \\
\hline Diâmetro (D) & $75,00 \mathrm{~mm}$ \\
Espessura (B) & $30,00 \mathrm{~mm}$ \\
Comprimento inicial do entalhe em “chevron" $\left(a_{0}\right)$ & $9,89 \mathrm{~mm}$ \\
Comprimento final do entalhe em “chevron" $\left(a_{1}\right)$ & $24,37 \mathrm{~mm}$ \\
Diâmetro da Serra $\left(\mathrm{D}_{\mathrm{s}}\right)$ & $52,00 \mathrm{~mm}$ \\
Profundidade do Corte $\left(\mathrm{h}_{\mathrm{c}}\right)$ & $16,95 \mathrm{~mm}$ \\
$Y_{\text {min }}^{*}$ (adimensional) & 0,84 \\
$\alpha_{0}$ (adimensional) & 0,2637 \\
$\alpha_{1}$ (adimensional) & 0,6500 \\
$\alpha_{B}$ (adimensional) & 0,6933 \\
\hline
\end{tabular}

Wang (1998) mostrou que os valores de $Y_{\text {min }}^{*}$, obtidos anteriormente, não apresentaram exatidão adequada. Valores obtidos por Chen (1990) foram superestimados, enquanto os resultados de Xu \& Fowell (1994) e ISRM (1995) foram subestimados. Wang et al. (2003) obtiveram, através de elementos finitos, um valor, segundo os autores, mais exato $\left(Y_{\min }^{*}=0,943\right)$.

Wang et al. (2004) propuseram novo método baseado em Bluhm (1975) apud Pehovaz-Alvarez (2004). Esse novo método foi validado após comparação por métodos numéricos de elementos finitos e de elementos de contorno. 
Santos (2004) realizou um estudo da tenacidade à fratura de gnaisses facoidais na cidade do Rio Janeiro. A autora verificou que o aumento do intemperismo pode ser considerado um mecanismo de redução da tenacidade para a rocha estudada, constituindo um mecanismo de pré-ruptura de maciços rochosos, ocasionando quedas de blocos.

Almeida et al. (2006) realizaram uma caracterização mecânica de rochas graníticas na cidade do Rio de Janeiro. Foram realizados ensaios CCNDB para determinação da tenacidade à fratura. Os autores identificaram nas rochas anisotropia originada da estrutura de fluxo ígneo. Dessa maneira, determinaram 3 (três) direções do entalhe em relação aos planos identificados. Os resultados obtidos coincidiram com os padrões conhecidos, onde o plano paralelo à orientação identificada gerou os valores mais baixos de $\mathrm{K}_{\mathrm{IC}}$, enquanto o plano perpendicular gerou valores mais altos.

Em 2014, a ISRM propôs uma nova opção de metodologia para determinação da tenacidade à fratura no modo I utilizando amostras semicirculares - Semi-Circular Bend Specimen (Kuruppu et al., 2014). O corpo de prova semicircular tem um pequeno entalhe no centro, que é ortogonal ao diâmetro. É submetida a compressão em três pontos até a falha. A partir da carga aplicada e das dimensões do corpo de prova, é possível determinar a tenacidade à fratura.

Ghamgosar et al. (2015) apresentaram um estudo sobre o efeito da anisotropia na tenacidade à fratura de arenitos laminados. Os resultados obtidos apresentaram uma influência inesperada das rochas. A tenacidade à fratura aumentou à medida que o ângulo de foliação também aumentava de $0^{\circ}$ a $45^{\circ}$, sendo essa direção a que atingiu os maiores valores. E entre $45^{\circ}$ e $90^{\circ}$ houve uma diminuição da tenacidade à fratura, sendo $90^{\circ}$ a direção mais baixa. Os autores observaram padrões de extensão da fratura onde se mostrava que o aumento do ângulo da foliação alterou a direção de propagação da fissura no entalhe, acompanhada por uma mudança do modo de ruptura, do tipo I para o tipo misto I e II.

Feng et al. (2017) analisaram a influência da temperatura na tenacidade à fratura no modo I, utilizando o ensaio SCB (semicircular bend) em arenitos. As rochas foram expostas a temperaturas entre 20 e $800^{\circ} \mathrm{C}$. As rochas foram afetadas, mas não apresentaram um padrão consistente de aumento ou decréscimo da 
tenacidade relacionada com o aumento da temperatura. Os autores dividiram as temperaturas em 3 estágios. No estágio de baixa temperatura $\left(20\right.$ a $\left.100^{\circ} \mathrm{C}\right)$, a tenacidade à fratura aumenta lentamente. No estágio de temperatura média (100 a $\left.500^{\circ} \mathrm{C}\right)$, ela cai lentamente. Já na alta temperatura $\left(500\right.$ a $\left.800^{\circ} \mathrm{C}\right)$, ela diminui significativamente.

Wang et al. (2017) apresentaram um estudo experimental da tenacidade à fratura no modo I de folhelhos estratificados. Os autores concluíram que a propriedade analisada é altamente sensível à direção da estratificação. Foram obtidos os menores valores de $\mathrm{K}_{\mathrm{IC}}$ quando o carregamento é aplicado paralelamente ao plano da estratificação. Enquanto os maiores valores são encontrados quando o carregamento é aplicado ortogonalmente ao plano estratificação.

Guha Roy et al. (2017) realizaram uma revisão das correlações existentes e propuseram, quando acharam necessário, novas relações da tenacidade à fratura no modo I com propriedades físicas e mecânicas. Os autores utilizaram dois litotipos na análise experimental: rochas sedimentares e rochas cristalinas. Foram obtidas diversas relações da tenacidade à fratura das rochas com a resistência à compressão simples, resistência à tração, densidade e velocidade de ondas. Os autores identificaram limitações nas relações para baixos valores de resistência e reiteraram cautela nas aplicações das correlações, pois existe uma série de características e propriedades das rochas que influenciam na sua resistência, como contato dos grãos, textura, porosidade, dentre outros.

Vale salientar que, em vista do emprego desse ensaio na presente pesquisa, maiores detalhes em relação à metodologia serão apresentados no Capítulo 3, que corresponde aos Materiais e Métodos utilizados. 


\section{3 \\ Materiais e métodos}

Este capítulo apresenta os materiais utilizados neste trabalho e as etapas experimentais, discriminando as normas técnicas seguidas e os equipamentos envolvidos.

\section{1 Materiais}

Para o estudo e a análise do comportamento da tenacidade para diferentes níveis de alterações, foram coletados 10 (dez) blocos, sendo 5 (cinco) de rocha sã, 3 (três) de rocha medianamente alterada e 2 (dois) de rocha alterada. Foram realizadas diversas visitas ao longo de grande parte da pedreira, onde foram identificados os pontos de coleta. A pequena quantidade de blocos de rochas alteradas e medianamente alteradas foi devido à dificuldade de sua localização na pedreira e à fragilidade das rochas. As rochas alteradas, além de apresentarem baixa resistência, eram muito friáveis e quebravam com facilidade. Ao longo do processo de amostragem e preparação dos corpos de prova, muito material de rochas alteradas foi perdido.

As rochas sãs foram retiradas diretamente da frente de produção (figura 3.1). Já as rochas medianamente alteradas e alteradas foram retiradas de outros locais, à meia encosta, respeitando sempre a litologia do material escolhido, que será discutida mais adiante.

A retirada dos blocos foi realizada com o auxílio dos funcionários da pedreira. Foram utilizadas duas retroescavadeiras, uma com concha e outra com rompedor hidráulico acoplado (figuras 3.2 e 3.3). Após a coleta, os blocos foram transportados por meio de caminhão munck, e acondicionados no Laboratório de Estruturas e Materiais da PUC-Rio, onde foram retirados os corpos de provas. 


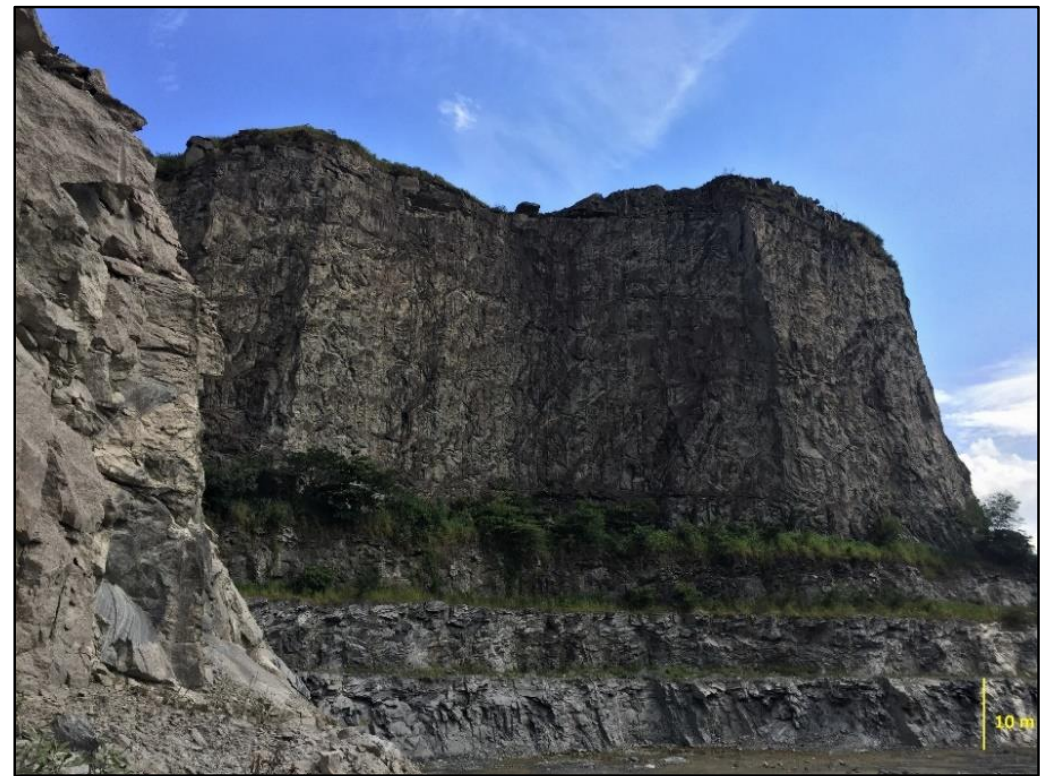

Figura 3.1 - Frente de produção da Pedreira Bangu, local de coleta dos blocos de rocha sã.

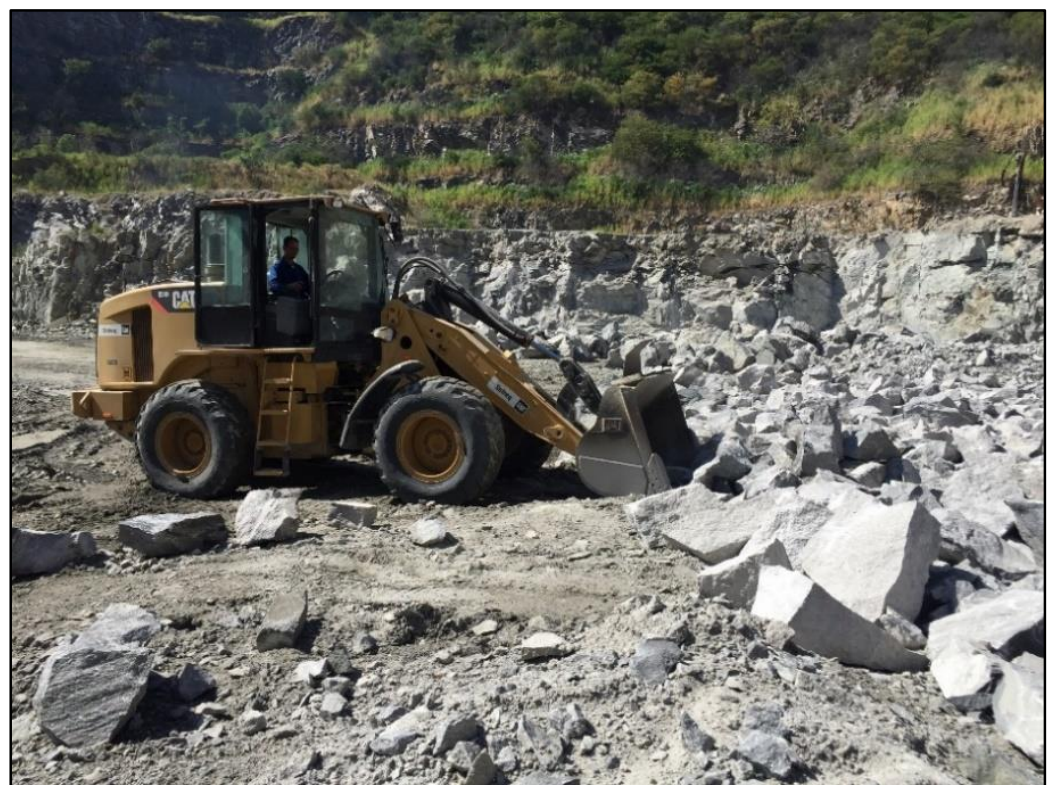

Figura 3.2 - Retroescavadeira com concha auxiliando na retirada dos blocos.

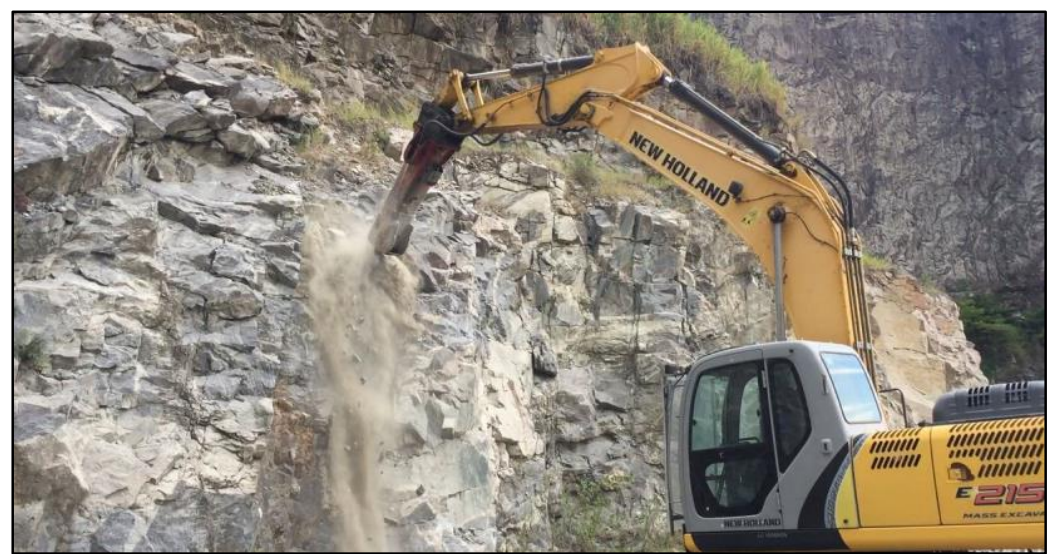

Figura 3.3 - Retroescavadeira com rompedor hidráulico auxiliando na retirada de blocos. 
A individualização dos blocos quanto à sua alteração foi realizada por descrição macroscópica com base na Sugestão para Classificação e Descrição de Maciços Rochosos da ISRM (ISRM, 2007 apud Marques, 2010) (tabela 3.1).

Tabela 3.1 - Sugestão da ISRM (2007 apud Marques, 2010) para classificação e descrição de maciços rochosos (traduzido).

\begin{tabular}{|c|c|c|}
\hline Grau de Alteração & Descrição & Classe \\
\hline Rocha Sã (SR) & $\begin{array}{l}\text { Nenhum sinal visível de intemperismo na matriz, } \\
\text { podendo haver alguma descoloração ao longo das } \\
\text { descontinuidades. }\end{array}$ & I \\
\hline $\begin{array}{l}\text { Rocha } \\
\text { Levemente } \\
\text { Alterada (SW) }\end{array}$ & $\begin{array}{l}\text { Descoloração na rocha indicando início de } \\
\text { intemperismo na matriz e ao longo da superfície das } \\
\text { descontinuidades. Toda a matriz pode estar descolorida } \\
\text { pelo intemperismo e pode estar, externamente, } \\
\text { levemente descolorida (capa de alteração). }\end{array}$ & II \\
\hline $\begin{array}{l}\text { Rocha } \\
\text { Medianamente } \\
\text { Alterada (MW) }\end{array}$ & $\begin{array}{l}\text { Menos da metade da matriz da rocha está decomposta } \\
\text { ou desintegrada à condição de solo. Tem presença de } \\
\text { partes sãs e descoloridas formando descontinuidades } \\
\text { ou enclaves. }\end{array}$ & III \\
\hline $\begin{array}{l}\text { Rocha Muito } \\
\text { Alterada (HW) }\end{array}$ & $\begin{array}{l}\text { Mais da metade da matriz da rocha está decomposta ou } \\
\text { desintegrada à condição de solo. Tem presença de } \\
\text { rocha sã ou está descolorida formando zonas de } \\
\text { descontinuidades ou enclaves. }\end{array}$ & IV \\
\hline $\begin{array}{l}\text { Rocha } \\
\text { Completamente } \\
\text { Alterada }(\mathrm{CW})\end{array}$ & $\begin{array}{l}\text { Toda a matriz da rocha está decomposta ou } \\
\text { desintegrada à condição de solo. Estruturas da rocha } \\
\text { são comumente preservadas. }\end{array}$ & $\mathrm{V}$ \\
\hline $\begin{array}{l}\text { Solo Residual } \\
\text { (RS) }\end{array}$ & $\begin{array}{l}\text { Toda a rocha foi transformada em solo. Não apresenta } \\
\text { mais estruturas geológicas da rocha. Existe grande } \\
\text { variação de volume, mas não tem nenhum indício de } \\
\text { solo transportado. }\end{array}$ & VI \\
\hline
\end{tabular}

Posteriormente os graus de alteração foram confirmados após análise de lâminas petrográficas e difração de raio X. Na rocha sã (classe I), os cristais se mostravam preservados e não havia sinal visível de intemperismo na matriz. $\mathrm{Na}$ rocha medianamente alterada (classe III), os grãos de feldspato apresentavam menor brilho quando comparados com as rochas sãs. As rochas alteradas (classe 
IV) apresentavam menor coesão, com grãos mais alterados, e os feldspatos passaram a ter tons mais castanhos ou amarelados (figura 3.4).

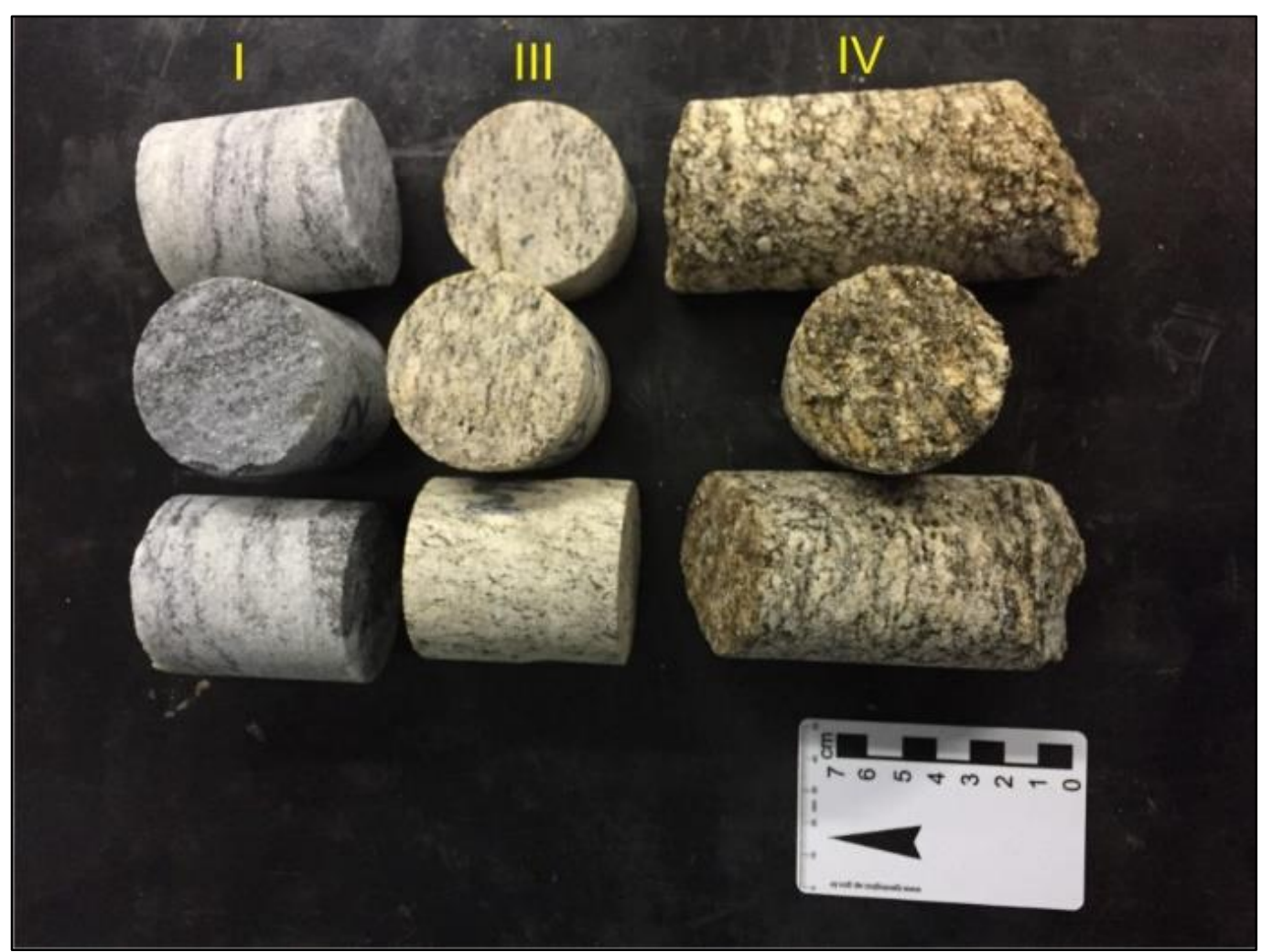

Figura 3.4 - Litotipos estudados (I. rocha sã, III. rocha medianamente alterada, IV. rocha alterada).

O grau de alteração observado nas rochas é fruto do intemperismo. Barroso (1993) define intemperismo como a alteração secundária ou meteórica que se desenvolve na superfície ou próximo dela, portanto, em condições de baixas pressão e temperatura, diferentes da conjuntura em que as rochas estavam condicionadas às porções mais internas da crosta. $\mathrm{O}$ intemperismo é dividido em três tipos: físico, químico e biológico.

Segundo Marques (1998) apud Santos (2004), o intemperismo físico, também chamado de desagregação física, é um processo que causa fragmentação in situ do arcabouço de uma rocha sem que haja qualquer mudança na composição química. Os agentes causadores de intemperismo físico são: variações de temperaturas, alívio de tensões, congelamento de água nas fissuras das rochas, umedecimento e secagem, dentre outros.

O intemperismo químico promove a decomposição química dos minerais que constituem as rochas, transformando-os em minerais secundários, podendo 
ser estáveis ou não. O principal agente causador é a água da chuva. Os processos de decomposição química mais importantes são oxidação/redução e solução.

Barroso (1993) menciona que o intemperismo biológico produz uma combinação de desagregação e decomposição através de agentes orgânicos (fauna e flora), cuja ação é mais relevante nos horizontes de solo.

No presente trabalho, o intemperismo não será abordado de maneira distinta (intemperismo físico, químico ou biológico). Serão tratados apenas os graus de alteração das rochas estudadas.

\subsubsection{Contexto geológico da área}

No município do Rio de Janeiro, ocorrem regionalmente gnaisses e migmatitos de composições e estruturas variadas, além de granitóides e diques de composição básica e alcalina que os intrudem. São subdivididos em duas séries distintas: Série Inferior, ortognássica, e Série Superiror, paragnássica (Helmbold et al., 1965).

O Morro do Sandá está localizado ao norte do Maciço da Pedra Branca. As rochas gnáissicas e migmatíticas correspondem aos litotipos encaixantes e pertencem à denominada Série Inferior (Helmbold et al., 1965). São rochas gnaissificadas de composição que variam desde quartzo dioríticas até os tipos granodioríticos, com predominância de tipos tonalíticos. Na sua maioria, são rochas fortemente bandadas, intensamente deformadas, com dobras muito apertadas e planos de cisalhamento associados, com diferentes granulometrias e texturas. Em geral, não apresentam granada ou outro mineral metamórfico relevante. Em nível de afloramento, as rochas gnáissicas possuem aspecto migmatítico. É comum a preservação de enclaves que denotam relações temporais que podem ser definidas no campo. Essas rochas ocupam a base da unidade ortoderivada (Porto Jr, 2004).

Há também ocorrência, de forma mais restrita, de gnaisses graníticos, sendo leucocráticos com foliação marcada pela alternância do alinhamento de grãos de biotita e grãos de microclima em conjunto com quartzo.

$\mathrm{Na}$ área, ocorrem também rochas intrusivas ácidas (graníticas), comuns no município do Rio de Janeiro, sob diversas texturas e estruturas. O granitóide de 
maior distribuição superficial é o Granito Pedra Branca (Porto Jr \& Valente, 1988).

O Granito Pedra Branca possui uma notável estrutura planar e/ou linear, com mergulhos variáveis. É uma rocha leucocrática, inequigranularhipidiomórfica, porfirítica, com granulometria variando de fina a grossa. É caracterizado pela abundância de megacristais de microclima. Observações de campo indicam que essa estrutura é originada pelo fluxo ígneo durante o regime de intrusão e resfriamento, e não por imposição de esforços tectônicos, sendo, portanto, estruturas primárias.

A intrusão é do tipo forçada, arrancando xenólitos angulosos próximos ao contato. O plúton granítico forma uma zona de contato com as encaixantes, com a intrusão subconcordante de apófises a partir do plúton principal, segundo a foliação gnáissica geral (Nogueira, 2006).

Outro granito que ocorre no Morro no Sandá é o Granito Favela (Pires et al., 1982). Esse possui características distintas do granito Pedra Branca. Trata-se de um biotita granito debilmente foliado, leucocrático, com textura inequigranular hipidiomórfica. São intrusões tabulares, discordantes com a foliação gnáissica, que cortam o Granito Pedra Branca e os veios apolíticos e pegmatíticos a ele relacionados, sendo assim um granito mais jovem.

A intrusão tabular do Granito Favela no Morro do Sandá é subhorizontal, desloca pouco os gnaisses encaixantes e concentra xenólitos angulosos nas margens do dique. Esse granito possui contatos bruscos em relação às encaixantes gnáissicas e complexa geometria, com inflexões abruptas e acunhamentos, com apófises mais verticalizadas (Nogueira, 2006).

\subsubsection{Descrição macroscópica das rochas}

Todos os blocos selecionados são de rochas encaixantes do Morro do Sandá. Como mencionado anteriormente, são rochas gnáissicas que variam de composição quartzo dioríticas até granodioríticas. Essa variação é dada em função da porcentagem de álcali feldspatos no total de feldspatos. $\mathrm{O}$ quartzo diorito tem menos de $10 \%$, e o granodiorito tem entre $60 \%$ e $40 \%$ (classificação de Nockolds, 1954, modificada por Helmbold, 1964 e Porto Jr., 1994). São rochas fortemente bandadas e muito deformadas, apresentando diversas texturas migmatíticas. 


\section{Rochas sãs}

São rochas de cor cinza, mesocráticas, equigranulares com granulação fina. Apresentam texturas lepidoblástica e granoblástica, com bandamento gnáissico bem marcado. Não apresentavam nenhum sinal de alteração. Têm sua composição dada por: quartzo, plagioclásio, biotita e hornblenda.

O quartzo é incolor, com hábito granular, grãos anédricos e granulação fina. O plagioclásio tem cor natural cinza, hábito tabular, grãos euédricos de granulação fina. A biotita tem cor preta, hábito lamelar, granulação fina, sendo o mineral que define a textura lepidoblástica. A hornblenda tem cor preta, hábito blocoso com granulação fina.

\section{Rochas medianamente alteradas}

As rochas medianamente alteradas apresentam cor natural castanho claro, são leucocráticas, inequigranulares, com granulação variando de fina a média. Têm textura nematoblástica e lepidoblástica. $\mathrm{O}$ bandamento gnáissico não é tão bem marcado quando comparado com as rochas sãs. São rochas que apresentam alguns sinais de alteração. Os minerais perderam o brilho, e alguns grãos se desagregam com certa facilidade nas extremidades das amostras. A composição mineralógica é dada por plagioclásio, quartzo, microclima e biotita.

O plagioclásio tem cor castanho, hábito tabular, opaco, grãos euédricos a subédricos, com granulação fina a média. O quartzo é incolor, com hábito granular, grãos anédricos, com granulação fina a média. A microclina tem cor castanho, com hábito tabular a prismático, opaca, com grãos euédricos e granulação fina. A biotita tem cor preta, hábito lamelar e granulação fina.

\section{Rochas alteradas}

As rochas alteradas têm cor natural castanho, índice de cor leucocrática, inequigranulares, com granulação fina a média. Apresenta textura lepidoblástica com o bandamento gnáissico bem marcado. As rochas estão alteradas, friáveis, uma vez que os minerais perderam o brilho e apresentam-se com muitas fraturas. A composição mineralógica é dada por plagioclásio, quartzo, microclina e biotita.

O plagioclásio possui cor castanho, opaco, hábito tabular, grãos euédricos a subédricos, com granulação fina a média. O quartzo é incolor, com hábito granular, grãos anédricos, com granulação fina a média. A microclina é castanha, 
com hábito tabular a prismático, opaca, com grãos euédricos e granulação fina. A biotita é preta, com hábito lamelar e granulação fina.

\subsubsection{Preparação dos corpos de prova}

A preparação dos corpos de prova pode ser dividida em três fases: extração de testemunhos, corte dos corpos de prova e acabamento final. Todas essas etapas foram realizadas no Laboratório de Estruturas e Materiais da PUC-Rio.

$\mathrm{Na}$ primeira fase, foram extraídos testemunhos cilíndricos dos respectivos blocos. Foi utilizado o sistema de perfuração diamantado de alta resistência da marca Hilti, perfuratriz modelo DD 200 e coroas diamantadas com diâmetros internos de $54 \mathrm{~mm}$ e $75 \mathrm{~mm}$ (figura 3.5).

Como as rochas alteradas são muito friáveis, para que os testemunhos fossem retirados, foram confeccionadas duas caixas de consolidação. Caixas de madeira (compensado naval de $20 \mathrm{~mm}$ de espessura), preenchidas por argamassa de cimento (razão 1/1 com cimento de alta resistência CPV) (figura 3.6).

$\mathrm{Na}$ segunda fase, os testemunhos foram cortados nos tamanhos indicados nas sugestões da ISRM dos respectivos ensaios. Em virtude do diâmetro, foi necessária a utilização de duas serras de bancada. A primeira da marca Arotec, cortadora metalográfica modelo Arocor 80 , foi utilizada para o corte de testemunhos com $54 \mathrm{~mm}$ de diâmetro (figura 3.7). Para os corpos de prova extraídos com $75 \mathrm{~mm}$, foi utilizada a serra de bancada da marca Coretest, modelo RCSS-415 Radial Core Slab Saw. Em função da pouca espessura $(30 \mathrm{~mm})$ do corpo de prova para o ensaio CCNDB, foi necessária a utilização de um suporte para segurar o testemunho. Para suprir tal necessidade, foi confeccionado um suporte bipartido em material teflon no Laboratório de Mecânica da PUC-Rio (figura 3.8). 


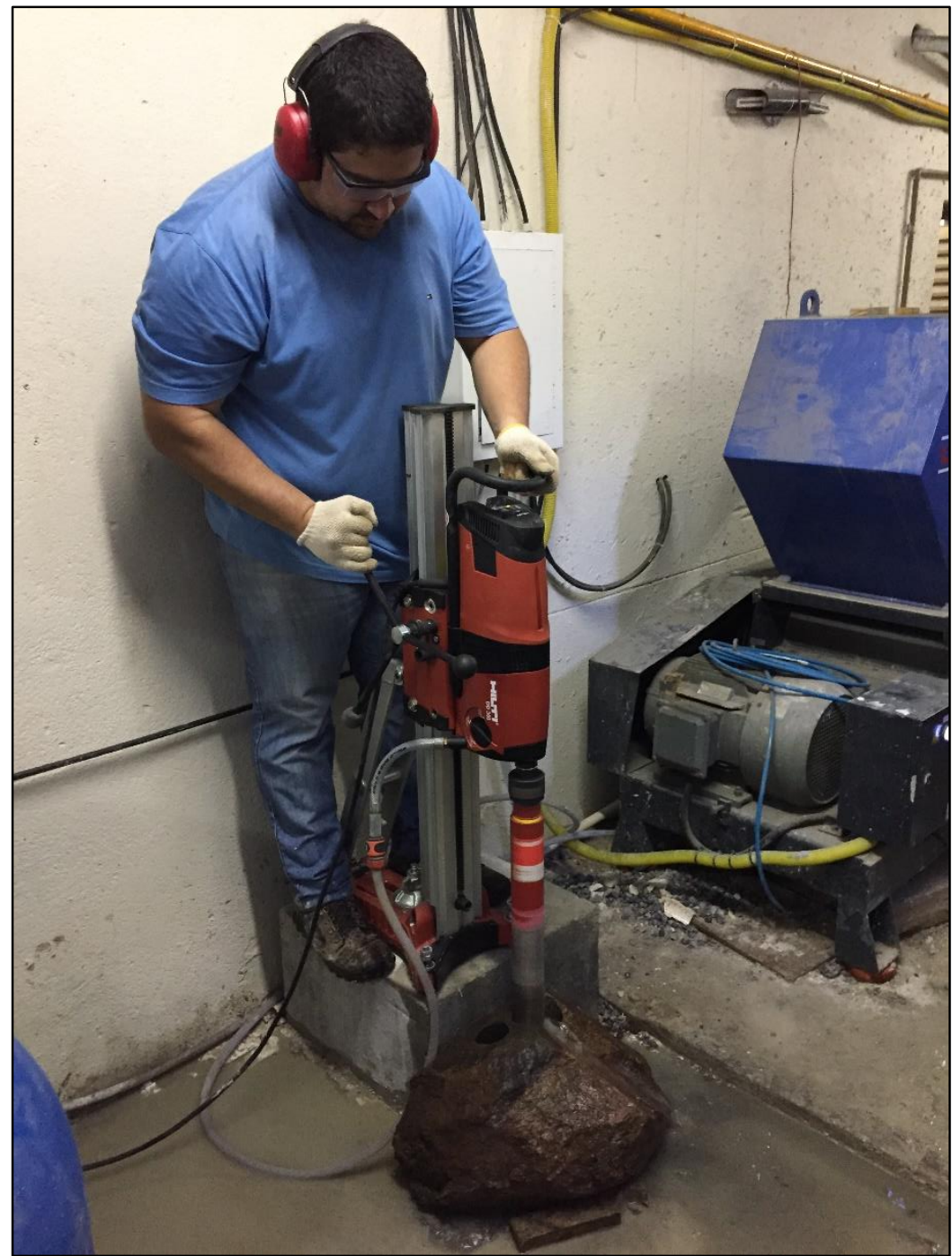

Figura 3.5 - Extração de testemunhos utilizando a perfuratriz da marca Hilti, modelo DD 200.

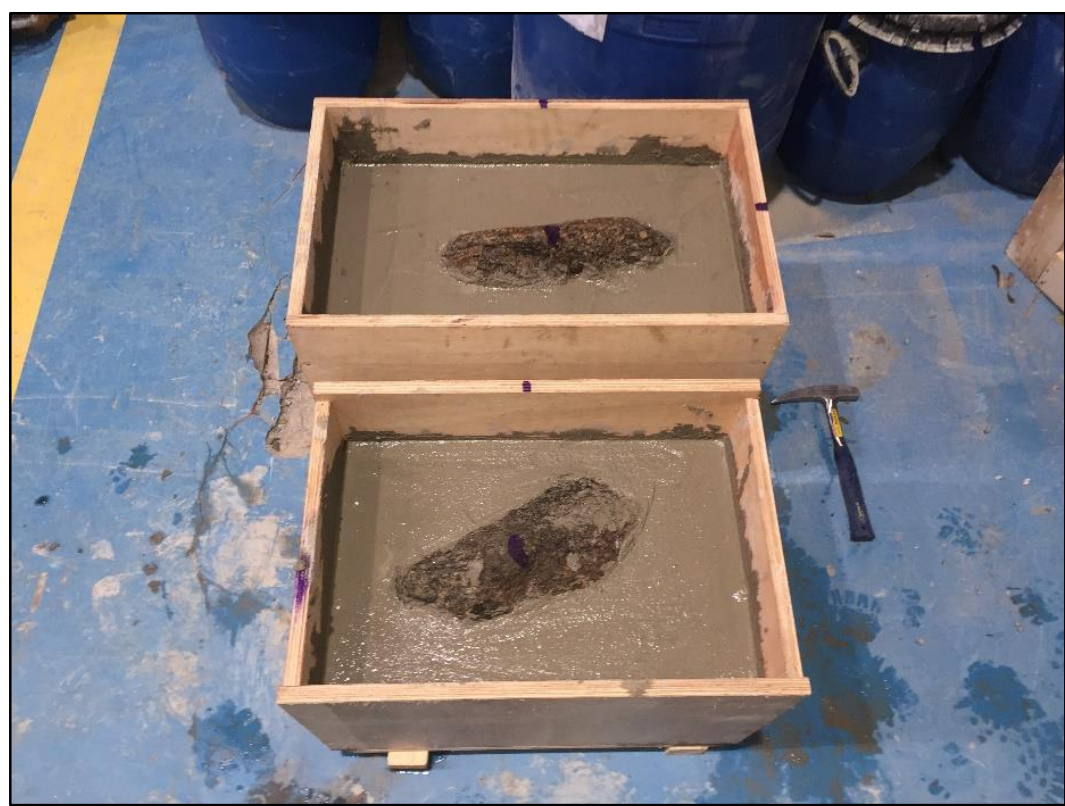

Figura 3.6 - Caixa de consolidação para extração de corpos de prova de rocha alterada. 


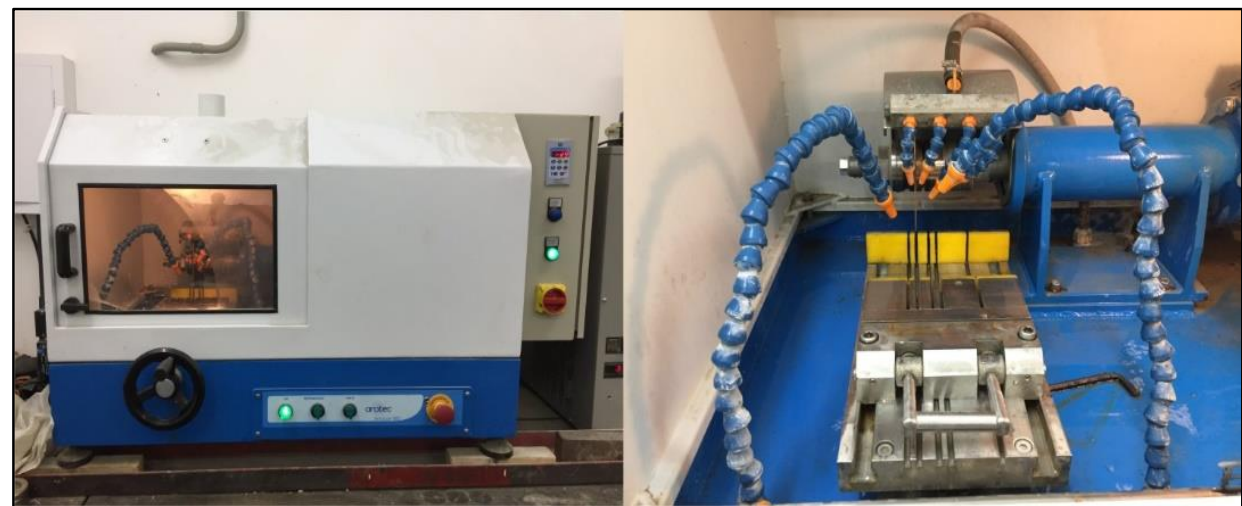

Figura 3.7 - Cortadora metalográfica, utilizada para cortar corpos de prova com $54 \mathrm{~mm}$ de diâmetro.

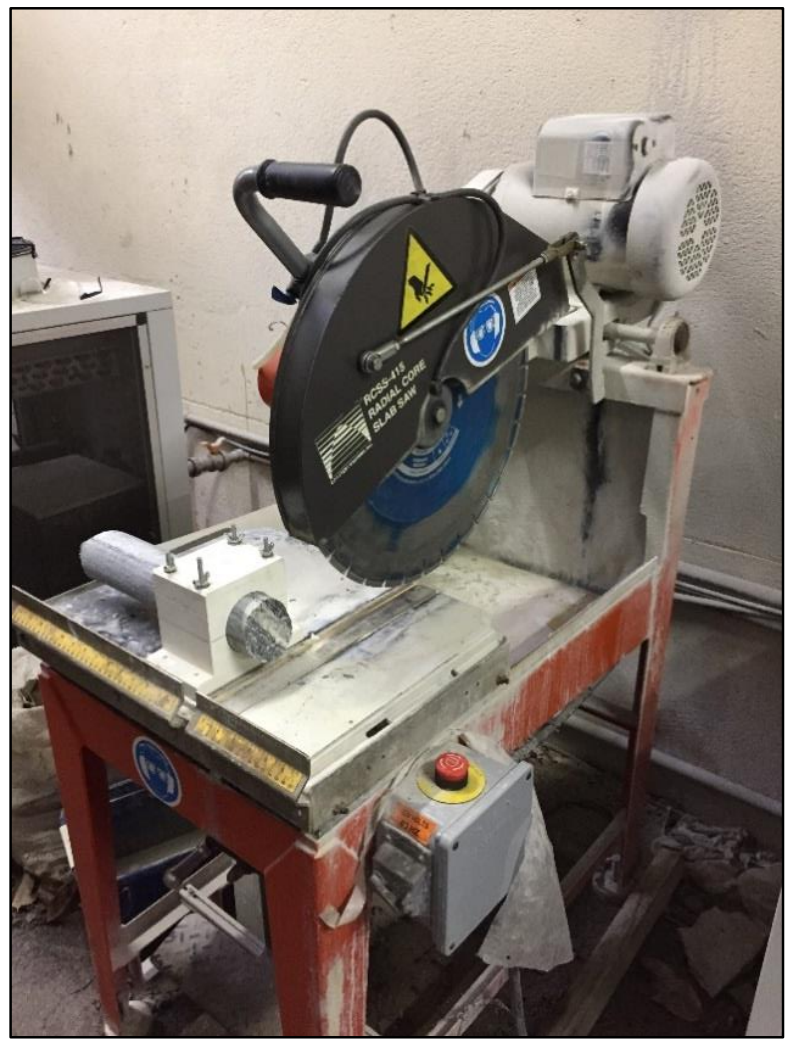

Figura 3.8 - Serra de bancada e suporte bipartido para testemunhos com $75 \mathrm{~mm}$ de diâmetro.

$\mathrm{Na}$ terceira fase, foi realizado o acabamento final dos corpos de prova, onde topo e base foram faceados. Foi utilizada a Retífica Automática para Corpo de Provas da marca Setor Indústria, modelo SET 1000 (figura 3.9). Novamente, em função da geometria do corpo de prova do ensaio CCNDB, foi necessária a confecção de um suporte para segurar e manter a estabilidade do corpo ao facear. Assim, foi confeccionado outro suporte cilíndrico bipartido em teflon, também no Laboratório de Mecânica da PUC-Rio (figura 3.10). 


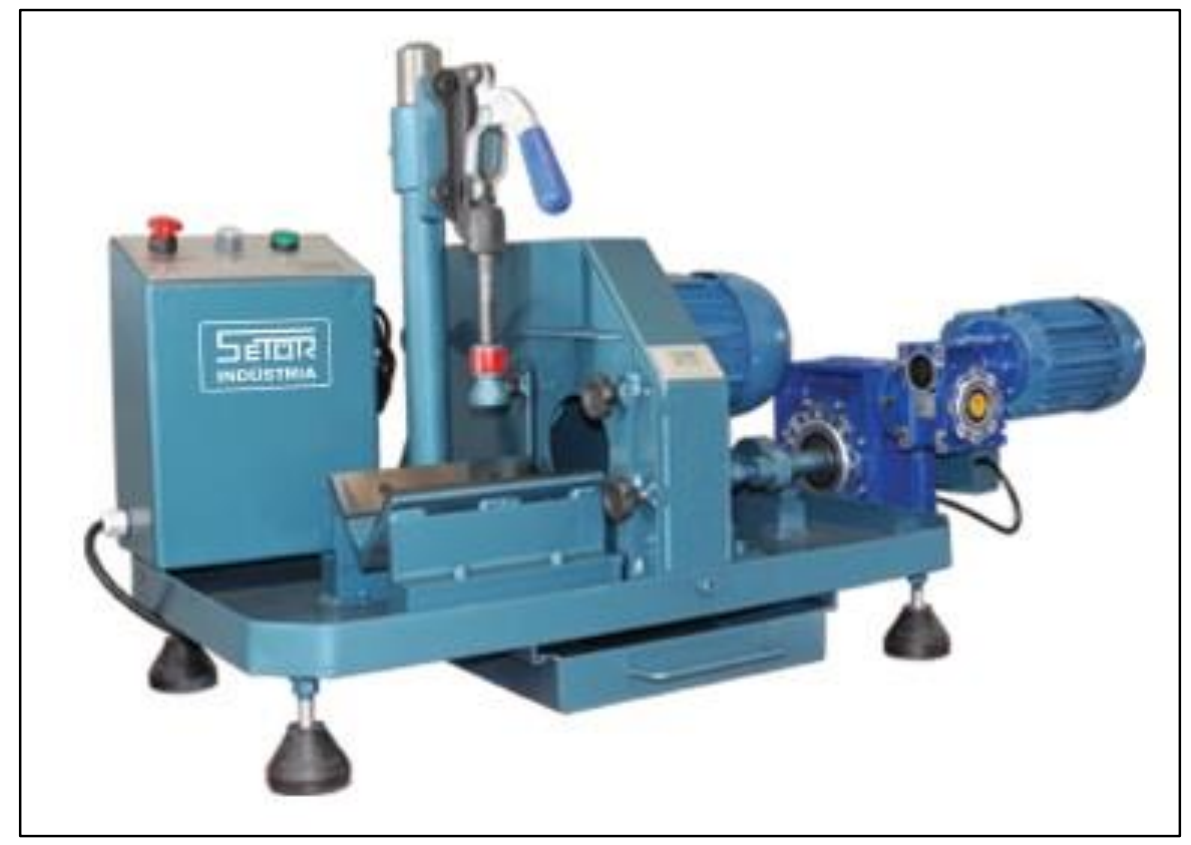

Figura 3.9 - Retífica automática de corpos de prova utilizada para facear topo e base de todos os corpos de prova.

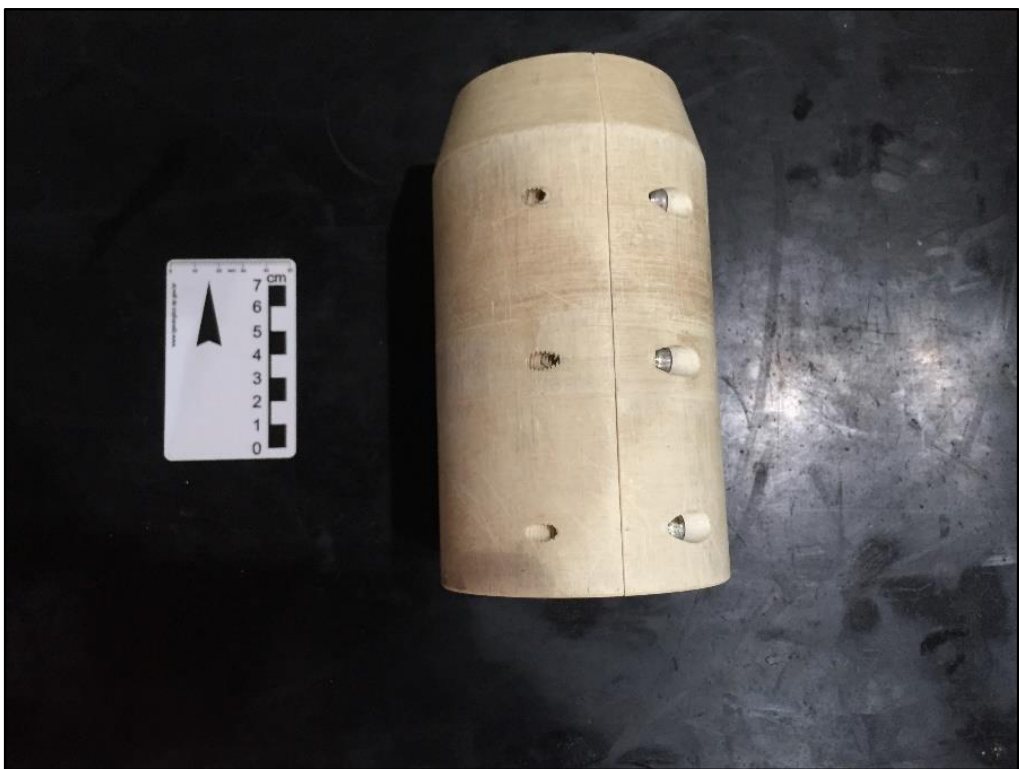

Figura 3.10 - Suporte bipartido confeccionado para auxiliar o faceamento dos corpos de prova CCNDB.

\section{2 Metodologia}

A metodologia do trabalho envolve as seguintes etapas de caracterização do material: química, mineralógica, textural e mecânica, fatores esses fundamentais para o estudo das propriedades e do comportamento geotécnico dos maciços rochosos. Envolve, também, etapas técnicas específicas, como a determinação da 
resistência à tração e da resistência da tenacidade à fratura da rocha. Todos os ensaios de resistência foram realizados com as amostras secas naturalmente ao ar.

A grande maioria dos ensaios foram realizados nos laboratórios de Estruturas e Materiais e de Geotecnia e Meio Ambiente, ambos do Departamento de Engenharia Civil e Ambiental da PUC-Rio.

\subsubsection{Análise petrográfica}

Amostras de mão foram enviadas para o laboratório de laminação da Departamento de Geologia da Universidade Federal do Rio de Janeiro (UFRJ) para a confecção de lâminas petrográficas. Ao todo, foram confeccionadas 6 (seis) lâminas, 2 (duas) para cada grau de alteração, sendo uma na direção ortogonal à foliação e a outra inclinada à foliação (aproximadamente $45^{\circ}$ ).

As lâminas foram analisadas através de microscópio óptico com luz polarizada da marca Olympus, modelo CX31, com câmera (SC-30) acoplada para geração de imagens no Laboratório de Geotecnia e Meio Ambiente da PUC-Rio (figura 3.11).

Foram feitos mosaicos das lâminas com e sem luz polarizada. Para aquisição das imagens, foi utilizado outro modelo de microscópio óptico computadorizado: o Zeiss Axioplan 2ie, com câmera digital Zeiss AxioCam HR (resolução de 1292 x 968 pixels e quantização de 8 bits), do Laboratório de Microscopia Digital do Departamento de Engenharia Química e de Materiais da PUC-Rio (figura 3.12).

O equipamento está automatizado com o software AxioVision 4. O PADI foi desenvolvido com os softwares ks400 (Carl Zeiss Vision, 2004) e AxioVision 4 (Carl Zeiss Vision, 2004). 


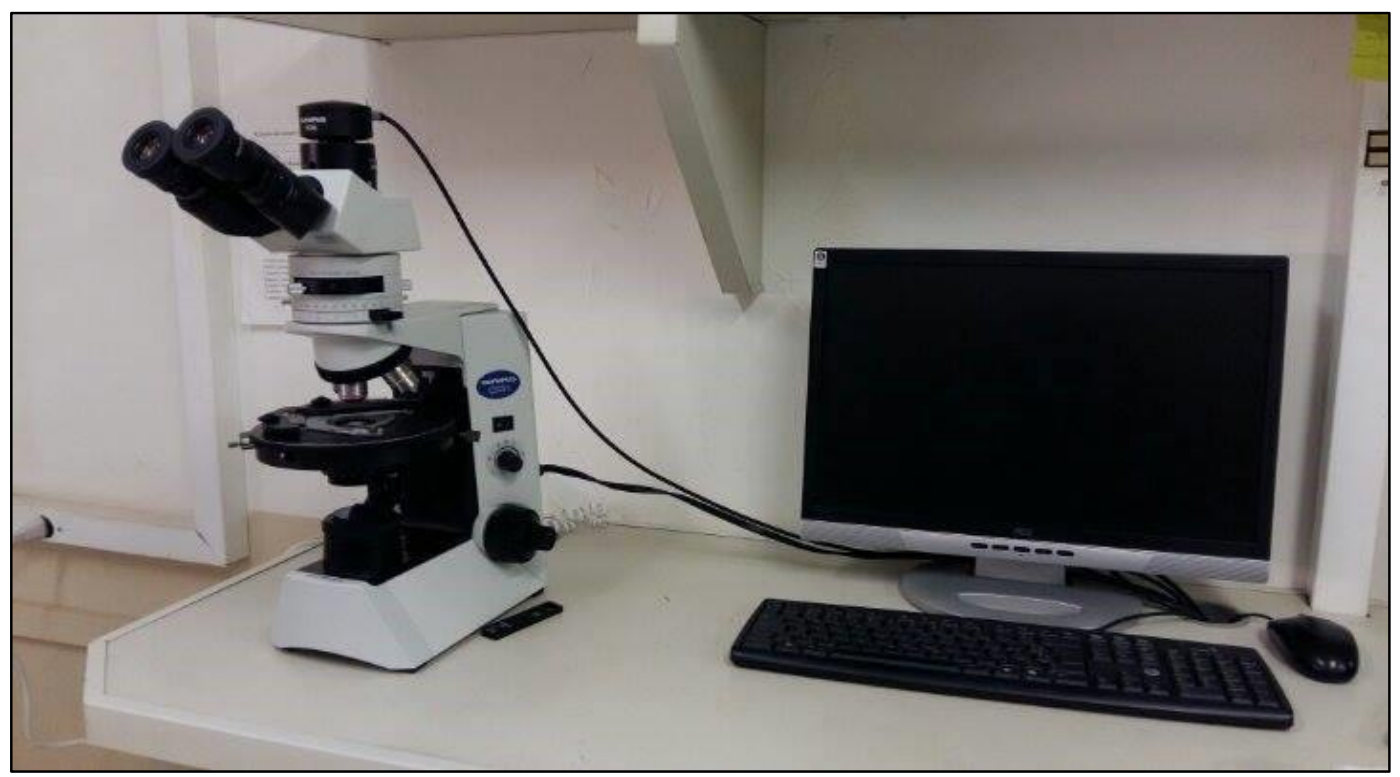

Figura 3.11 - Microscópio óptico utilizado nas análises microscópicas.

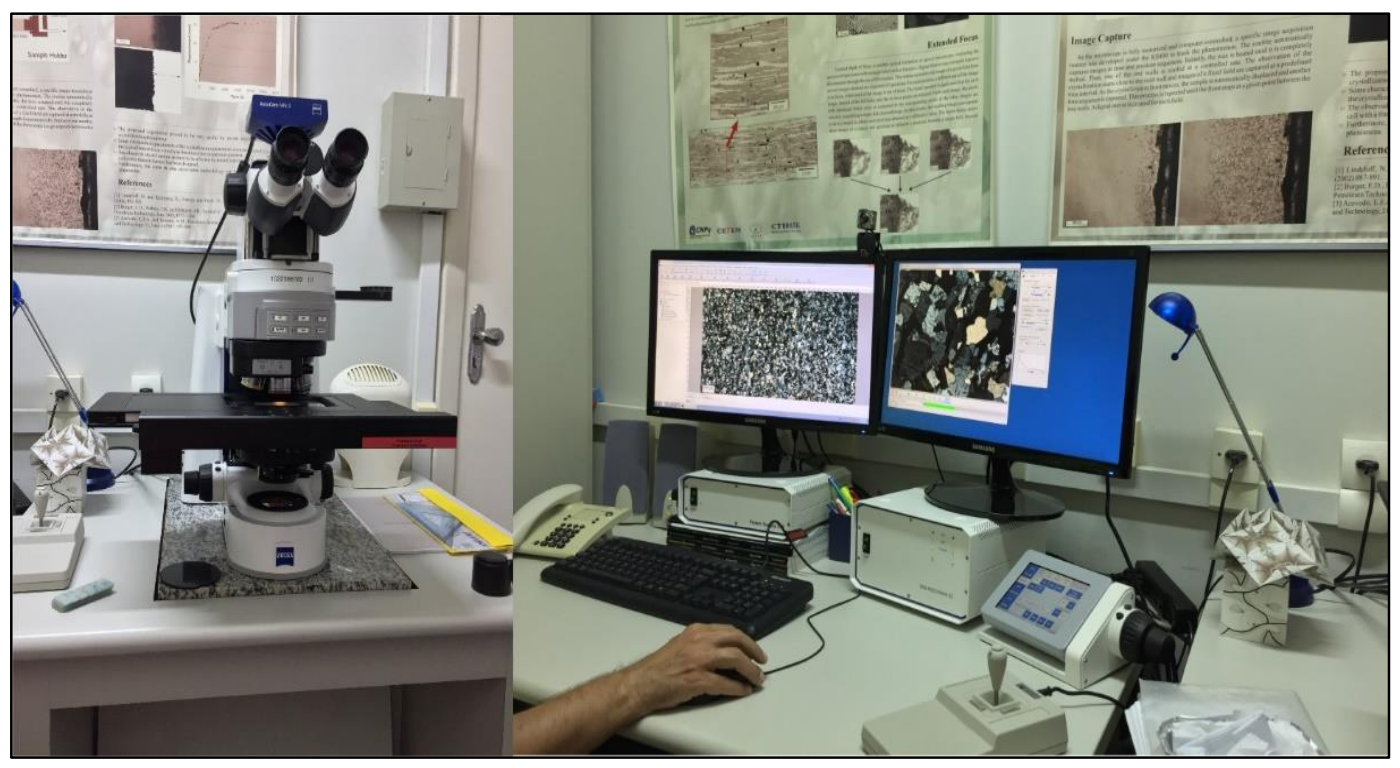

Figura 3.12 - Microscópio óptico utilizado para geração de mosaico de imagens da lâmina.

\subsubsection{Análise de difração de raio $X$}

As análises mineralógicas por difração de raio-X foram realizadas no Laboratório de Caracterização Tecnológica (SCT) do Centro de Pesquisa Mineral (CETEM).

Os ensaios foram executados através do método de difração por pó (powder diffractinon). Primeiramente, as amostras foram destorroadas e moídas no conjunto almofariz e pistilo de ágata, para se evitar contaminação, até ficar com granulometria muito fina. Obteve-se, então, material passante pela peneira com 
abertura de 0,074 mm (ABNT n ${ }^{\circ}$ 200) (figura 3.13a e 3.13b). Foram coletadas 9 (nove) amostras, 3 (três) para cada grau de alteração.

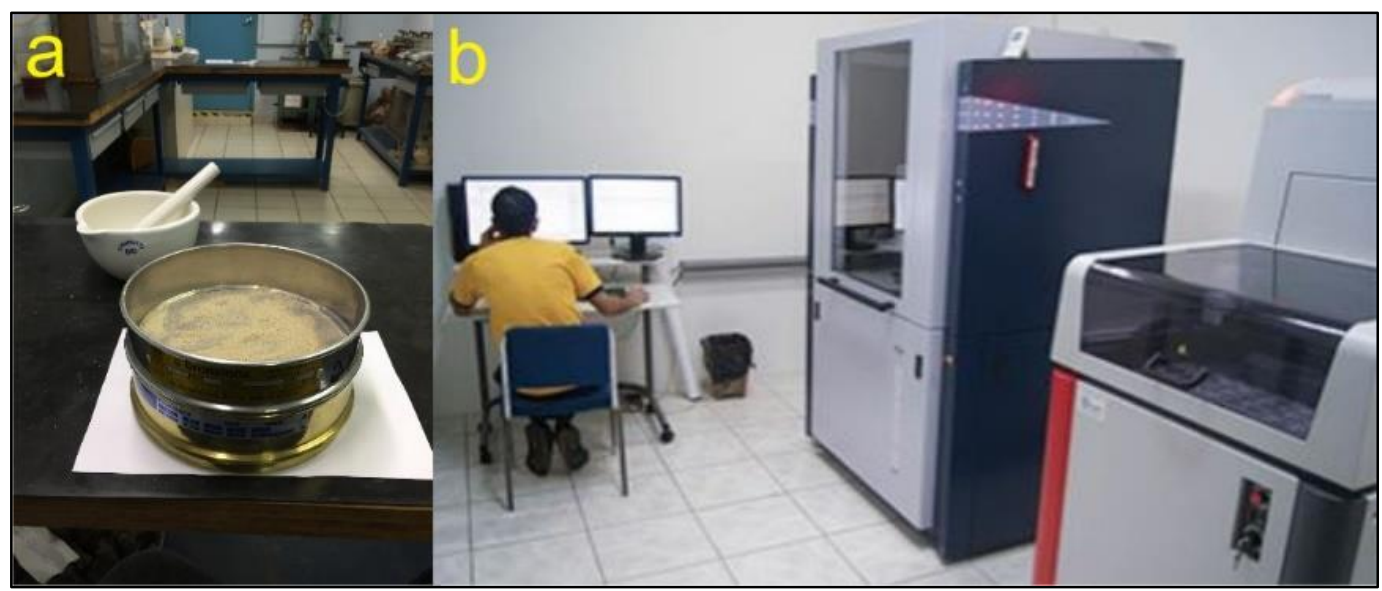

Figura 3.13a - Preparação das amostras / Figura 3.13b - Difratômetro utilizado (fonte: site CETEM).

Os difratogramas de raios-X das amostras foram coletados pelo equipamento Bruker-AXS D8 Advance Eco, nas seguintes condições de operação: radiação $\mathrm{Cu} \mathrm{K \alpha}, \lambda=0,154056 \mathrm{~nm}$, velocidade do goniômetro de $0,02^{\circ} 2 \theta$ por passo com tempo de contagem de 1 segundo por passo coletado de 5 a $80^{\circ} 2 \theta$ e com detector sensível à posição com discriminação de energia LynxEye XE. As interpretações qualitativas de espectro foram efetuadas por comparação com padrões contidos no banco de dados PDF02 (ICOD, 2006) em software Bruker AXS Diffrac Plus.

Os minerais são identificados através de picos produzidos pela difração. Tais picos são registrados em gráficos e correspondem a vários ângulos do goniômetro, a partir dos quais o espaçamento cristalográfico do mineral pode ser calculado pela lei de Bragg.

\subsubsection{Caracterização de índices físicos}

A presença de poros na estrutura das rochas diminui a resistência e aumenta a deformabilidade. Por essa razão, é essencial a quantificação da porosidade nas rochas analisadas. A caracterização dos índices físicos teve como objetivo obter a porosidade e o peso específico seco dos corpos de prova analisados neste trabalho. Todos os corpos de prova foram caracterizados.

Para a realização da caracterização, foi seguida a sugestão da ISRM Suggested Methods for Determining Water Content, Porosity, Density, Absorption 
and Related Properties and Swelling and Slake Durability Index Properties (ISRM, 1979b). A metodologia utilizada nessa etapa pode ser dividida:

1. Os corpos de prova foram imersos em água destilada e saturados dentro de um dessecador conectado a uma bomba de vácuo, cuja pressão não ultrapassou $800 \mathrm{~Pa}$ (6 torr);

2. Foi medida a massa submersa;

3. Foi medida a massa saturada;

4. Os corpos de prova foram colocados na estufa por um período de 24 horas à temperatura de $105^{\circ} \mathrm{C}$;

5. Foi medida a massa seca.

Em relação às especificações dos equipamentos, o dessecador utilizado foi de $250 \mathrm{~mm}$ em plástico. A bomba de vácuo foi o modelo 132 da marca Prismatec, com deslocamento de 2,9 $\mathrm{m}^{2}$ e $48 \mathrm{lpm}$ (figura 3.14a). Foi montado um sistema com duas balanças de precisão, ambas da marca Ohaus (figura 3.14b). A primeira continha um gancho na parte inferior para medir a massa submersa, modelo Adventurer Pro AV8101P, com precisão de uma casa decimal. A segunda foi utilizada para medir as massas saturada e seca, modelo Adventurer ARD110, com precisão de duas casas decimais. Para medir a massa submersa, foi necessário confeccionar uma rede em arames. A estufa utilizada foi da marca Nova Ética.

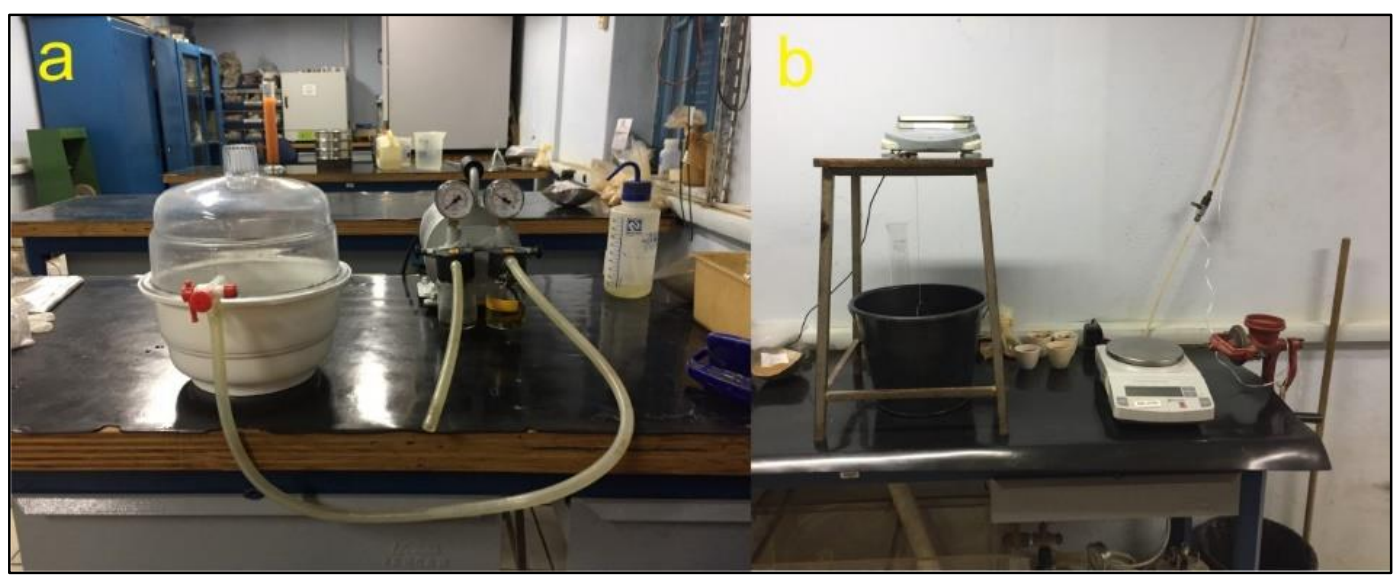

Figura 3.14a - Dessecador e bomba de vácuo utilizado / Figura 3.14b - Sistema montado para medir massa submersa e massa saturada.

Com as três medidas obtidas (massa submersa, massa saturada e massa seca), através das relações contidas na sugestão da ISRM (1979b), foi possível encontrar as propriedades desejáveis:

$$
M_{w}=M_{s a t}-M_{s}
$$




$$
\begin{aligned}
& V=\frac{M_{s a t}-M_{s u b}}{\rho_{w}} \\
& V_{v}=V_{w}=\frac{M_{w}}{\rho_{w}} \\
& V_{s}=V-V_{v} \\
& n=\frac{V_{v}}{V} \times 100 \\
& e=\frac{V_{v}}{V_{s}} \\
& \rho_{d}=\frac{M_{s}}{V} \\
& \gamma_{d}=\rho_{d} g \\
& \rho_{s a t}=\frac{M_{s}+V_{w} \rho_{w}}{V} \\
& \gamma_{s a t}=\rho_{s a t} g \\
& \rho_{s}=\frac{M_{s}}{V_{s}} \\
& \gamma_{s}=\rho_{s} g
\end{aligned}
$$

Onde:

$M_{w}$ - massa de vazios;

$M_{\text {sat }}$ - massa saturada;

$M_{S}$ - massa dos constituintes sólidos;

$M_{\text {sub }}$ - massa submersa;

$V$ - volume total;

$V_{v}=V_{w}-$ volume de vazios;

$\rho_{w}$ - massa específica da água;

$V_{S}$ - volume dos constituintes sólidos;

$n$-porosidade;

$e$ - índice de vazios;

$\rho_{d}$ - massa específica seca;

$\gamma_{d}$ - peso específico seco;

$g$ - aceleração da gravidade;

$\rho_{\text {sat }}$ - massa específica saturada;

$\gamma_{\text {sat }}$ - peso específico saturado;

$\rho_{s}$ - massa específica dos constituintes sólidos;

$\gamma_{s}$ - peso específico dos constituintes sólidos. 
Vale ressaltar que, em função das características da rocha estudada, gnaisses de composição que variam desde quartzo-dioríticas até os tipos granodioríticos, não foi considerada porosidade intrínseca. Outro aspecto que não foi considerado foi a perda de água superficial (poros superficiais), quando medida a massa saturada.

\subsubsection{Ensaio esclerométrico (martelo de Schmidt)}

O ensaio esclerométrico fornece medidas da dureza superficial dos materiais. Tem como principais vantagens: rápida realização, resultado imediato, não ser destrutivo, ser relativamente barato e de manuseio e transporte fáceis. Além de não exigir grande preparação do corpo de prova, pode ainda ser feito in situ.

O equipamento utilizado foi o Martelo de Schmidt do tipo L, da marca Proceq (figura 3.15). Os ensaios foram realizados nas rochas in situ, na pedreira, e nos blocos antes de serem retirados os corpos de prova para os outros ensaios. Os ensaios foram realizados segundo o método sugerido pela ISRM (versão revisada por Aydin, 2009).

O equipamento possui um pistão carregado por uma mola que é liberado após a haste do martelo ser pressionada contra uma superfície. A partir do quociente da velocidade de impacto e da velocidade do rebote, o martelo calcula automaticamente o valor de rebote (Q) (figura 3.16).

Há correlações onde é possível obter o valor da resistência à compressão uniaxial (em virtude do material testado). Aydin (2009) sugere três correlações encontradas na literatura, todas derivadas a partir do estudo de variações de alterações em granitos. No presente trabalho foi utilizada a correlação descrita na equação 3.13 .

$$
U C S=1.45 e^{0,07 Q}
$$

Onde:

$U C S$ - resistência à compressão uniaxial;

$Q$ - valor de rebote do martelo de Schmidt. 


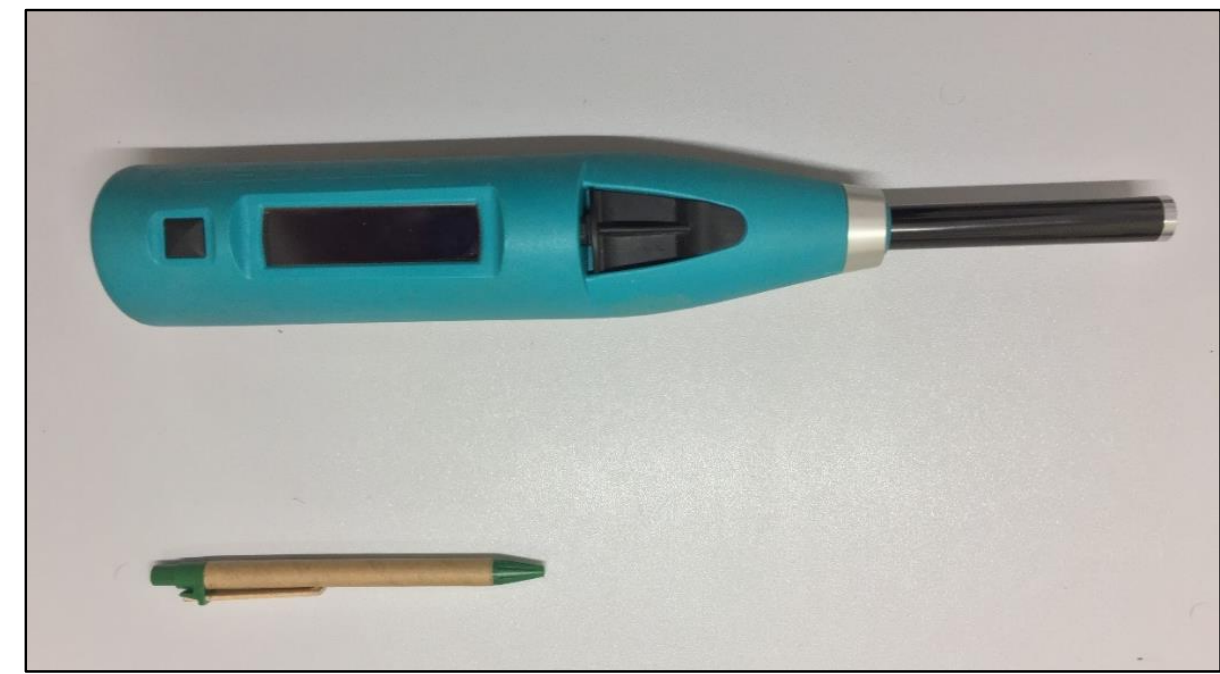

Figura 3.15 - Martelo de Schmidt utilizado, tipo L da marca Proceq.

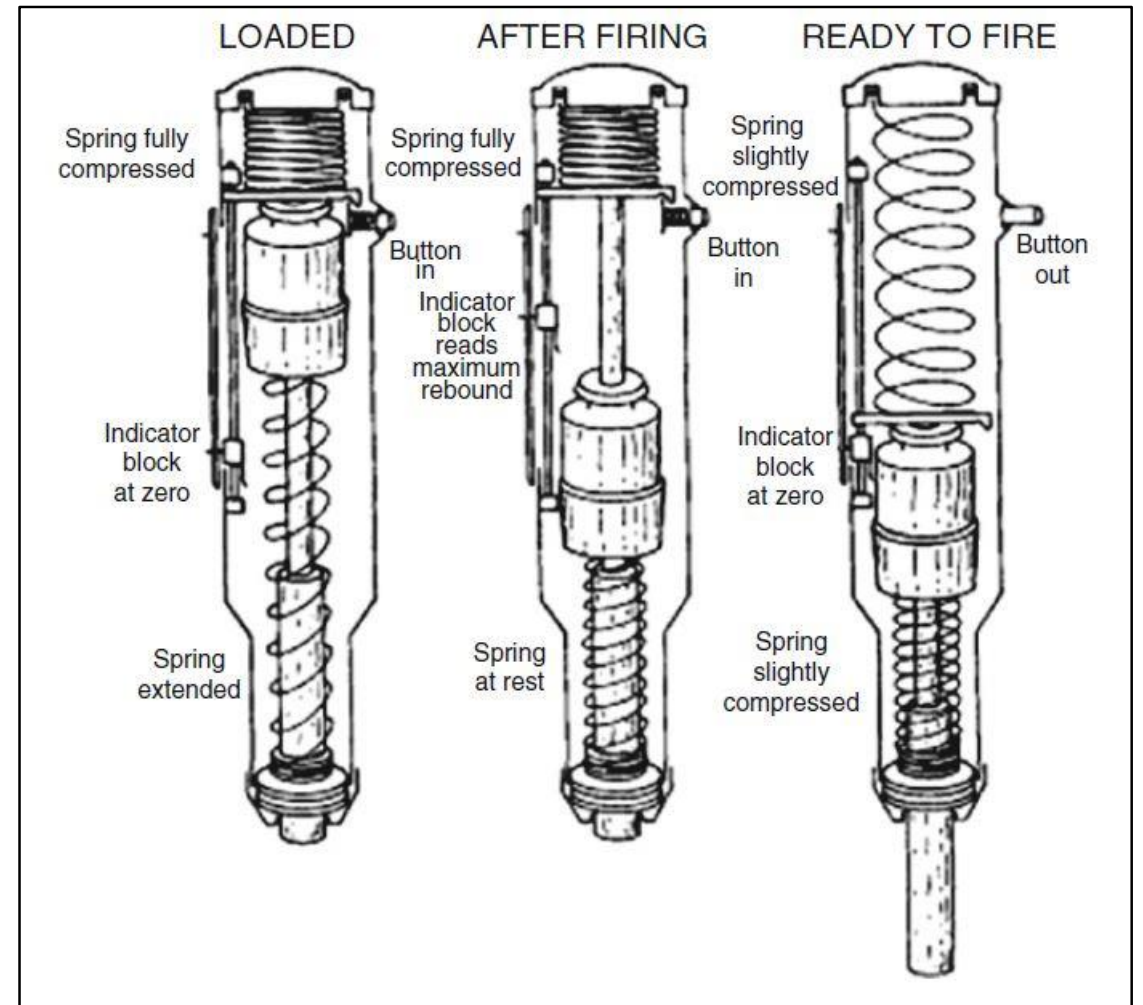

Figura 3.16 - Princípio de funcionamento do esclerômetro (Aydin, 2009).

O equipamento possui um visor digital onde é possível fazer as leituras do rebote $\mathrm{Q}$ e da resistência à compressão uniaxial, através do pré-cadastro da correlação selecionada pelo usuário. 


\subsubsection{Ensaio de resistência à compressão puntiforme}

O ensaio de resistência à compressão puntiforme, também conhecido como Point Load Test, é um método simples, barato e rápido para a obtenção da resistência das rochas (Rusnak \& Mark, 2000). Pelo fato de o equipamento ser portátil, o ensaio pode ser realizado no campo ou no laboratório e requer uma mínima preparação das amostras.

Os ensaios foram realizados no Laboratório de Estruturas e Materiais da PUC-Rio e seguiram a metodologia sugerida pela ISRM (ISRM, 1985). O equipamento utilizado foi o PLT, modelo PLT-i, da marca Martins Campelo (figura 3.17). Ele possui duas prensas cônicas, que são ajustadas de acordo com o tamanho do corpo de prova. Nelas são aplicadas as cargas. $\mathrm{O}$ aparelho possui um visor digital, que mostra o valor da força máxima aplicada (kgf) para cada teste, e também possui entrada para cartão de memória onde são gravados os resultados.

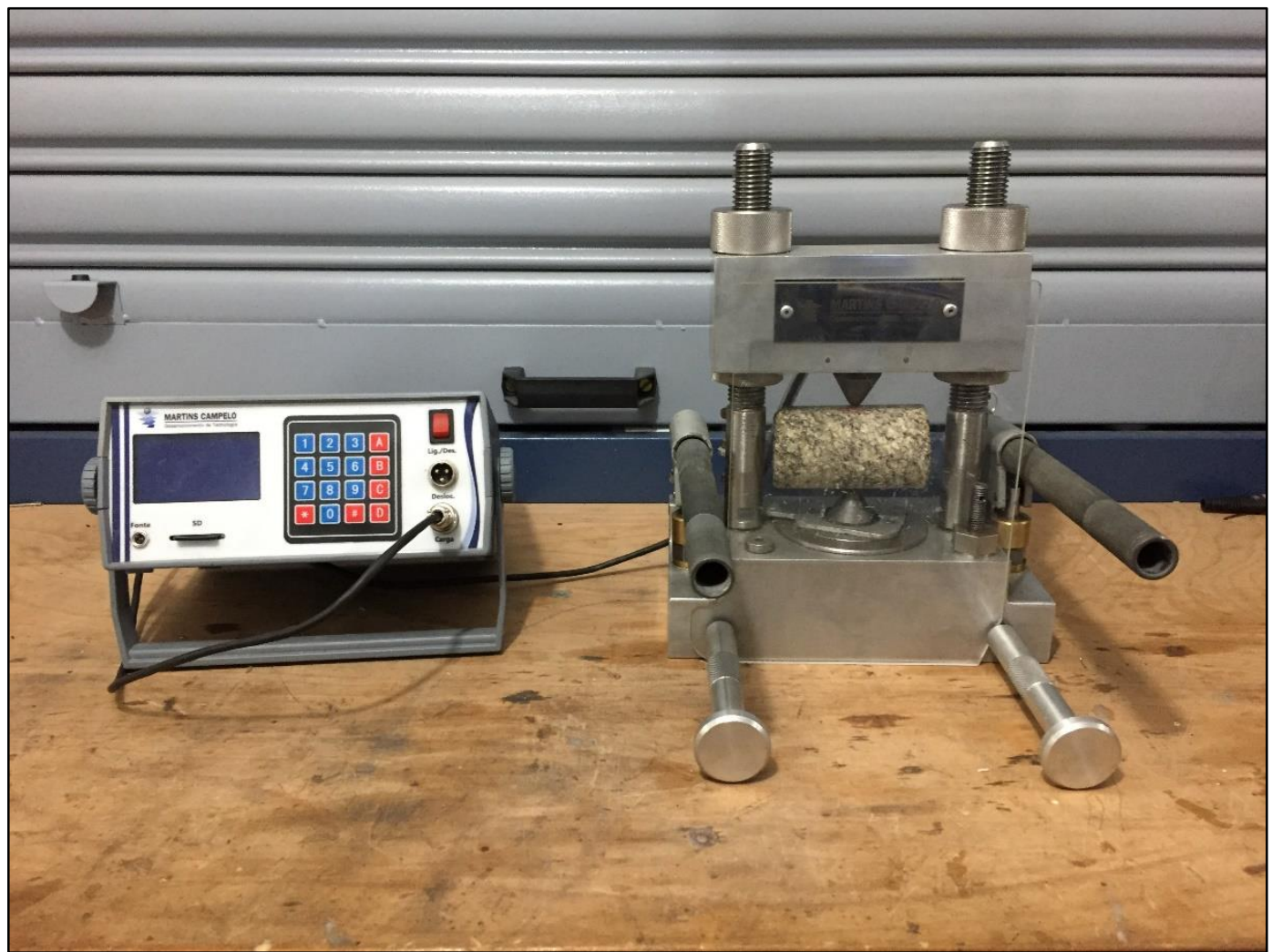

Figura 3.17 - Equipamento utilizado para o Point Load Test.

Foram realizados testes axiais e diametrais. Quando possível, foi realizado primeiramente o teste diametral, após o rompimento os dois pedaços restantes foram preparados e ensaiados axialmente (figura 3.18). 


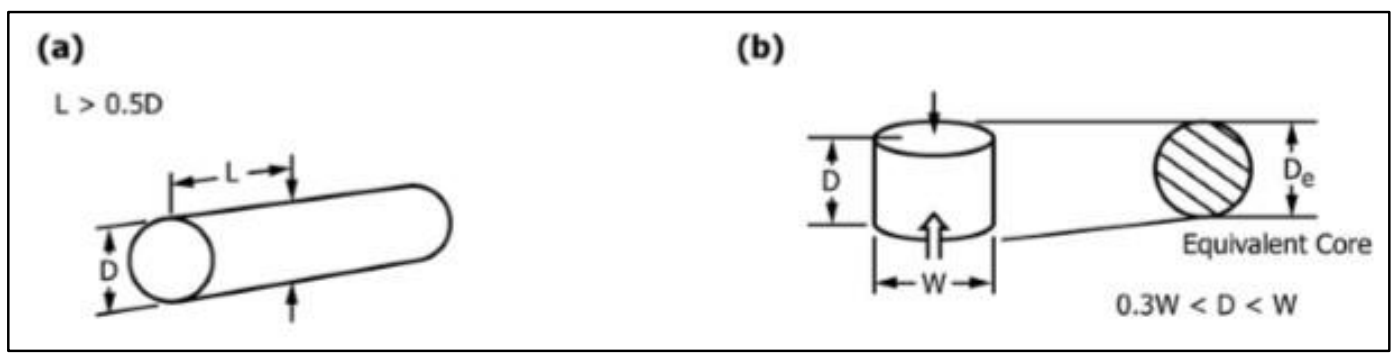

Figura 3.18 - Configuração da geometria requerida para o Teste Diametral (a) e Teste Axial (b) (ISRM, 1985).

Onde o diâmetro equivalente do corpo de prova $\left(\mathrm{D}_{\mathrm{e}}\right)$ é obtido de acordo com as equações abaixo:

$$
\begin{aligned}
& D_{e}=D^{2} \text { para teste diametral } \\
& D_{e}=\frac{4(W D)}{\pi} \text { para teste axial }
\end{aligned}
$$

O índice de resistência puntiforme $\left(I_{\mathrm{s}}\right)$ é então calculado através da equação abaixo:

$$
I_{s}=\frac{P}{D_{e}^{2}}(M P a)
$$

\section{Onde:}

$\mathrm{P}=$ carga aplicada na ruptura $(\mathrm{N})$;

$\mathrm{D}_{\mathrm{e}}=$ diâmetro equivalente $(\mathrm{mm})$.

É possível correlacionar o valor de Is com a resistência à compressão uniaxial $\left(\sigma_{c}\right)$ através de um fator $\mathrm{K}$, que depende do diâmetro da amostra. $\mathrm{O}$ valor de $\mathrm{K}$ para diâmetro de $54 \mathrm{~mm}$ é 24, gerando a relação apresentada abaixo:

$$
\sigma_{c}=24 I_{s}(M P a)
$$

Broch (1983) faz uma importante observação em relação à força aplicada nos corpos de prova com direção de foliação diferente de paralela ou perpendicular. O teste diametral deve ser realizado de modo que a força seja aplicada ao longo do menor diâmetro do plano elíptico de foliação, como mostra a figura 3.19. O autor também comenta que o ângulo $\beta$ entre o eixo do corpo de prova e a foliação só influenciam o resultado do teste para valores entre $30^{\circ}$ e $60^{\circ}$, mostrado na figura 3.20 (Aagaard, 1976, apud Broch, 1983). 


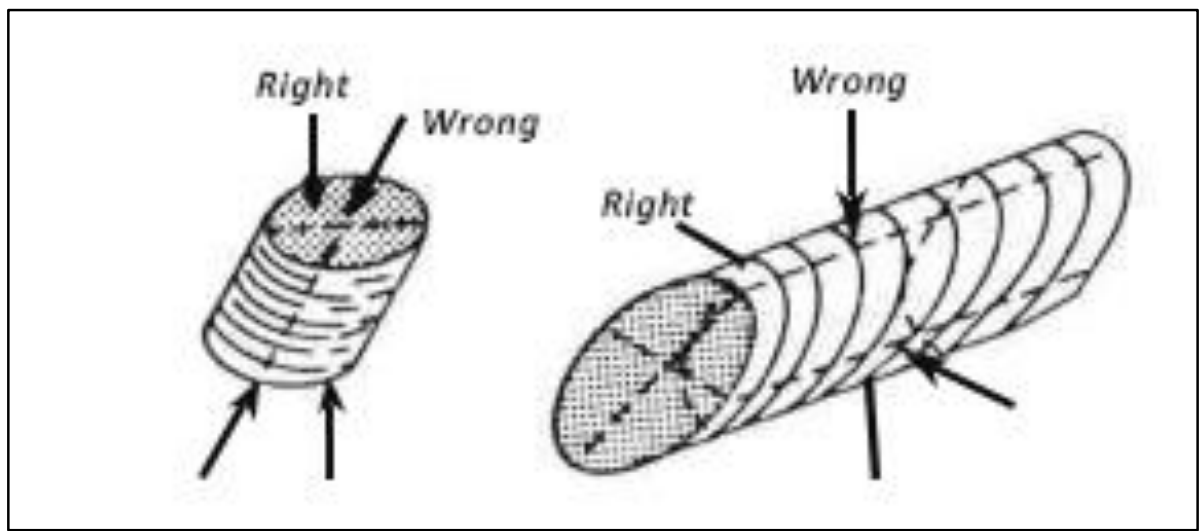

Figura 3.19 - Direções corretas e incorretas da aplicação da carga para obtenção de valores máximos e mínimos de Is (Broch, 1983).

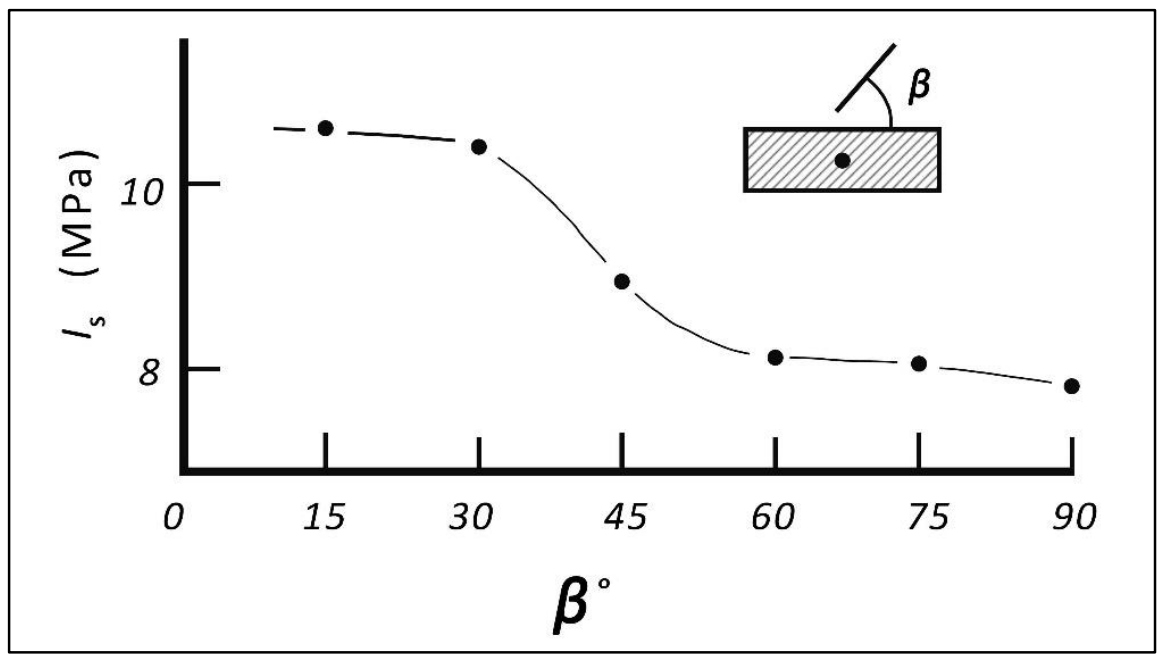

Figura 3.20 - Variação do Is em função do ângulo $\beta$, entre o eixo do corpo de prova e a foliação da rocha, para forças aplicadas paralelamente ao plano de foliação (Aagaard, 1976 apud Broch, 1983).

\subsubsection{Ensaio de resistência à compressão uniaxial}

O ensaio de resistência à compressão simples ou uniaxial (UCS) é um dos ensaios mais comum em mecânica das rochas para determinação da resistência e da deformabilidade das rochas. Por sua grande utilização, é considerado um parâmetro de caracterização do material. Azevedo \& Marques (2002) mencionam que muitas pessoas o consideram um ensaio de simples execução.

Os ensaios foram realizados em uma máquina de ensaios universais da marca MTS, modelo 810, com garras hidráulicas e capacidade de carga de 500 $\mathrm{kN}$, pertencente ao laboratório de Estruturas e Materiais da PUC-Rio (figura $3.21)$. 
Foram utilizados dois extensômetros em cada corpo de prova para medir a deformação axial do material. O extensômetro utilizado foi o modelo PA-06201BA-120L (F.S.: 2,16) da marca Excel Sensores Ind. Com. Exp. LTDA.

A prensa é controlada pelo software MTS TestSuite ${ }^{\mathrm{TM}}$ Multipurpose Elite (MPE) da marca MTS. A aquisição de dados da instrumentação foi realizada pelo software CATMAN Easy AP, da empresa HBM. Força e deslocamento do equipamento foram controlados através do módulo 1, pelo sistema MX-1615B, enquanto os extensômetros foram controlados através do módulo 2, sistema MX440B.

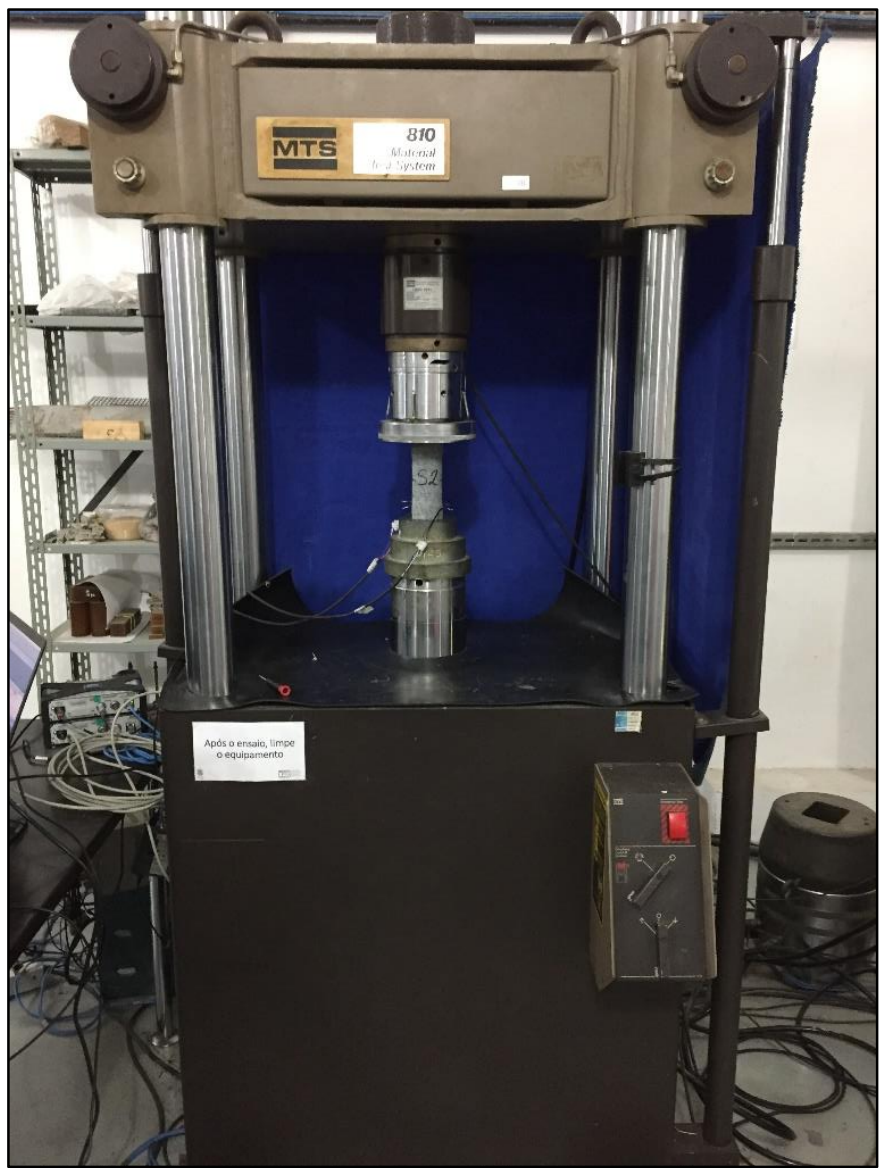

Figura 3.21 - Ensaio de resistência à compressão uniaxial realizado na máquina de ensaios universais da marca MTS, modelo 810.

Os ensaios foram realizados seguindo as sugestões da ISRM (ISRM, 1979a). Os corpos de prova seguiram a geometria padrão, com 54 mm diâmetro e $135 \mathrm{~mm}$ de comprimento, mantendo a relação de 2,5 a 3,0 (ISRM, 1979a).

O controle do ensaio foi feito por deslocamento do extensômetro, de modo a se obter um melhor controle da ruptura dos corpos de prova. A taxa utilizada foi 
de $4,5 \times 10^{-4} \mathrm{~mm} / \mathrm{s}$. A resistência à compressão simples da rocha foi obtida através da expressão abaixo:

$$
\sigma_{c}=\frac{P}{A_{0}}
$$

Onde:

$\sigma_{c}$ - resistência à compressão simples;

$P$ - maior força aplicada à amostra durante o ensaio;

$A_{0}$ - área inicial da seção transversal do corpo de prova.

Em função da quantidade de amostras disponíveis, os corpos de prova foram extraídos com controle da foliação, de maneira que a foliação ficou com inclinação maior que $45^{\circ}$ em relação ao plano de aplicação da carga, de modo a se obter a menor resistência à compressão (Goodman, 1989) (figura 3.22).

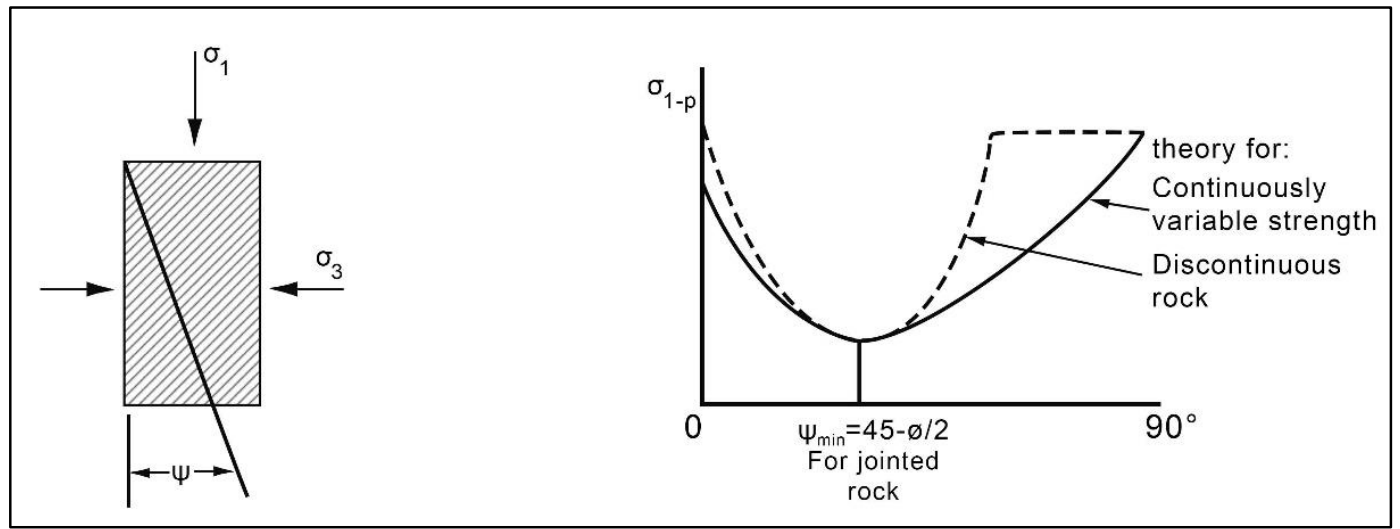

Figura 3.22 - Resistência à compressão de rochas anisotrópicas (Goodman, 1989).

\subsubsection{Ensaio indireto de resistência à tração (ens. Brasileiro)}

As rochas, em geral, apresentam boa resistência à compressão mas não à tração, tornando esse um parâmetro mecânico muito importante, pois é a causa de muitos problemas encontrados nos projetos de engenharia, como fraturamento hidráulico, quedas de lascas e/ou blocos, problemas em escavações subterrâneas, entre outros.

Existem ensaios diretos e indiretos para a determinação da resistência à tração, porém os ensaios diretos apresentam grandes dificuldades experimentais. Esse fato levou à criação de diversos métodos indiretos de medidas. O mais conhecido deles é o ensaio Brasileiro. 
O ensaio Brasileiro consiste na aplicação de uma força de compressão diametral. Dessa forma, o corpo de prova rompe por tração. É um ensaio de baixo custo, comparado aos ensaios diretos, rápida execução, fácil adequação de máquinas para sua realização e facilidade na preparação das amostras.

Os ensaios foram realizados seguindo as sugestões da ISRM (ISRM, 1978). A geometria do corpo de prova possui forma de disco e possui relação diâmetroespessura de 2:1. No presente trabalho, utilizou-se o diâmetro mínimo sugerido pela ISRM, $54 \mathrm{~mm}$ e espessura de $27 \mathrm{~mm}$.

Foi utilizada a máquina de ensaios universais da marca MTS, modelo 810 com garras hidráulicas e capacidade de carga de $500 \mathrm{kN}$, pertencente ao laboratório de Estruturas e Materiais da PUC-Rio. Nessa mesma máquina foram realizados os ensaios de compressão uniaxial. Foi utilizado um suporte de aço com dois mordentes curvos, superior e inferior, ligados por dois pinos guias (ISRM, 1978). A amostra é colocada no suporte, e o conjunto colocado na prensa (figura 3.23).

A prensa é controlada pelo software MTS TestSuite ${ }^{\mathrm{TM}}$ Multipurpose Elite (MPE) da marca MTS. Os ensaios não foram instrumentados, apenas foram coletados os dados do atuador: força axial aplicada, tempo e deslocamento axial.

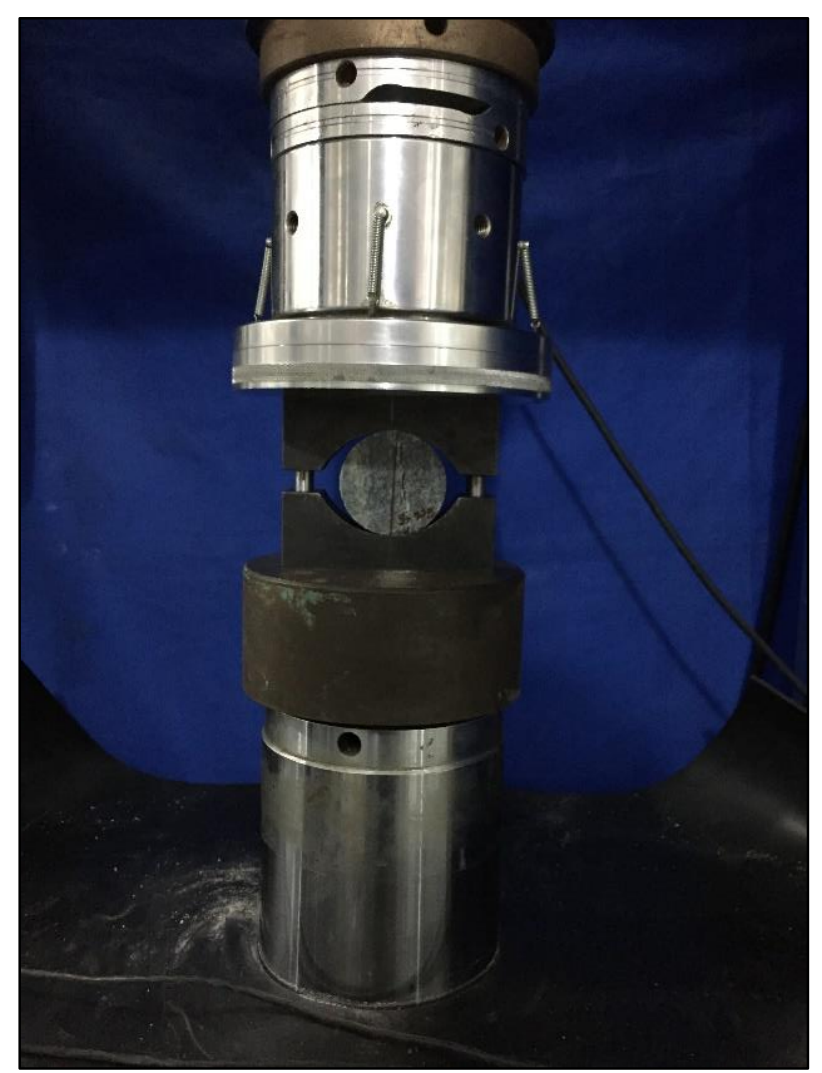

Figura 3.23 - Ensaio para determinação da resistência à tração indireto (Ensaio Brasileiro). 
A taxa de carregamento utilizada foi a recomendada pela ISRM (1978), 200 N/s. A resistência à tração é calculada de acordo com a teoria da elasticidade através da expressão abaixo:

$$
\sigma_{t}=\frac{2 P}{\pi d t}=0,636 \frac{P}{d t}
$$

\section{Onde:}

$P$ - carga de falha;

$d$-diâmetro do corpo de prova;

$t$ - espessura do corpo de prova.

A ruptura ocorre ao longo do diâmetro do disco no plano paralelo ao carregamento. A carga para o cálculo é referente à primeira fissura, pois rupturas secundárias são produzidas quando o carregamento é mantido. Fissuras secundárias também podem ocorrer por imperfeições do corpo de prova ou na execução do ensaio. É comum, após a primeira fratura, a amostra apresentar uma pequena diminuição na sua resistência, para, em seguida, ocorrer aumento da carga, inclusive superior à carga correspondente à fratura primária.

Os valores obtidos nos ensaios brasileiros apresentam uma boa aproximação da resistência à tração uniaxial e, em geral, são um pouco superiores (Nunes, 1989 apud Almeida, 1999). O principal motivo, segundo o autor, é por conta de a superfície de ruptura ser imposta e nem sempre ser a de menor resistência. Essa imposição levanta dificuldades em relação à interpretação de rochas anisotrópicas.

De maneira a dirimir tal fato, os corpos de prova foram extraídos com controle de foliação, paralelos à foliação. Dessa maneira os ensaios puderam ser realizados com a foliação paralela, ortogonal e inclinada.

\subsubsection{Ensaio de tenacidade à fratura CCNDB}

Para determinação da tenacidade à fratura no modo I de rochas intactas, a ISRM recomenda a utilização do CCNDB (Determining Mode I Fracture Toughness: Suggested Method Using Cracked Chevron Noched Brazilian Disc (CCNDB) Specimens - ISRM, 1995). Trata-se de realizar o ensaio com corpo de prova no formato de disco brasileiro com entalhe em V (ou “chevron”). 
Os corpos de prova, após os preparos descritos no item 3.1.3, foram encaminhados para o Laboratório de Mecânica da PUC-Rio, para a confecção do entalhe chevron, o qual foi feito com serra diamantada de $52 \mathrm{~mm}$ de diâmetro. A serra penetra $16,95 \mathrm{~mm}$ em cada face do corpo de prova. Para o procedimento descrito, foi utilizada Fresadora com Variador Digital da marca Diplomat (figura $3.24)$.

Os ensaios foram realizados no Laboratório de Estruturas e Materiais da PUC-Rio. Foi utilizada a máquina de ensaios universais da marca MTS, modelo 810 com garras hidráulicas e capacidade de carga de $500 \mathrm{kN}$.

Como sugerido pela ISRM (1995), foram instalados LVDTs para controlar o deslocamento durante o ensaio. Como não foi possível colocar garras magnéticas no equipamento, foi confeccionado um conjunto de duas hastes com suportes em acrílico para colocar os LVDTs (figura 3.25).

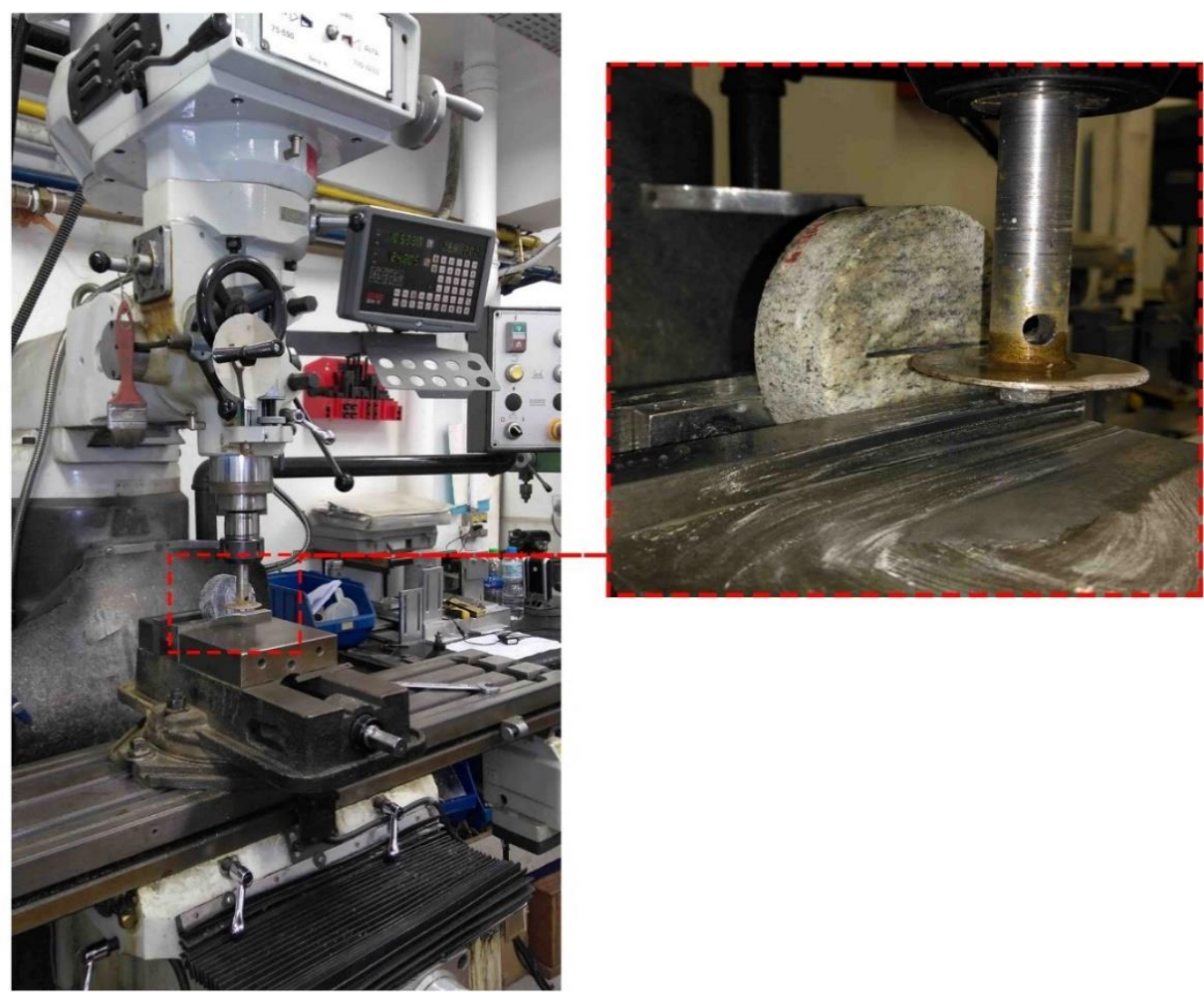

Figura 3.24 - Procedimento realizado para a confecção do entalhe chevron, para ensaios CCNDB. 


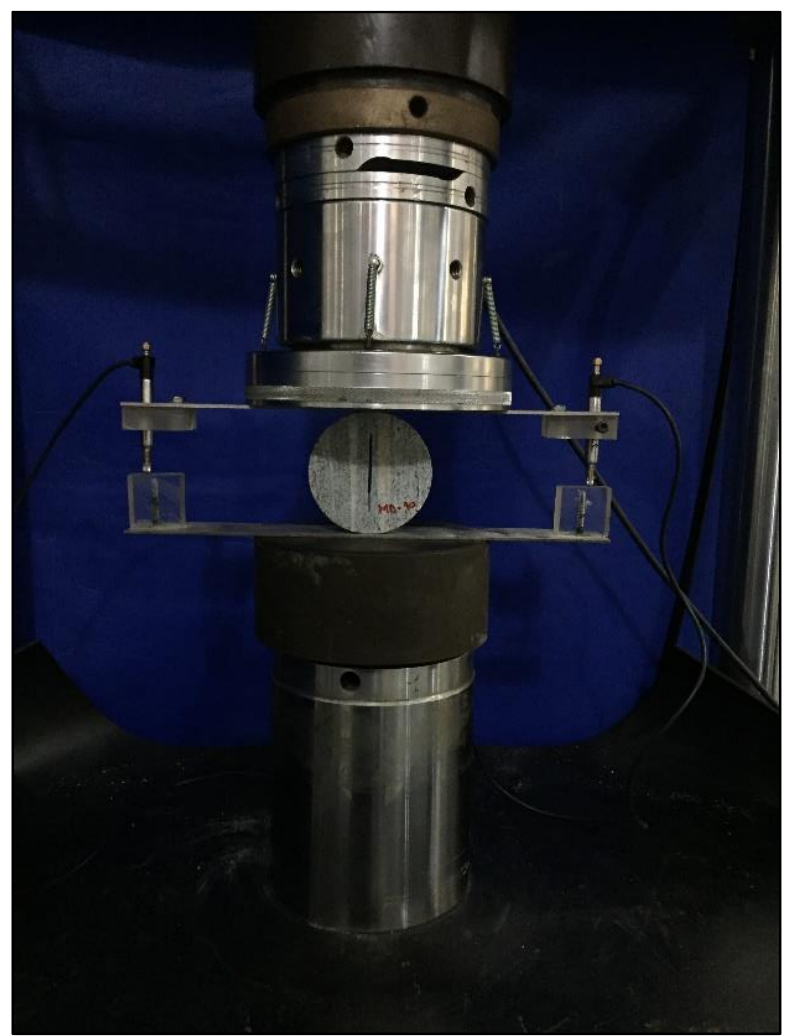

Figura 3.25 - Ensaio para determinação da tenacidade à fratura do tipo CCNDB.

Os dois LVDTs utilizados são da marca HBM, modelo TYP WI 5 mm. A prensa é controlada pelo software MTS TestSuite ${ }^{\mathrm{TM}}$ Multipurpose Elite (MPE) da marca MTS. A aquisição de dados da instrumentação foi realizada pelo software CATMAN Easy AP, da empresa HBM. Força e deslocamento do equipamento foram controlados através do módulo 1 pelo sistema MX-1615B, enquanto os LVDTs foram controlados através do módulo 2, sistema MX-440B.

Apesar de o CCNDB ser um ensaio onde é avaliada a tenacidade à fratura para o nível I, em que apenas o registro da carga máxima aplicada é requerido, foram realizados dois testes com extensômetros do tipo "clip gauge", onde houve o controle da abertura da boca da fissura. O objetivo deste ensaio foi controlar melhor a propagação da fissura, realizada de maneira rápida nos outros ensaios, com menos de 20 segundos (ISRM, 1995).

Foram ensaiados dois corpos de prova de rocha sã utilizando o clip gauge, um com entalhe paralelo à foliação e outro ortogonal à foliação. $\mathrm{O}$ clip gauge utilizado foi da marca MTS, modelo 632.028-20.

$\mathrm{Na}$ tabela 2.1, no capítulo anterior, foi fornecida a geometria padrão sugerida pela ISRM, porém existem outras possibilidades diferentes da apresentada. Todas as dimensões da geometria do corpo de prova devem ser 
convertidas em parâmetros adimensionais com relação ao raio do corpo de prova, conforme apresentados abaixo:

$$
\begin{aligned}
& \alpha_{0}=\frac{a_{0}}{R} \\
& \alpha_{1}=\frac{a_{1}}{R} \\
& \alpha_{B}=\frac{B}{R} \\
& \alpha_{S}=\frac{R_{S}}{R}
\end{aligned}
$$

\section{Onde:}

$B$ - espessura do corpo de prova;

$R_{s}$ - raio da serra usada para fazer o entalhe no corpo de prova.

$\alpha_{0}, \alpha_{1}$ e $\alpha_{B}$ são as três dimensões básicas para os parâmetros geométricos do CCNDB. Outras dimensões podem ser calculadas através das relações abaixo:

$$
\begin{aligned}
& \alpha_{s}=\frac{R_{s}}{R}=\sqrt{\alpha_{0}^{2}+\left(\alpha_{1}^{2}-\alpha_{0}^{2}+\frac{\alpha_{B}^{2}}{4}\right) \div \alpha_{B}^{2}} \\
& h_{c}=\left(\alpha_{s}-\sqrt{\alpha_{s}^{2}-\alpha_{1}^{2}}\right) R=\left(\alpha_{s}-\sqrt{\alpha_{s}^{2}-\alpha_{0}^{2}}\right) R+\frac{B}{2} \\
& \alpha_{0}=\sqrt{\alpha_{s}^{2}-\left(\sqrt{\alpha_{s}^{2}-\alpha_{1}^{2}}+\frac{\alpha_{B}}{2}\right)^{2}} \\
& \alpha_{1}=\sqrt{\alpha_{s}^{2}-\left(\sqrt{\alpha_{s}^{2}-\alpha_{0}^{2}}-\frac{\alpha_{B}}{2}\right)^{2}} \\
& \alpha_{B}=2\left(\sqrt{\alpha_{s}^{2}-\alpha_{0}^{2}}-\sqrt{\alpha_{s}^{2}-\alpha_{1}^{2}}\right)
\end{aligned}
$$

Para os testes serem válidos, os corpos de prova precisam satisfazer às seguintes condições:

$$
\begin{aligned}
& \alpha_{1} \geq 0,4 \\
& \alpha_{1} \geq \frac{\alpha_{B}}{2} \\
& \alpha_{B} \leq 1,04 \\
& \alpha_{1} \leq 0,8 \\
& \alpha_{B} \geq 1,1729 \cdot \alpha_{1}^{1,6666} \\
& \alpha_{B} \geq 0,44
\end{aligned}
$$


Como mencionado no item 2.4 do capítulo 2 , a tenacidade à fratura $\left(\mathrm{K}_{\mathrm{IC}}\right)$ é obtida através da equação 2.19 .

$$
K_{I C}=\frac{P_{\max }}{B \sqrt{D}} Y_{\min }^{*}
$$

Onde:

$P_{\text {max }}$ - força máxima aplicada;

$B$ - espessura do corpo de prova;

$D$ - diâmetro do corpo de prova;

$Y_{\min }^{*}$ - valor crítico (mínimo) do fator de intensidade de tensão adimensional para o corpo de prova.

$Y_{\min }^{*}$ é determinado em função das dimensões geométricas do corpo de prova $\left(\alpha_{0}, \alpha_{1}\right.$ e $\left.\alpha_{B}\right)$, conforme a expressão abaixo:

$$
Y_{\min }^{*}=u e^{v \alpha_{1}}
$$

Onde:

$u$ e $v$ - são constantes tabeladas na sugestão da ISRM (1995) e determinados em função de $\alpha_{0}$ e $\alpha_{B}$. 


\section{4 Apresentação e discussão dos resultados}

Neste capítulo são apresentados os resultados dos ensaios mencionados no capítulo anterior em função do grau de alteração das amostras coletadas.

\section{1}

\section{Análise petrográfica}

O principal objetivo da análise petrográfica neste trabalho foi analisar as características estruturais e mineralógicas das rochas, visando confirmar o grau de alteração, previamente estabelecido na descrição táctil visual macroscópica.

A petrografia das rochas gnáissicas não revela grandes diversificações mineralógicas e texturais. Ocorre apenas variação na composição modal, variando de quartzo-diorítica a granodiorítica (por conta da variação da relação plagioclásio/K-feldspato), e, por vezes, variação na granulometria de fina a média.

\section{Rocha sã}

É um gnaisse de composição granodiorítica, com bandamento gnáissico bem marcado, denotado pelo alinhamento de bandas félsicas (feldspato e quartzo) e máficas (biotita), com texturas lepidoblástica e granonematoblástica. É uma rocha equigranular com granulometria fina, apresenta índice de cor mesocrático. A composição mineralógica é dada por quartzo, plagioclásio, microclima, biotita e minerais opacos.

O quartzo é incolor, tem cor de interferência baixa, cinza, possui hábito granular, pseudo-hexagonal, tendendo ao arredondado. Há duas gerações de quartzo: uma com grãos mais euédricos e outra, mais tardia, com grãos mais anédricos e ligeiramente superiores. O plagioclásio também é incolor, possui baixa cor de interferência (cinza), tem hábito prismático com grãos subédricos e apresenta-se geminado pela Lei da Albita. Alguns grãos maiores apresentam sinais de saussuritização, geminação Carlsbad e inclusões de pequenos grãos de 
quartzo. Os grãos de microclima possuem as mesmas características do plagioclásio. A diferença está na geminação, neste caso Tartan. A biotita tem cor natural e de interferência marrom, com grãos euédricos de hábito lamelar.

As figuras 4.1 e 4.2 apresentam os mosaicos das lâminas de rocha sã com e sem luz polarizadas, respectivamente.

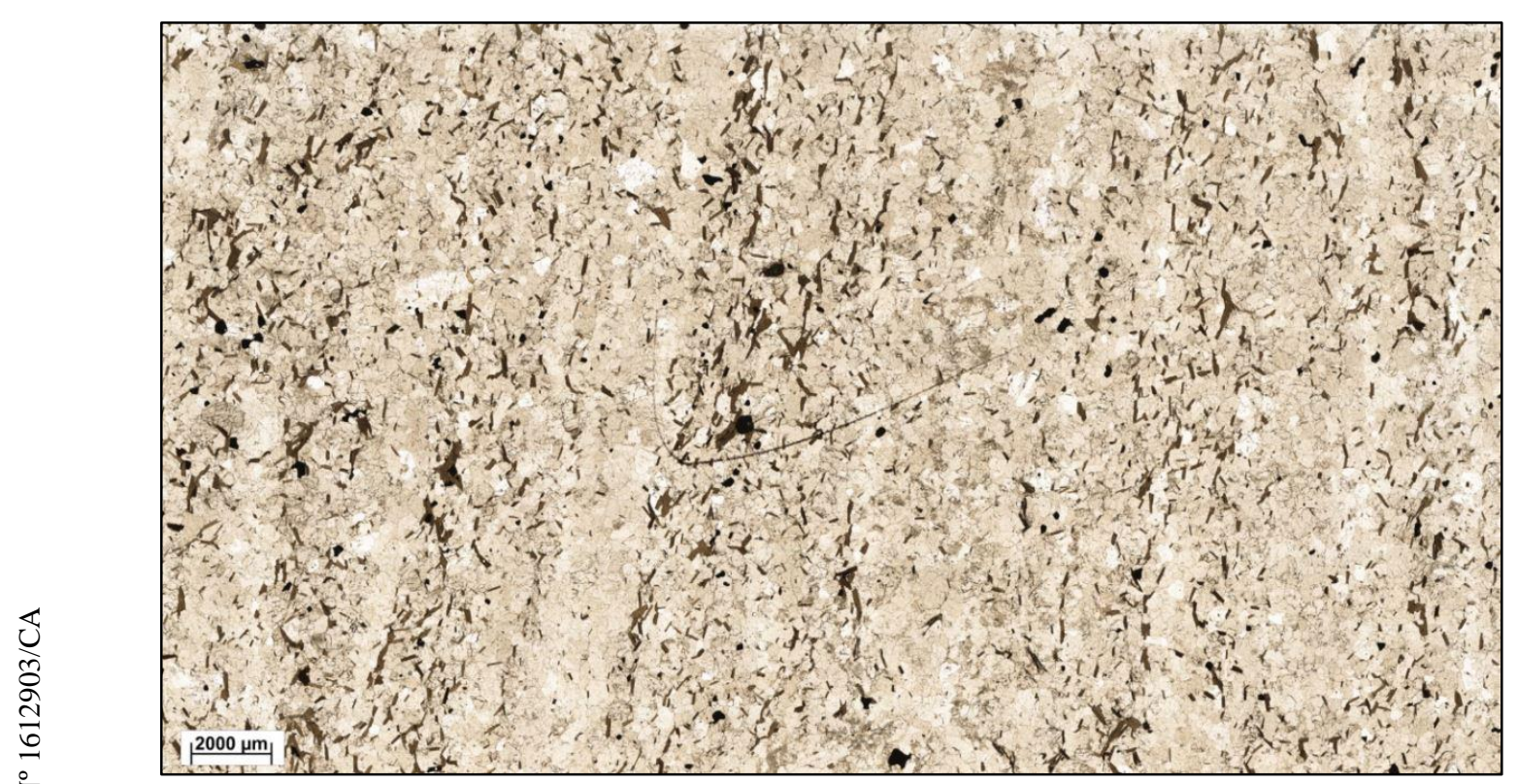

Figura 4.1 - Mosaico da lâmina petrográfica da rocha sã (luz transmitida polarizada).

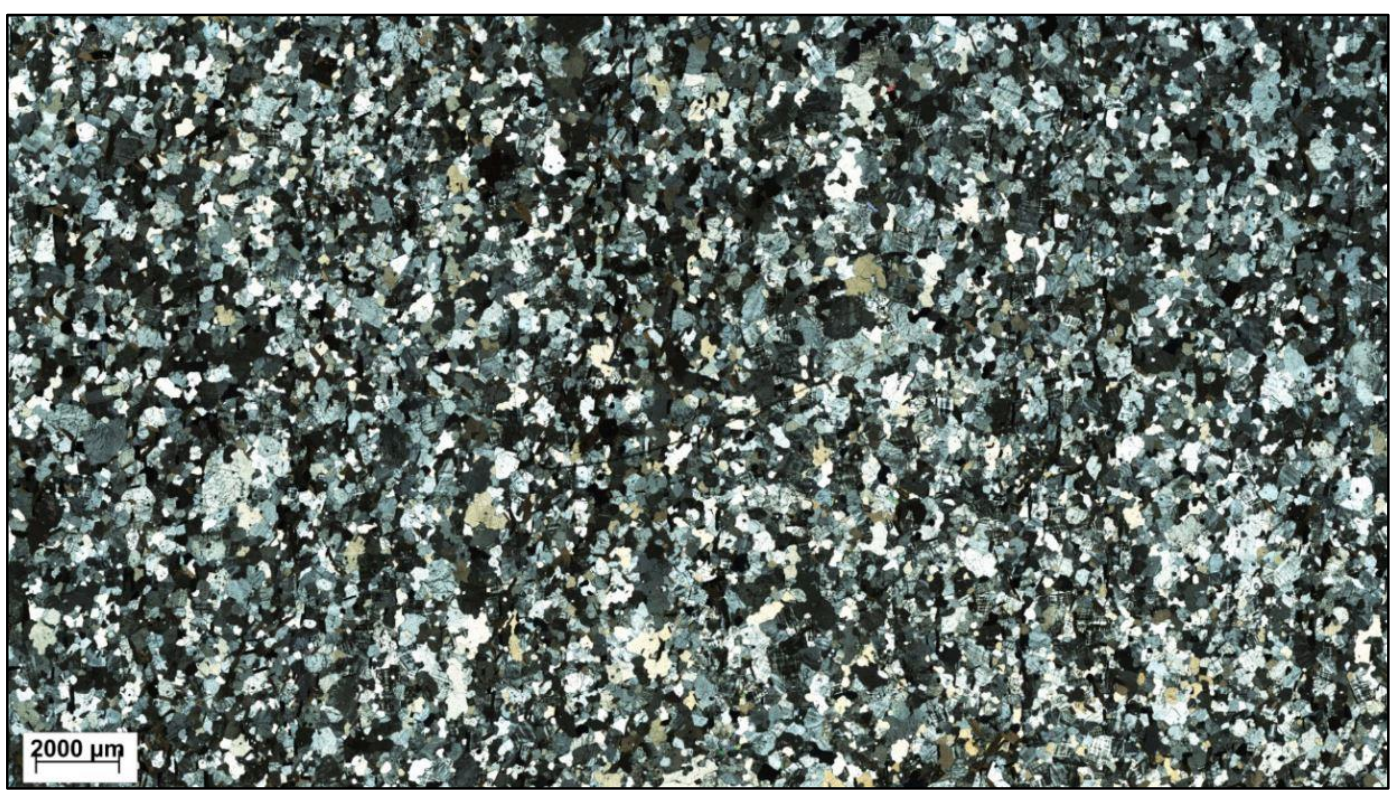

Figura 4.2 - Mosaico da lâmina petrográfica da rocha sã (luz transmitida polarizada com nicóis cruzados). 


\section{Rocha medianamente alterada}

É um gnaisse quartzo-diorítico, sem bandamento bem marcado. A rocha é inequigranular com granulometria variando de fina a média e índice de cor mesocrático. A grande maioria dos grãos médios se apresentam com muitas fraturas, isso aliado ao fato de diversos grãos apresentarem sinais de recristalização, pode ser indicativo da identificação do grau de alteração da rocha.

A composição mineralógica é dada por plagioclásio, quartzo, biotita, hornblenda, microclima, titanita e minerais opacos.

O plagioclásio, quartzo, biotita e microclina apresentam as mesmas características básicas descritas na rocha sã. Como mencionado, os grãos médios de plagioclásio e quartzo estão fraturados. Grãos saussuritizados de plagioclásios são mais comuns. A rocha apresenta alguns grumos máficos, formados por biotita, hornblenda, titanita e minerais opacos. A hornblenda tem cor marrom um pouco esverdeada. Sua cor de interferência quase não altera, possui hábito granular e grãos subédricos. A titanita é um mineral acessório, com cor natural e de interferência castanho (próximo ao marrom), hábito granular e grãos subédricos.

As figuras 4.3 e 4.4 apresentam os mosaicos das lâminas de rocha medianamente alterada com e sem luz polarizadas, respectivamente.

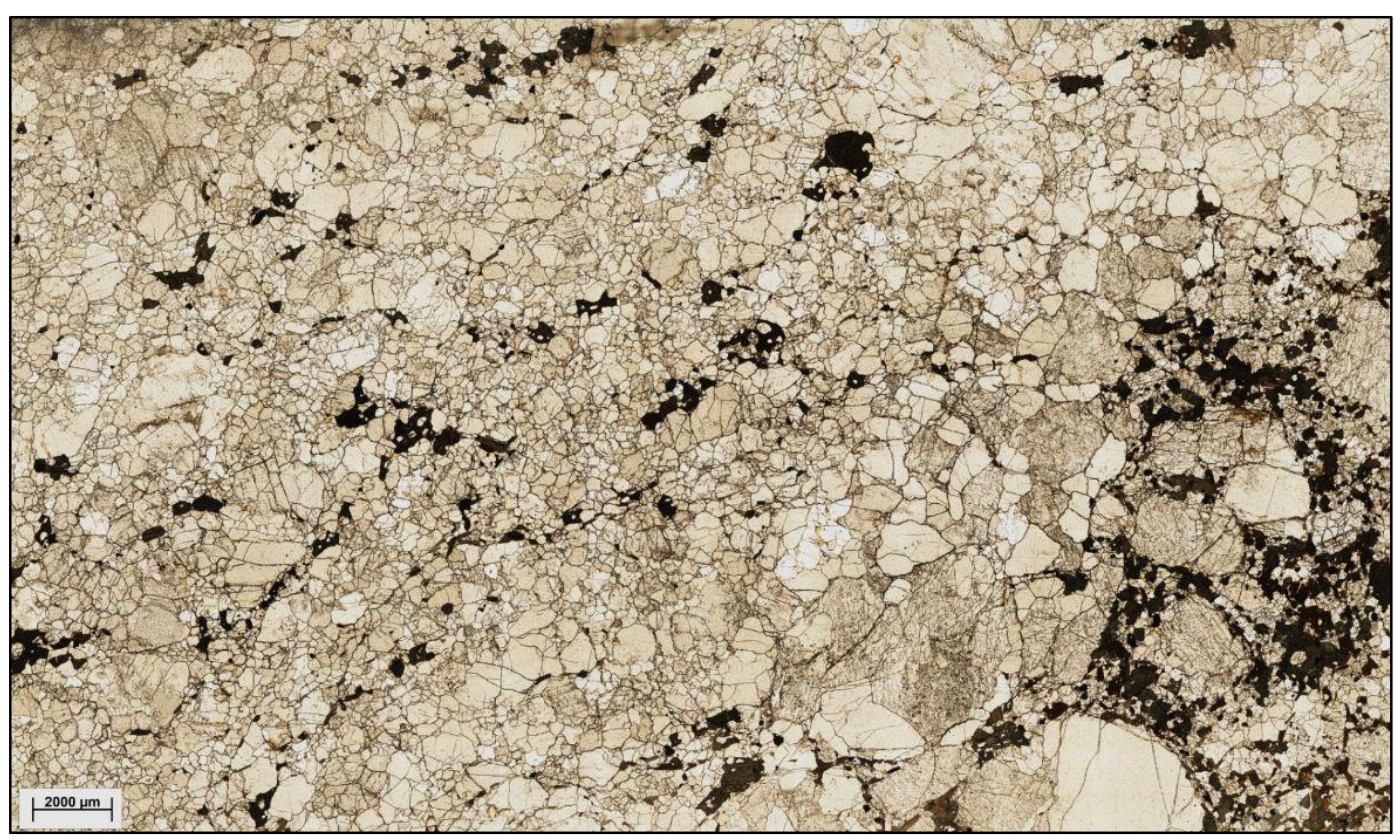

Figura 4.3 - Mosaico da lâmina petrográfica da rocha medianamente alterada (luz transmitida polarizada). 


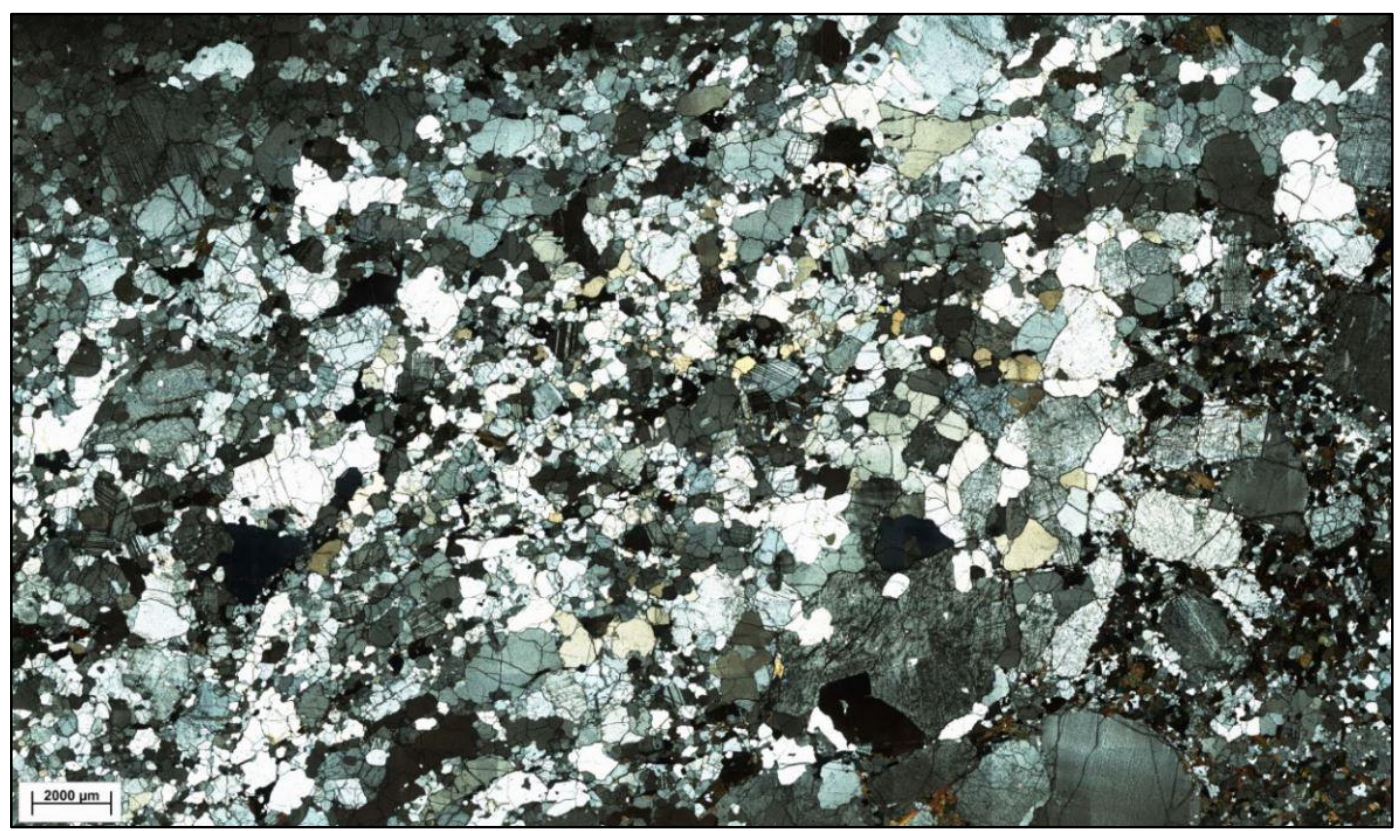

Figura 4.4 - Mosaico da lâmina petrográfica da rocha medianamente alterada (luz transmitida polarizada com nicóis cruzados).

\section{Rocha alterada}

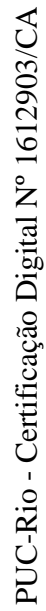

É um gnaisse de composição quartzo-diorítica, com bandamento bem marcado. A rocha é mesocrática, inequigranular com granulometria fina a média. Diversos grãos estão fraturados e recristalizados, principalmente quartzo e plagioclásio, este apresentando geminação pela Lei da Albita e Carlsbad. A composição mineralógica é idêntica à rocha medianamente alterada.

As figuras 4.5 e 4.6 apresentam os mosaicos das lâminas de rocha alterada com e sem luz polarizadas, respectivamente.

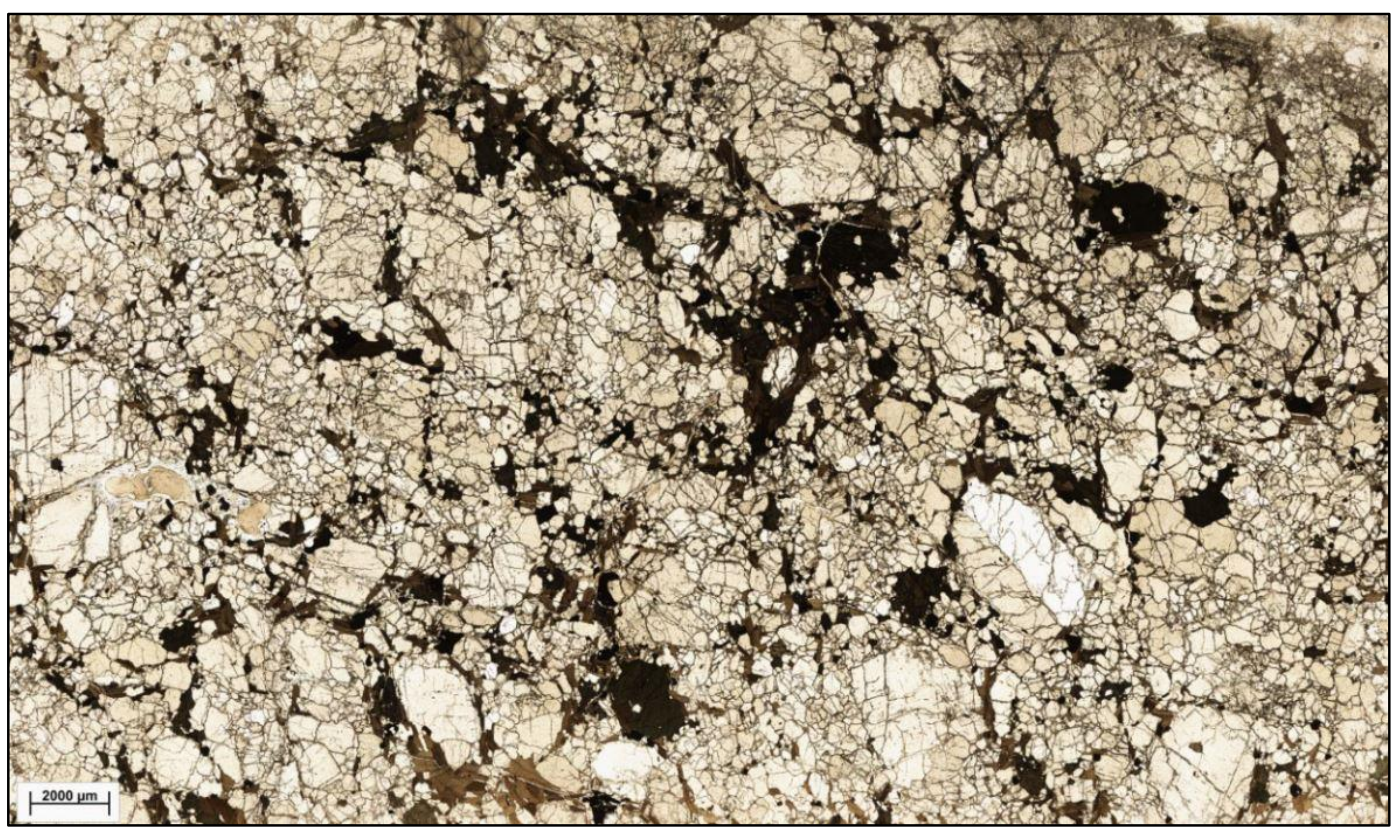

Figura 4.5 - Mosaico da lâmina petrográfica da rocha alterada (luz transmitida polarizada). 


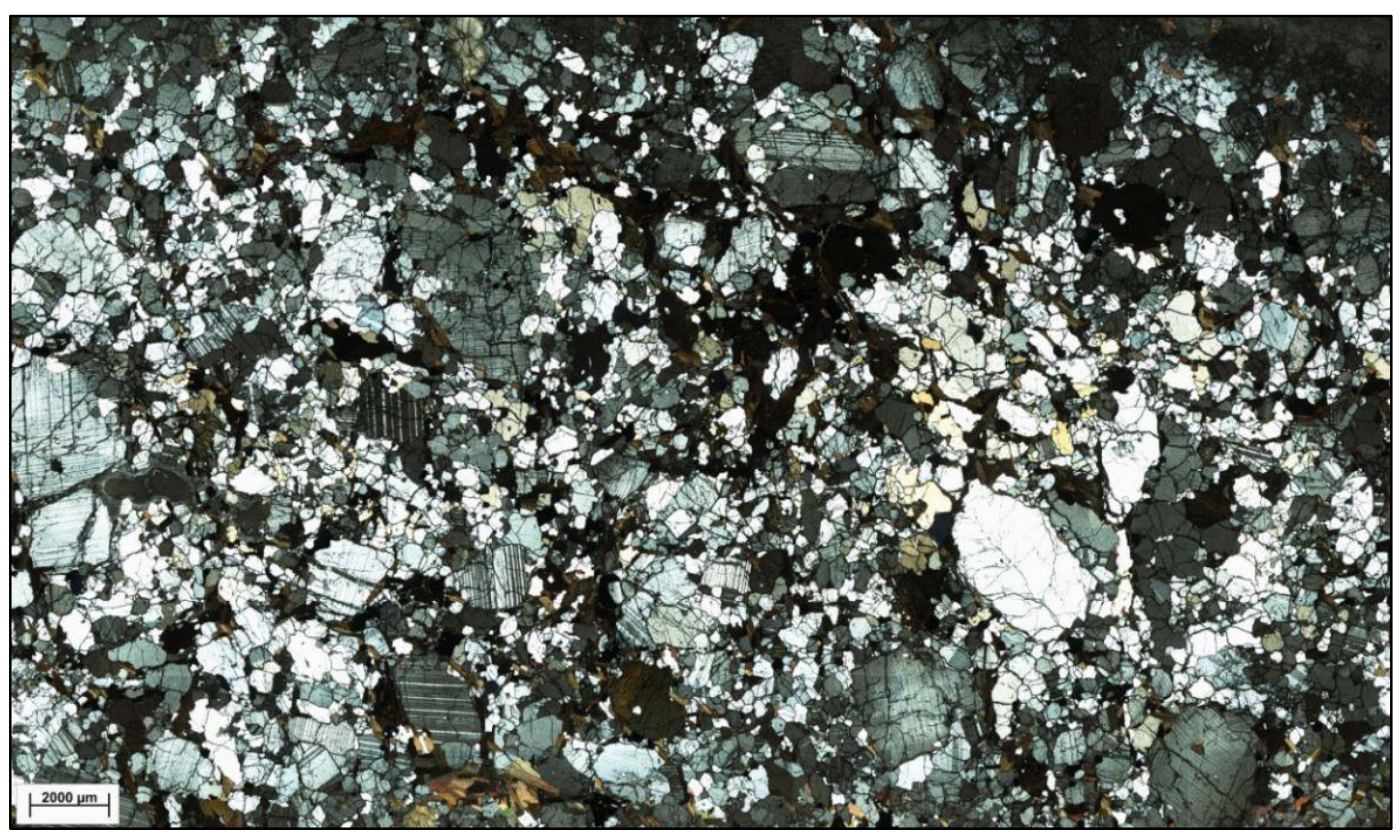

Figura 4.6 - Mosaico da lâmina petrográfica da rocha alterada (luz transmitida polarizada com nicóis cruzados).

Após a análise das lâminas petrográficas, houve a confirmação da descrição inicial das rochas quanto ao seu grau de alteração. Vale ressaltar que a composição mineralógica e a granulometria da rocha sã em relação às demais têm uma pequena diferença. E assim como na descrição macroscópica, identificou-se que as intensidades do bandamento gnáissico entre as rochas sã e medianamente alterada são ligeiramente diferentes.

\section{2 Análise de difração de raio $X$}

Os resultados da difração de raio $\mathrm{X}$ reiteraram a classificação das amostras selecionadas quanto ao grau de alteração. Foram encontrados picos típicos da composição mineralógica das rochas estudadas, coincidindo com os resultados obtidos a partir da análise das lâminas petrográficas.

Foram realizados nove ensaios, sendo três para cada grau. Como os resultados foram similares, a seguir serão apresentados os resultados típicos encontrados para cada grau de alteração (figuras 4.7, 4.8 e 4.9). 


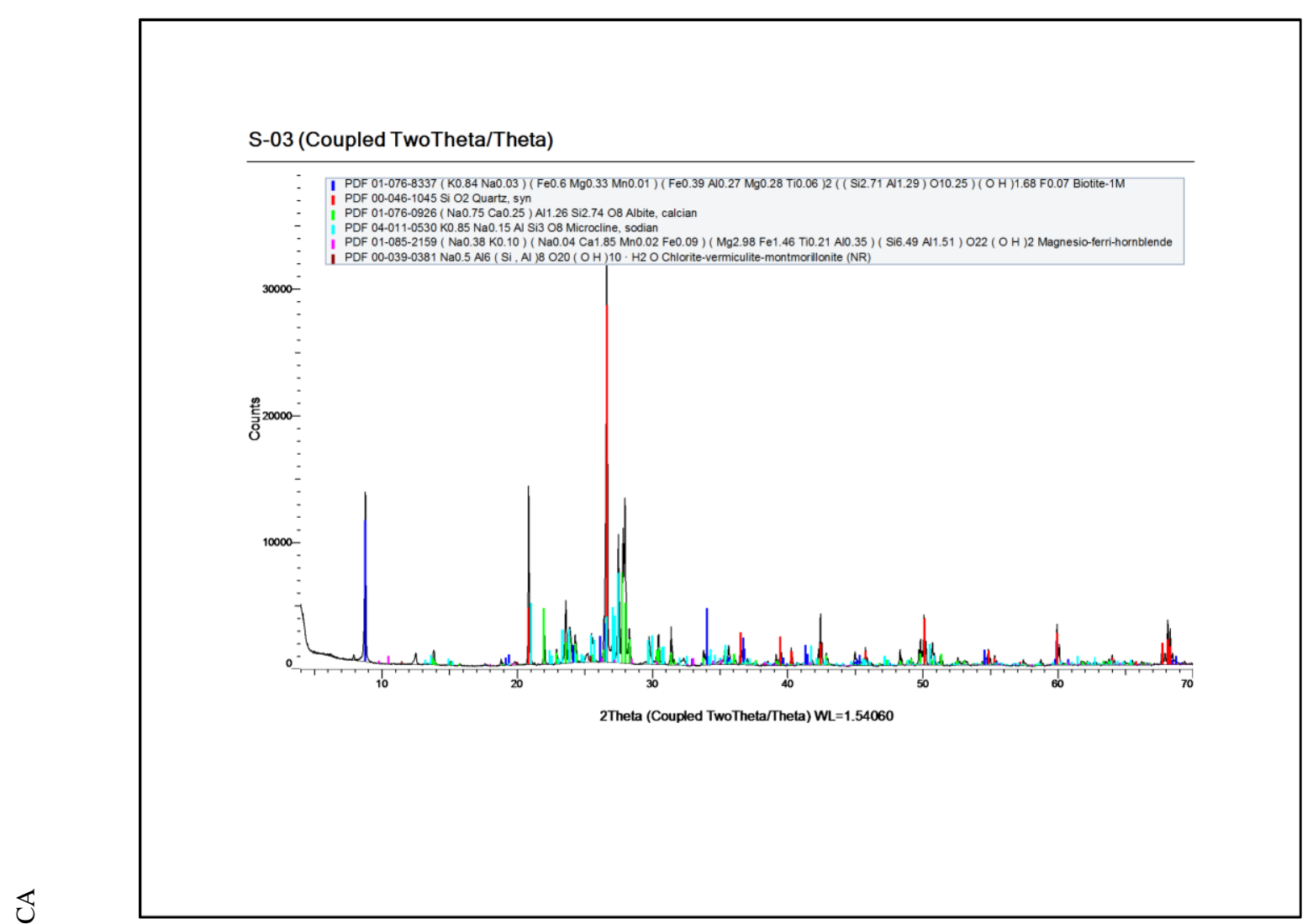

Figura 4.7 - Difratograma da amostra de rocha sã.

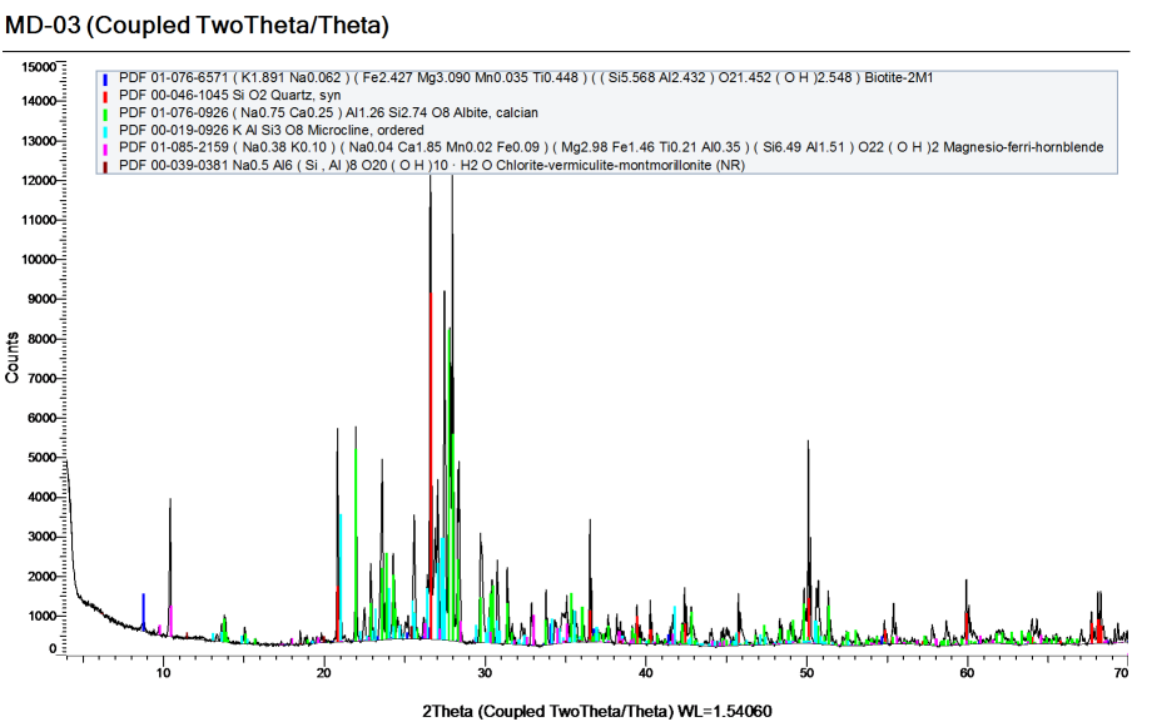

Figura 4.8 - Difratograma da amostra de rocha medianamente alterada. 


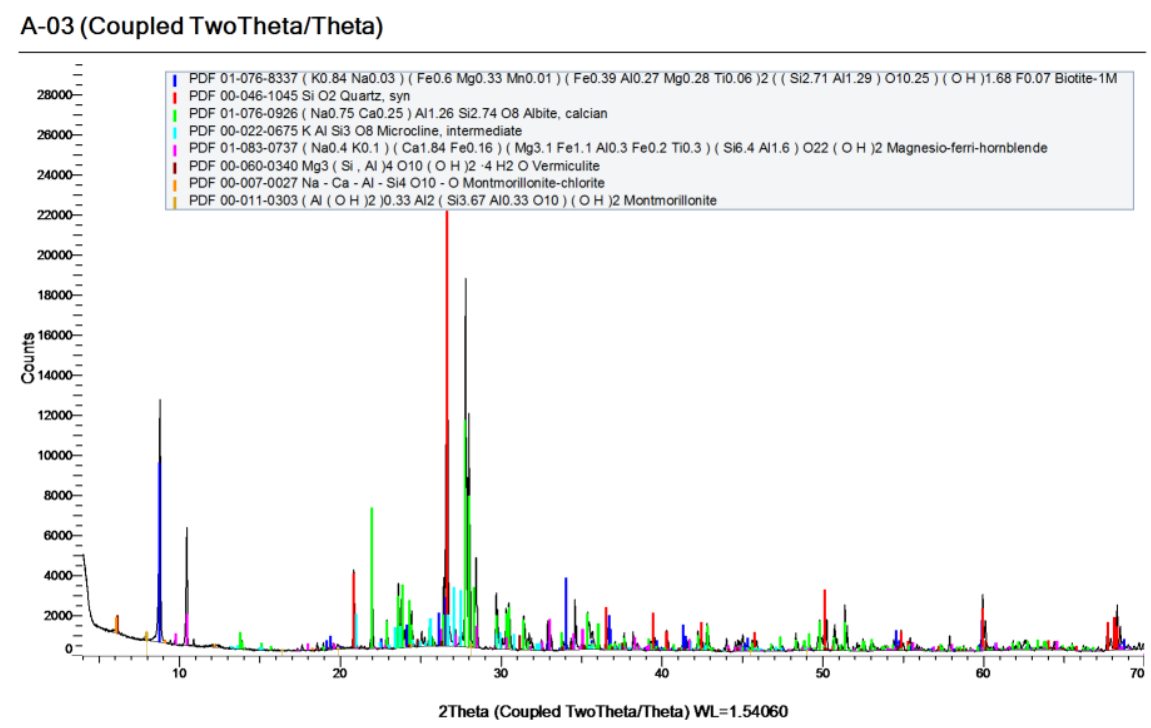

Figura 4.9 - Difratograma da amostra de rocha alterada.

Nos difratogramas da rocha medianamente alterada e, principalmente, nos da rocha alterada, foi possível observar a presença de argilominerais (vermiculita, montimorilonita e clorita), provavelmente fruto da alteração sofrida pela rocha, sendo essa presença mais intensa na rocha alterada.

\section{3}

\section{Caracterização de índices físicos}

No presente trabalho, os índices físicos considerados foram porosidade, massa específica seca e peso específico seco. Esses índices definem as relações básicas da rocha.

Foram caracterizados todos os corpos de prova ensaiados. A seguir, são apresentados os resultados das porosidades (figura 4.10) e dos pesos específicos (figura 4.11) obtidos em função do grau de alteração das rochas. A tabela 4.1 apresenta um resumo com as médias dos resultados para cada grau de alteração. 


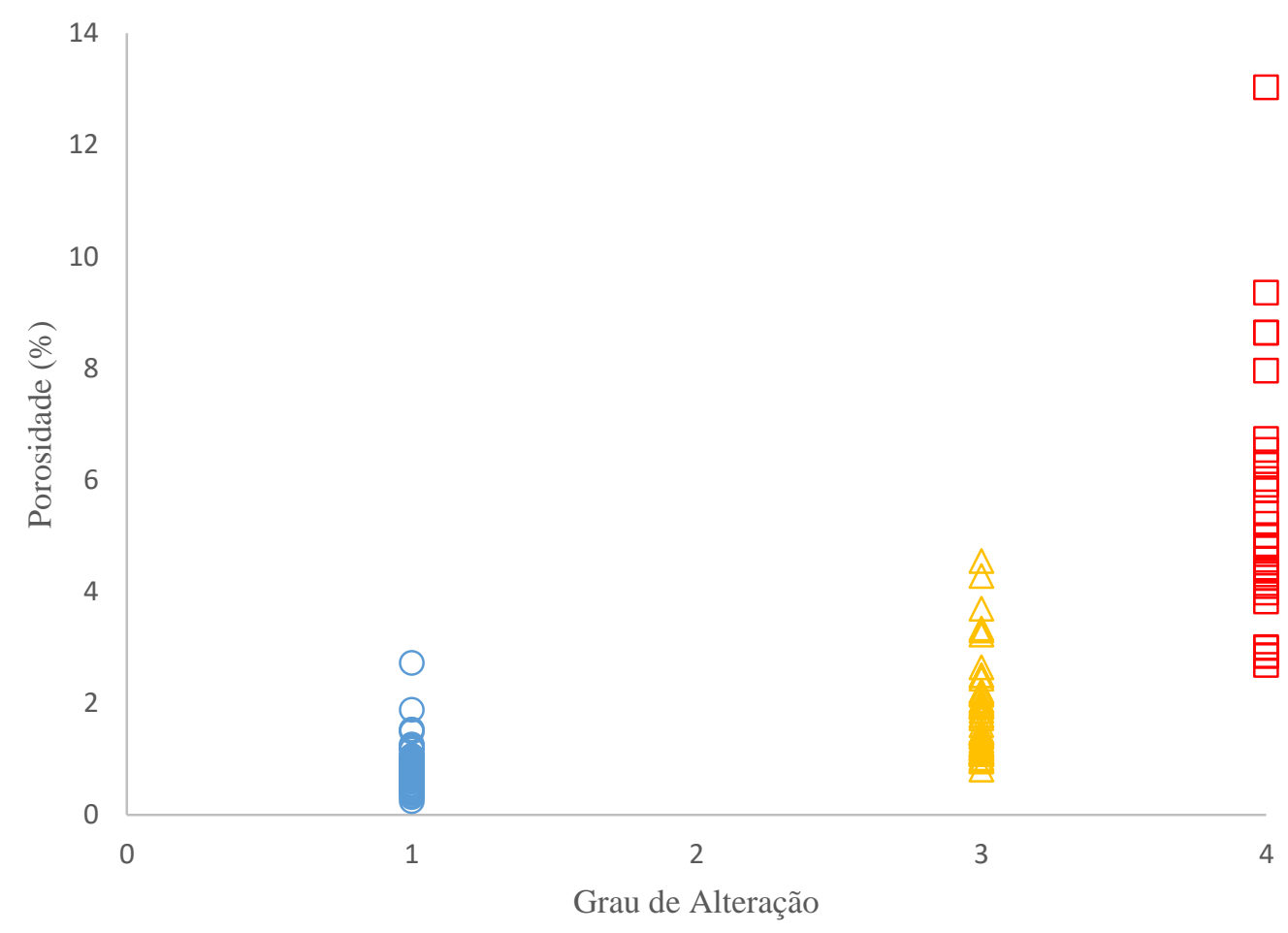

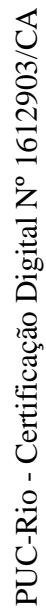

ORocha Sã $\triangle$ Rocha Medianamente Alterada $\square$ Rocha Alterada

Figura 4.10 - Variação da porosidade em função do grau de alteração das rochas.

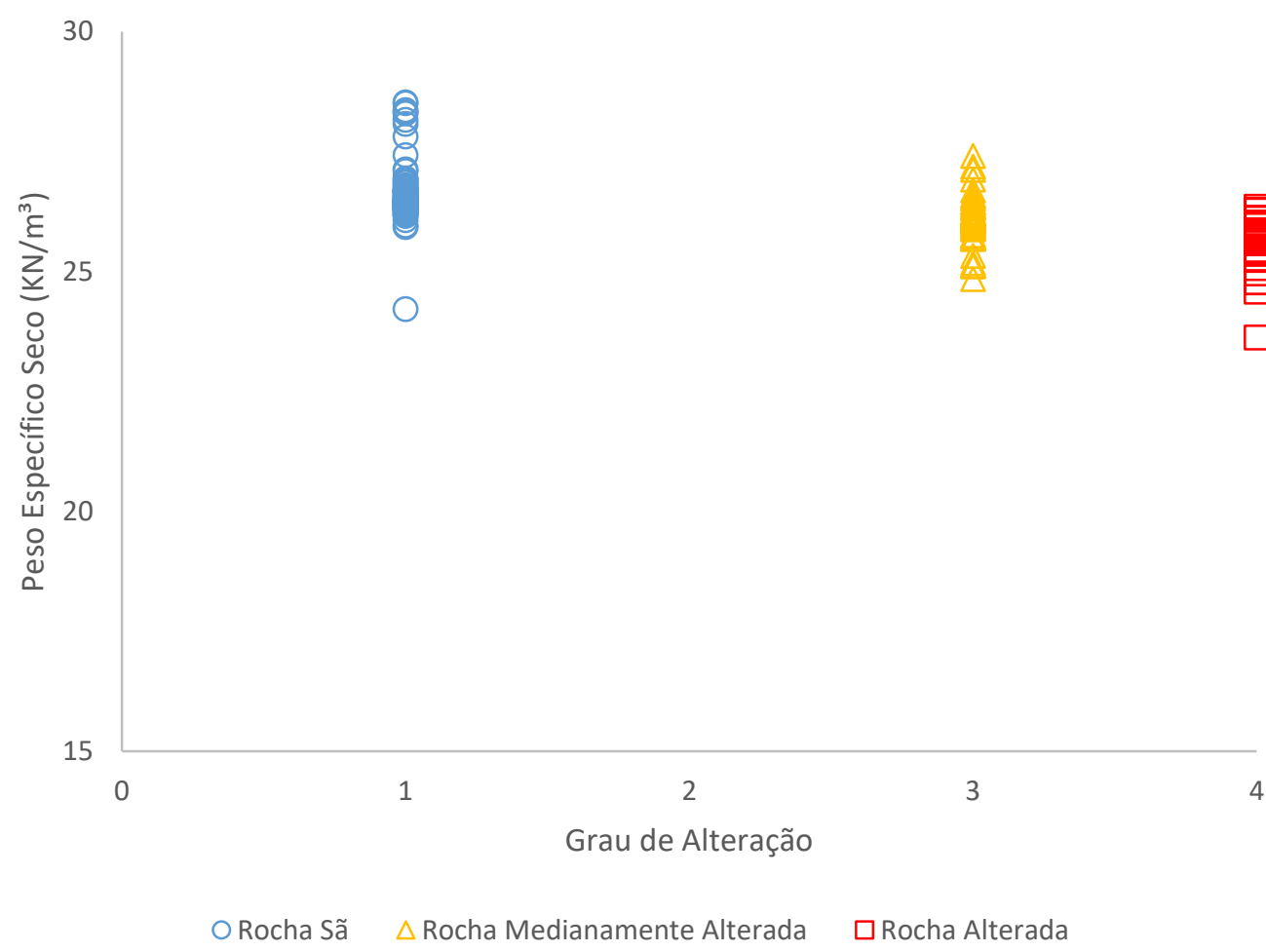

Figura 4.11 - Variação do peso específico seco em função do grau de alteração das rochas. 
Tabela 4.1 - Resumo da caracterização dos índices físicos.

\begin{tabular}{ccccc}
\hline \multicolumn{2}{c}{ Grau de Alteração } & $\begin{array}{c}\text { Porosidade } \\
(\%)\end{array}$ & $\begin{array}{c}\text { Massa } \\
\text { Específica Seca } \\
\left(\mathrm{g} / \mathrm{cm}^{3}\right)\end{array}$ & $\begin{array}{c}\text { Peso Específico } \\
\text { Seco }\left(\mathrm{kN} / \mathrm{m}^{3}\right)\end{array}$ \\
\hline Rocha Sã & Média & 0,79 & 2,72 & 26,61 \\
$\begin{array}{c}\text { Rocha } \\
\text { Medianamente } \\
\text { Alterada }\end{array}$ & Média & 1,75 & 2,2 & 2,2 \\
Rocha & Média & 5,41 & 2,66 & 26,11 \\
Alterada & $C V(\%)$ & 0,4 & 1,7 & 1,7 \\
\hline
\end{tabular}

Em geral, rochas ígneas e metamórficas ortoderivadas não apresentam altas porosidades quando comparadas com outros litotipos, por exemplo rochas sedimentares. Tal fato é corroborado pela análise de índices realizada.

Como mencionado anteriormente, a porosidade aumenta à medida que o grau de alteração aumenta. Isto ocorre, pois, com o incremento do intemperismo, as rochas sofrem desagregação e decomposição. As porosidades médias das rochas medianamente alteradas e das rochas alteradas tiveram um aumento em relação às rochas alteradas de $121,5 \%$ e $584,8 \%$, respectivamente.

A massa específica seca e, consequentemente, o peso específico seco diminuem conforme a rocha vai se alterando. No entanto, diferente da porosidade, onde a variação encontrada entre os litotipos foi muito grande, esses parâmetros apresentaram pequena variação nos resultados obtidos. A média do peso específico seco das rochas sãs foi de $26,61 \mathrm{kN} / \mathrm{m}^{3}$, enquanto as rochas alteradas obtiveram 25,64 kN/m³, gerando uma redução de 3,7\%. Já as rochas medianamente alteradas tiveram uma redução de $1,9 \%$.

No gráfico da figura 4.10, é possível observar uma grande variação da porosidade das rochas alteradas, com $13,03 \%$ e 2,68\% de valores máximos e mínimos, respectivamente. Na tabela 4.1, os valores obtidos nos coeficientes de variação dos parâmetros calculados são baixos, indicando, assim, que os resultados obtidos apresentaram pouca dispersão e estavam próximos da média obtida.

A seguir, na figura 4.12, é apresentado o gráfico do peso específico em função da porosidade dos corpos de prova ensaiados. 


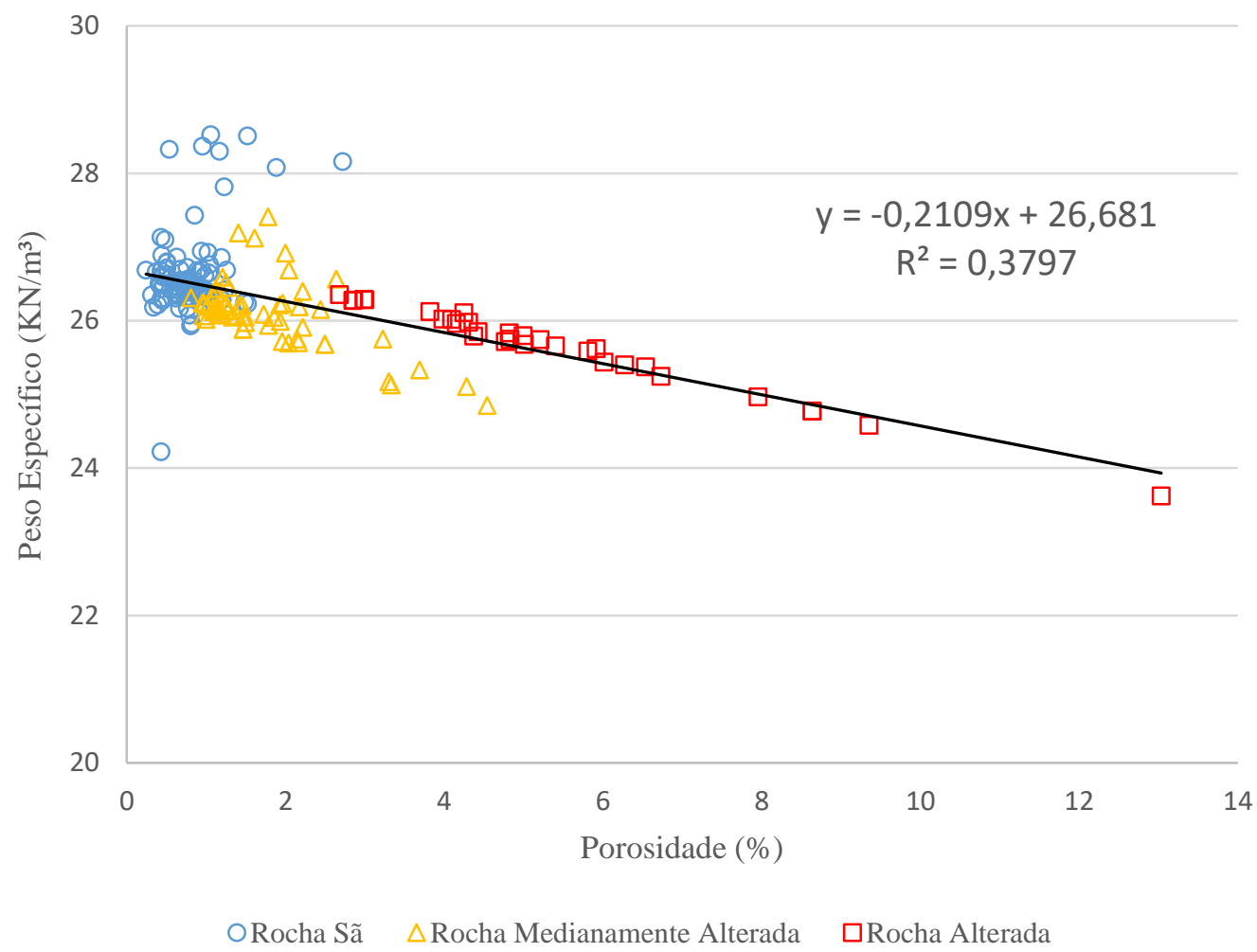

Figura 4.12 - Variação do peso específico seco em função da porosidade.

Peso específico seco e a porosidade são parâmetros que têm uma relação linear. No gráfico da figura 4.12, é possível observar a dispersão citada anteriormente da porosidade das rochas alteradas. Outro fato representado no gráfico que merece destaque é a interseção de amostras medianamente alteradas tanto com rochas sãs como com rochas alteradas. Isso mostra que, além de estarem numa fase de transição, as amostras apresentavam uma diferença entre si, algumas mais sãs e outras mais alteradas.

Menezes Filho (1993) e Santos (2004) apresentaram valores médios das propriedades físicas de gnaisses facoidais da cidade do Rio de Janeiro, através das sugestões da ISRM (1981). Apesar de as litologias apresentarem protólitos diferentes das rochas analisadas no presente trabalho, elas são semelhantes, sendo possível realizar uma comparação entre os resultados. As tabelas 4.2 e 4.3 apresentam os valores médios das porosidades e dos pesos específicos secos, respectivamente. 
Tabela 4.2 - Resultados médios das porosidades encotradas no presente trabalho, em Santos (2004) e Menezes filho (1993).

\begin{tabular}{cccc} 
Grau de Alteração & Porosidade (\%) & $\begin{array}{c}\text { Santos (2004) } \\
\text { Porosidade (\%) }\end{array}$ & $\begin{array}{c}\text { Menezes Filho (1993) } \\
\text { Porosidade (\%) }\end{array}$ \\
\hline $\begin{array}{c}\text { Rocha Sã } \\
\text { Rocha Levemente } \\
\text { Alterada } \\
\begin{array}{c}\text { Rocha Medianamente } \\
\text { Alterada }\end{array}\end{array}$ & 0,79 & 1,03 & 0,75 \\
Rocha Alterada & 1,75 & 2,76 & 1,65 \\
& 5,41 & 4,81 & 3,78 \\
\end{tabular}

Tabela 4.3 - Resultados médios dos pesos específicos secos encontrados no presente trabalho, em Santos (2004) e Menezes filho (1993).

\begin{tabular}{cccc}
\hline Grau de Alteração & $\begin{array}{c}\text { Peso Específico } \\
\text { Seco }\left(\mathrm{kN} / \mathrm{m}^{3}\right)\end{array}$ & $\begin{array}{c}\text { Santos (2004) } \\
\text { Peso Específico } \\
\text { Seco }\left(\mathrm{kN} / \mathrm{m}^{3}\right)\end{array}$ & $\begin{array}{c}\text { Menezes Filho (1993) } \\
\text { Peso Específico Seco } \\
\left(\mathrm{kN} / \mathrm{m}^{3}\right)\end{array}$ \\
\hline $\begin{array}{c}\text { Rocha Sã } \\
\begin{array}{c}\text { Rocha Levemente } \\
\text { Alterada }\end{array}\end{array}$ & 26,61 & 27,10 & 26,45 \\
$\begin{array}{c}\text { Rocha Medianamente } \\
\text { Alterada }\end{array}$ & 26,11 & 26,66 & 26,20 \\
Rocha Alterada & 25,64 & 26,00 & 25,35 \\
& & - & 24,05
\end{tabular}

Como mencionado, os litotipos são diferentes, porém ambos são rochas gnáissicas ortederivadas (protólito ígneo). O gnaisse facoidal tem sua composição formada por plagioclásio, quartzo, microclina e biotita. O gnaisse facoidal apresenta mais microclina que as rochas gnáissicas estudadas no presente trabalho, além de ter uma granulometria mais grosseira (porfiroblastos de microclina).

No geral, os resultados obtidos foram similares aos resultados dos respectivos trabalhos. A rocha sã obteve valores mais próximos a Menezes Filhos (1993), tanto de porosidade quanto de peso específico seco.

A porosidade obtida para a rocha medianamente alterada foi mais próxima da encontrada para rocha levemente alterada em Menezes Filho (1993) e Santos (2004). Já o peso específico seco obtido foi próximo ao encontrado em Santos (2004). 
Nas rochas alteradas houve uma diferença um pouco mais significativa. Tal fato pode ter sido influenciado pela diferença de composição mineralógica, pois os produtos gerados pela alteração são diferentes.

\section{4}

\section{Ensaio esclerométrico (martelo de Schmidt)}

Durante o ensaio de esclerometria, é essencial que o corpo de prova esteja estável, por isso foi realizado na rocha in situ, quando possível, e/ou nos blocos antes da retirada dos corpos de prova. Em função das dimensões e do peso, os blocos se mantinham estáveis.

O ensaio foi realizado sempre com o martelo de Schmidt a $90^{\circ}$ da superfície da rocha. Foram realizadas 40 (quarenta) leituras para cada unidade (bloco ou in situ), sendo descartados duas leituras em cada uma das extremidades do espaço amostral, perfazendo, assim, um total de 36 (trinta e seis) leituras (Aydin, 2009).

Diante das irregularidades das rochas no campo e dos blocos, aliadas à dificuldade de movimentação em função do peso, não foi possível realizar o ensaio com controle da direção da foliação.

A seguir são apresentados os resultados obtidos nos ensaios realizados. A figura 4.13 apresenta os valores do índice Q obtidos em função do grau de alteração das rochas. A tabela 4.4 apresenta um resumo dos resultados do ensaio esclerométrico, onde são apresentados os índices Q médios e os valores de resistência à compressão simples calculados em função do índice Q. 


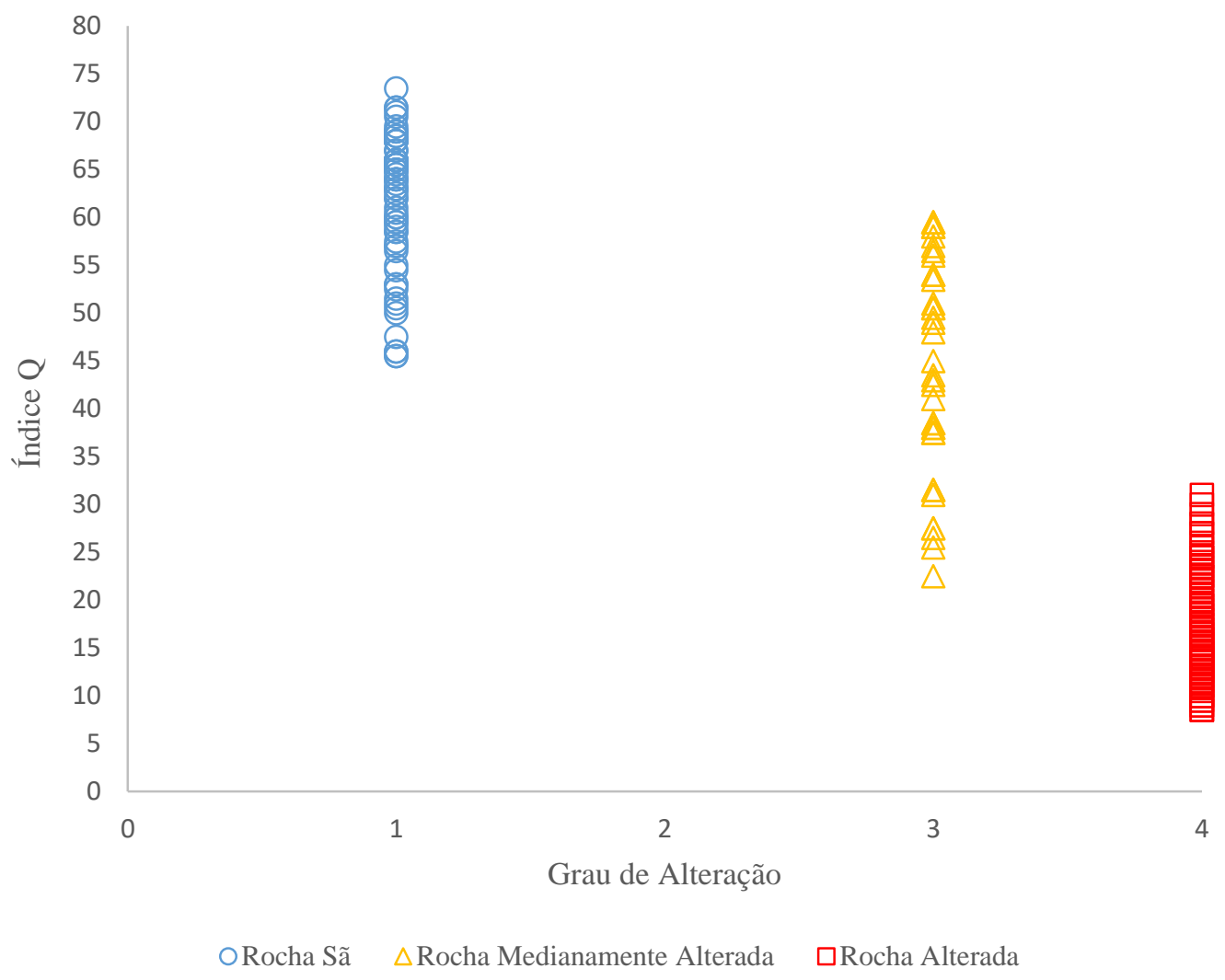

Figura 4.13 - Variação do índice Q do Martelo de Schmidt em função do grau de alteração das rochas.

Tabela 4.4 - Resumo dos resultados do ensaio esclerométrico.

\begin{tabular}{ccccc}
\hline \multicolumn{2}{c}{ Grau de Alteração } & Qmédio & $\begin{array}{c}C V \\
(\%)\end{array}$ & $\begin{array}{c}\text { UCS } \\
\text { referente ao } \\
\text { Q médio }\end{array}$ \\
\hline \multirow{2}{*}{ Rocha Sã } & in situ & 64,58 & 6,9 & 133,27 \\
bloco & 59,19 & 13,7 & 91,39 \\
$\begin{array}{c}\text { Recha } \\
\text { Alterada }\end{array}$ & in situ & - & - & - \\
Rocha Alterada & bloco & 44,19 & 25,5 & 31,98 \\
& bloco situ & 17,63 & 27,0 & 4,98 \\
\hline
\end{tabular}

Os resultados obtidos confirmaram as expectativas: valores muito baixos para a rocha alterada, intermediários para a medianamente alterada e altos para a rocha sã.

Foi observada, também, uma maior variação do índice Q para as rochas medianamente alterada e alterada quando comparada com a rocha sã, conforme o coeficiente de variação medido. 


\section{5 Ensaio de resistência à compressão puntiforme}

Foram realizados 108 ensaios, sendo 59 (sessenta e nove) em rocha sã (18 diametrais e 41 axiais), 34 (trinta e quatro) em rocha medianamente alterada (9 diametrais e 25 axiais) e 15 (quinze) em rocha alterada (5 diametrais e 10 axiais).

$\mathrm{Na}$ figura 4.14 são apresentados os resultados obtidos no point load test. Onde é possível comparar os valores do índice Is, tanto dos ensaios diametrais como dos ensaios axiais, em função do grau de alteração dos corpos de prova ensaiados.

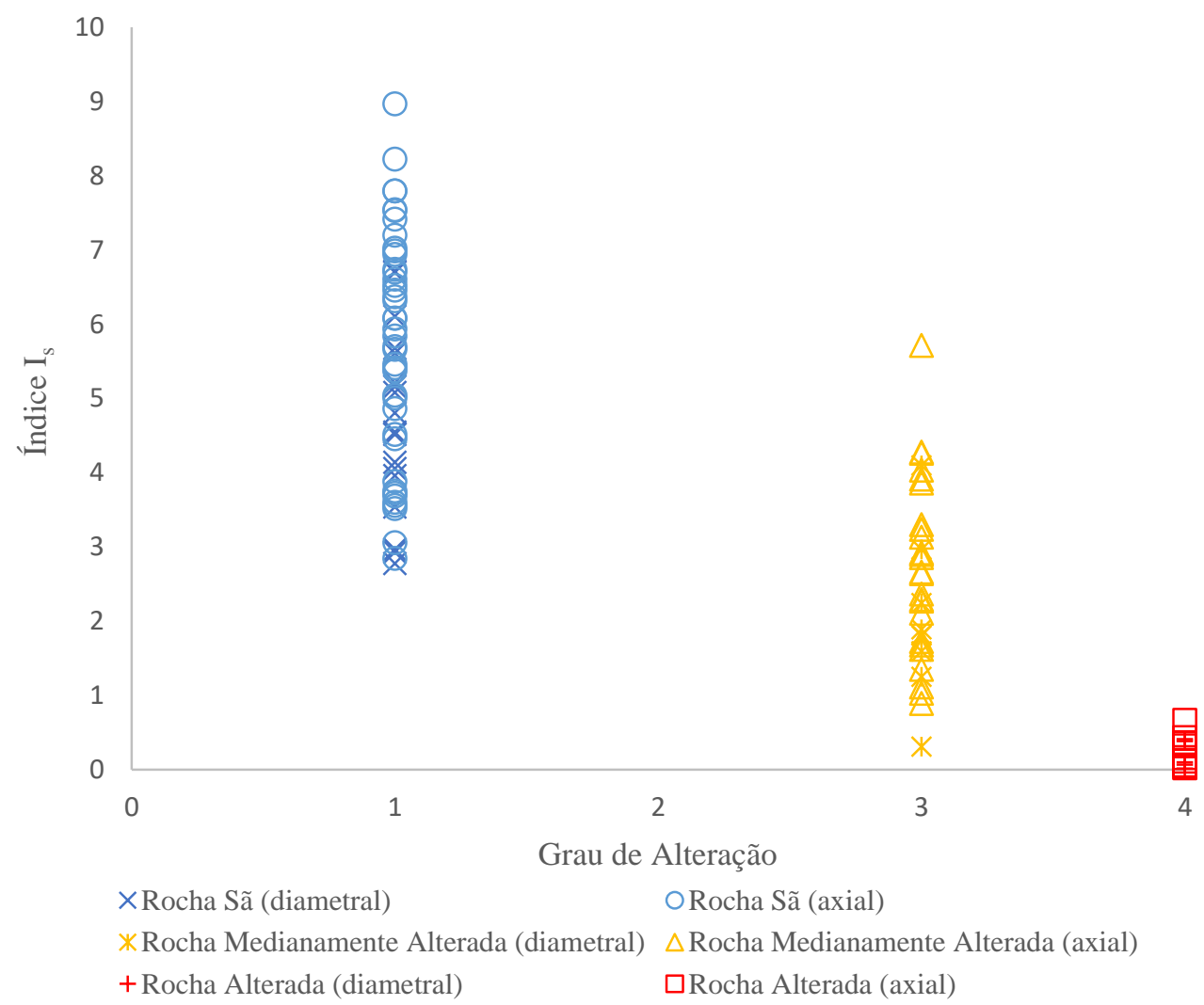

Figura 4.14 - Variação dos índices de resistências puntiformes (axial e diametral) em função do grau de alteração das rochas.

O gráfico da figura 4.14 apresenta uma grande variação de valores do índice Is para rochas sãs. Assim como no ensaio esclerométrico, a resistência obtida diminuiu à medida que o grau de alteração aumentou.

A tabela 4.5 apresenta um resumo dos resultados obtidos nos ensaios realizados. A figura 4.15 apresenta a variação do índice de resistência puntiforme (Is) em função da porosidade. 
Tabela 4.5 - Resumo dos resultados do ensaio de Point Load.

\begin{tabular}{ccccc}
\hline \multicolumn{2}{c}{ Grau de Alteração } & & $\mathrm{I}_{\mathrm{s}}(\mathrm{MPa})$ & $\sigma_{\mathrm{s}}(\mathrm{MPa})$ \\
\hline \multirow{4}{*}{ Rocha Sã } & \multirow{2}{*}{ Diametral } & Média & 4,70 & 112,69 \\
& & $C V(\%)$ & 25,8 & - \\
& \multirow{4}{*}{ Axial } & Média & 5,76 & 138,31 \\
Rocha & \multirow{2}{*}{ Diametral } & $C V(\%)$ & 27,0 & - \\
Medianamente & & Média & 2,00 & 47,97 \\
Alterada & \multirow{2}{*}{ Axial } & Média & 2,73 & 65,47 \\
& & $C V(\%)$ & 43,6 & - \\
\multirow{3}{*}{ Rocha Alterada } & \multirow{2}{*}{ Diametral } & Média & 0,20 & 4,74 \\
& & $C V(\%)$ & 94,8 & - \\
& \multirow{2}{*}{ Axial } & Média & 0,25 & 6,09 \\
& & $C V(\%)$ & 82,3 & - \\
\hline
\end{tabular}

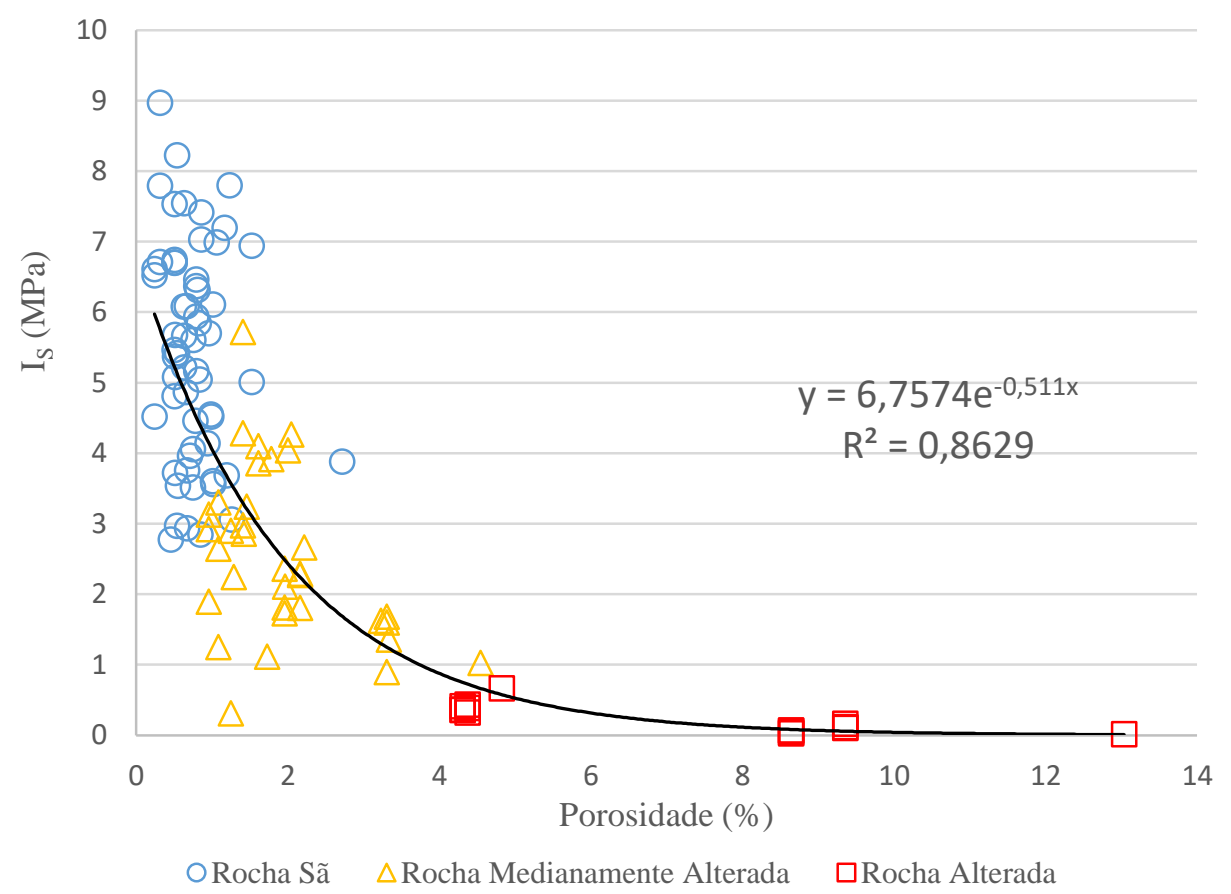

Figura 4.15 - Variação dos índices de resistências puntiformes em função da porosidade.

$\mathrm{Na}$ tabela 4.5 é possível observar que a resistência média obtida no ensaio axial para as rochas medianamente alteradas foi $52,7 \%$ menor que a obtida para rochas sãs, e 95,6\% menor para as rochas alteradas. Vale ressaltar que, em geral, a resistência diametral é menor que a axial, em função da configuração geométrica do ensaio.

No gráfico da figura 4.15, é possível identificar uma relação não linear entre o índice IS obtido no Point Load Test e a porosidade das amostras ensaiadas. Neste gráfico, não houve a separação de ensaios diametrais e axiais. 


\section{6 Ensaio de resistência à compressão uniaxial}

Foram ensaiados 15 (quinze) corpos de prova, sendo 5 (cinco) de cada grau de alteração. Em virtude das dificuldades apresentadas na amostragem da rocha alterada, não foi possível manter a relação do comprimento-diâmetro 2,5 a 3,0 sugerida pela ISRM (1979a). As amostras A-01, A-04 e A-05 tiveram, respectivamente, 114,90 mm, 109,90 mm e 112,80 mm de comprimento.

A seguir são apresentados os resultados obtidos em função do grau de alteração (figura 4.16). Na figura 4.17 é possível observar as curvas típicas de cada classe no gráfico tensão-deformação (amostras utilizadas: S-06, MD-06 e A06). A figura 4.18 apresenta os corpos de prova rompidos após o ensaio. A tabela 4.6 contém um resumo com as resistências à compressão uniaxial, as deformações e os módulos de elasticidade dos corpos de prova ensaiados.

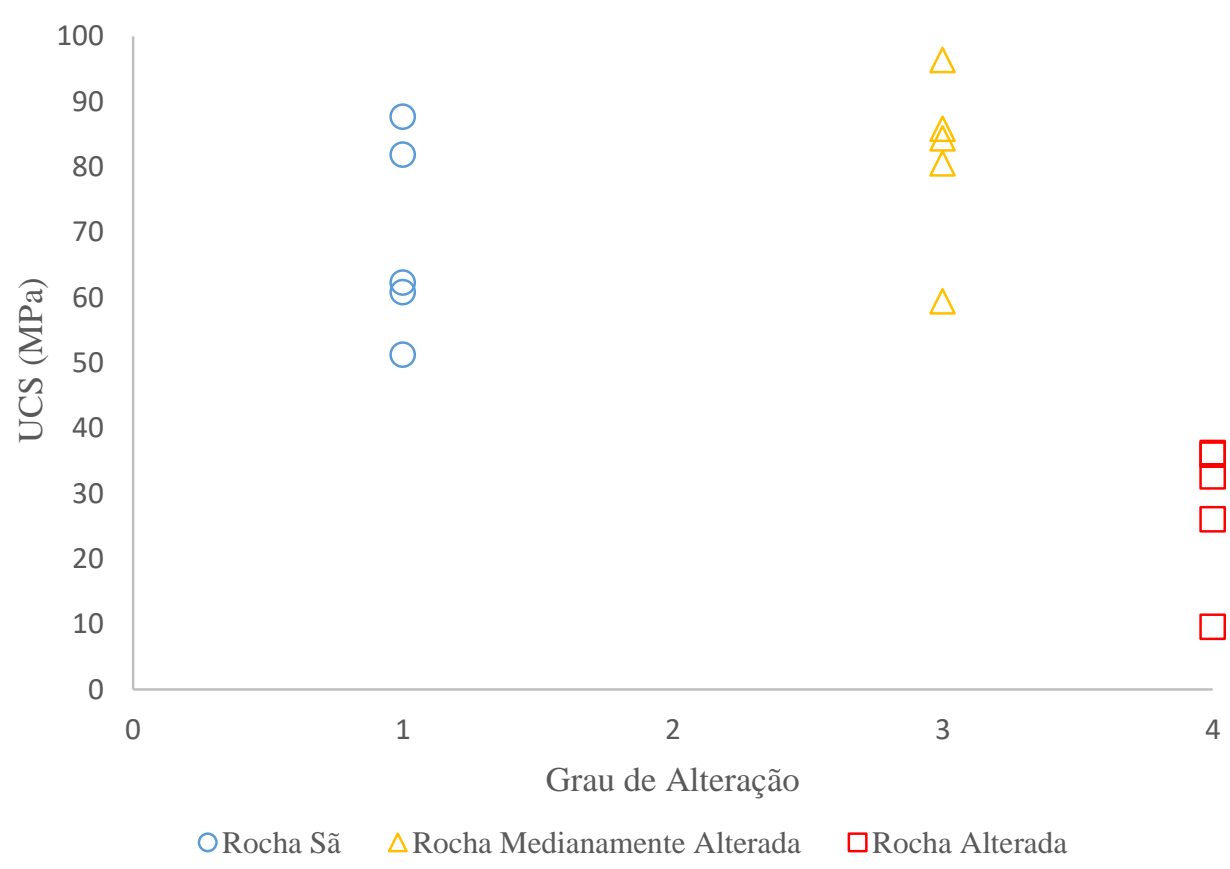

Figura 4.16 - Resultado do ensaio de compressão uniaxial em função do grau de alteração das rochas. 


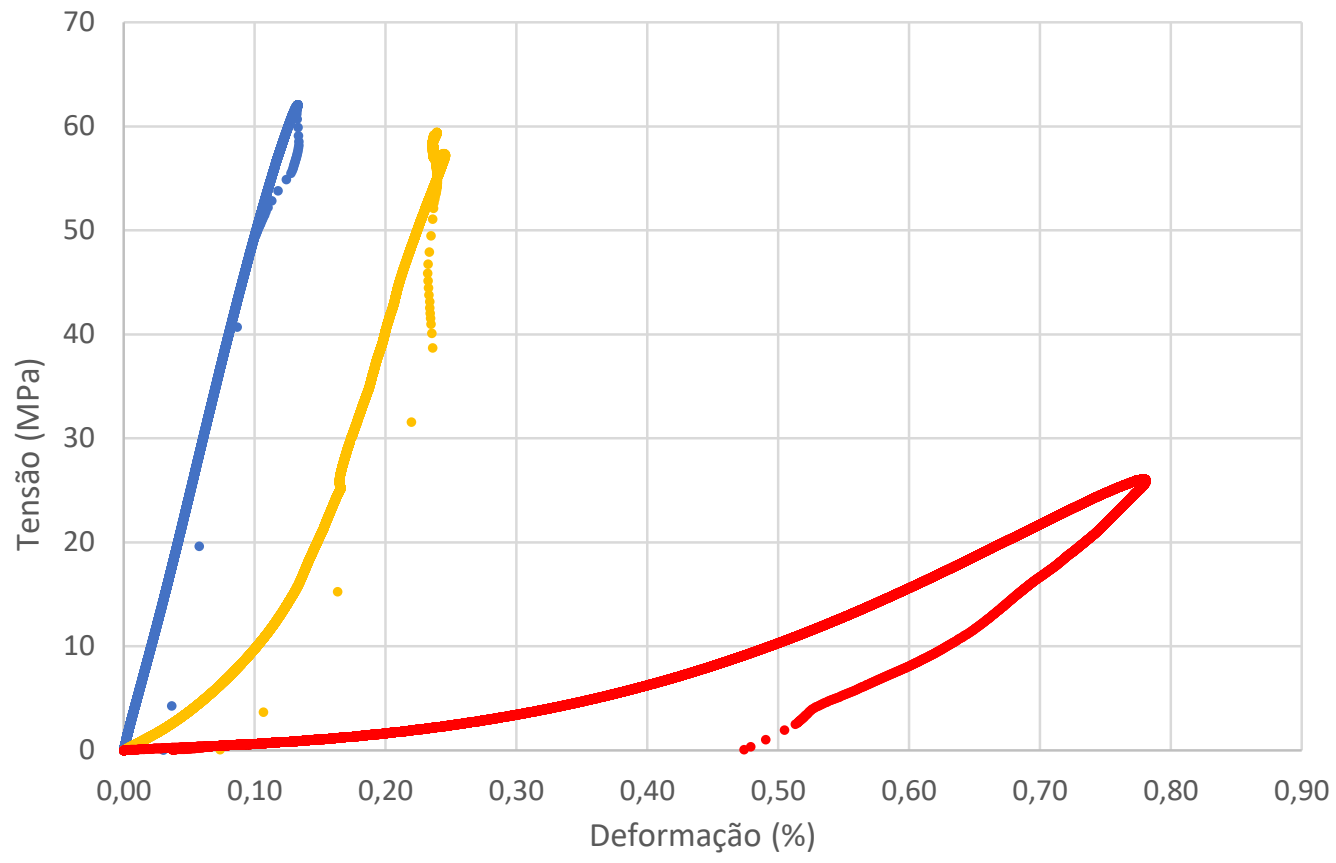

- Rocha Sã • Rocha Medianamente Alterada • Rocha Alterada

Figura 4.17 - Curvas tensão-deformação típicas dos litotipos estudados.

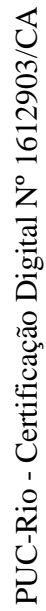

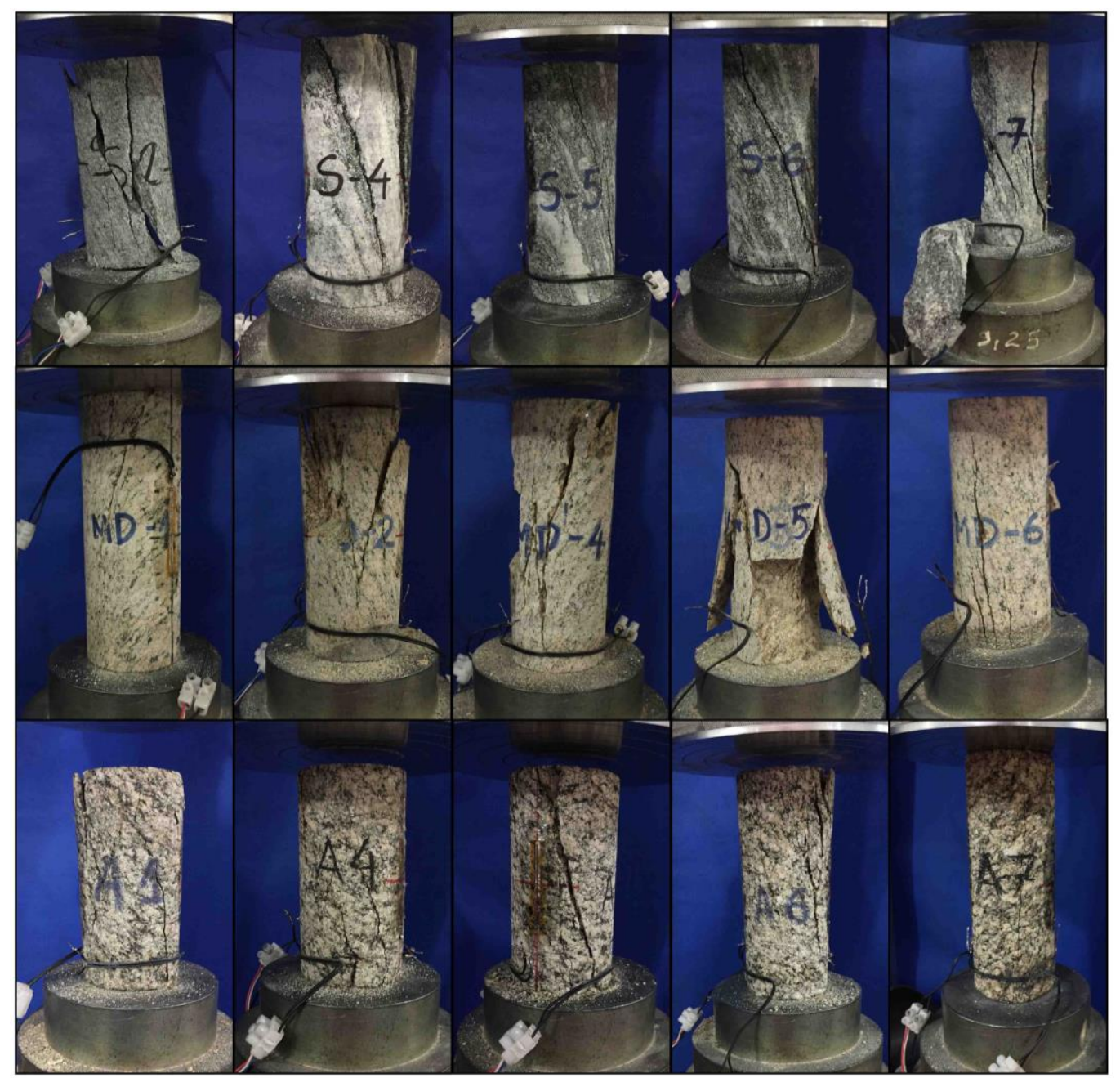

Figura 4.18 - Corpos de prova rompidos após o ensaio de compressão uniaxial. 
Tabela 4.6 - Resumo dos resultados do ensaio de compressão uniaxial.

\begin{tabular}{|c|c|c|c|c|c|c|}
\hline \multicolumn{3}{|c|}{ Corpo de Prova } & \multirow{2}{*}{$\begin{array}{c}\begin{array}{c}\text { UCS } \\
(\mathrm{MPa})\end{array} \\
87,67\end{array}$} & \multirow{2}{*}{$\begin{array}{c}\text { Deformação } \\
\%\end{array}$} & \multirow{2}{*}{$\begin{array}{c}E \\
(\mathrm{GPa}) \\
59,27\end{array}$} & \multirow{2}{*}{$\begin{array}{c}\text { E/UCS } \\
676\end{array}$} \\
\hline \multirow{7}{*}{ Rocha Sã } & 1 & S-02 & & & & \\
\hline & 2 & S-04 & 60,84 & 0,09 & 54,44 & 895 \\
\hline & 3 & S-05 & 51,28 & 0,09 & 45,74 & 892 \\
\hline & 4 & S-06 & 62,31 & 0,13 & 51,52 & 827 \\
\hline & 5 & S-07 & 81,91 & 0,14 & 61,56 & 751 \\
\hline & & hédia & 68,80 & 0,11 & 54,51 & 808 \\
\hline & & $V(\%)$ & 22,3 & 23,7 & 11,5 & 11,7 \\
\hline \multirow{7}{*}{$\begin{array}{c}\text { Rocha } \\
\text { Medianamente } \\
\text { Alterada }\end{array}$} & & MD-01 & 80,57 & 0,33 & 27,02 & 335 \\
\hline & & MD-02 & 85,88 & 0,27 & 31,23 & 364 \\
\hline & & MD-04 & 96,37 & 0,30 & 30,10 & 312 \\
\hline & & MD-05 & 84,36 & 0,27 & 26,81 & 318 \\
\hline & & MD-06 & 59,42 & 0,24 & 21,68 & 365 \\
\hline & & Média & 81,32 & 0,28 & 27,37 & 339 \\
\hline & & $V(\%)$ & 16,7 & 11,5 & 13,6 & 7,3 \\
\hline \multirow{7}{*}{ Rocha Alterada } & 1 & $\mathrm{~A}-01$ & 32,62 & 0,51 & 12,12 & 372 \\
\hline & 2 & A-04 & 36,21 & 0,71 & 7,35 & 203 \\
\hline & 3 & $A-05$ & 35,93 & 0,78 & 6,96 & 194 \\
\hline & 4 & A-06 & 26,07 & 0,78 & 5,21 & 200 \\
\hline & & $A-07$ & 9,58 & 0,62 & 1,82 & 191 \\
\hline & & hédia & 28,08 & 0,68 & 6,69 & 232 \\
\hline & & $V(\%)$ & 39,6 & 17,4 & 55,8 & 33,8 \\
\hline
\end{tabular}

Os resultados mostram que as rochas medianamente alteradas, apesar de apresentarem maior deformação e módulos de elasticidade mais baixos que as rochas sãs, têm resistência à compressão uniaxial igual ou até mesmo superior, obtendo uma média superior às rochas sãs.

Vale ressaltar que, as rochas medianamente alteradas apresentaram uma granulometria fina a média e composição quartzo-diorítica, sem bandamento gnáissico bem marcado, por vezes incipiente. As rochas sãs já apresentam uma granulometria fina, composição granodiorítica e possuem o bandamento gnáissico bem marcado. Tais características associadas ao efeito escala, resultante do comprimento de aproximadamente $135 \mathrm{~mm}$, pode ter gerado resultados de compressão uniaxial elevados, equiparados à rocha sã.

A partir dos resultados obtidos nos outros ensaios, foi possível realizar uma série de correlações. A figura 4.19 apresenta a variação da resistência à compressão uniaxial em função da porosidade. A figura 4.20 apresenta a variação da relação módulo de elasticidade/resistência à compressão uniaxial em função da 
porosidade. Na tabela 4.7 é feita a comparação dos resultados de compressão uniaxial obtidos diretamente e indiretamente no presente trabalho.

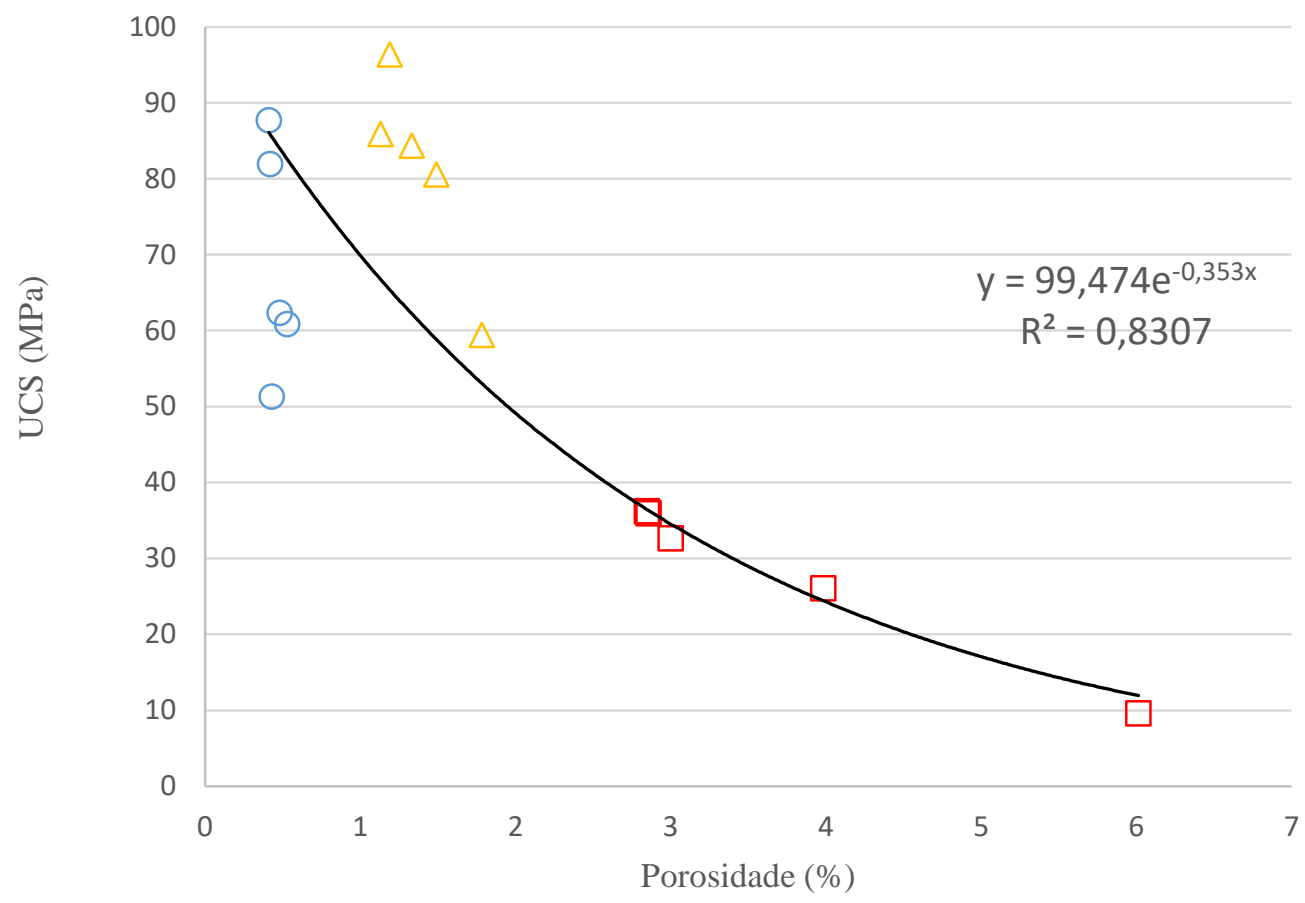

ORocha Sã $\triangle$ Rocha Medianamente Alterada $\quad \square$ Rocha Alterada

Figura 4.19 - Variação da resistência à compressão uniaxial em função da porosidade.

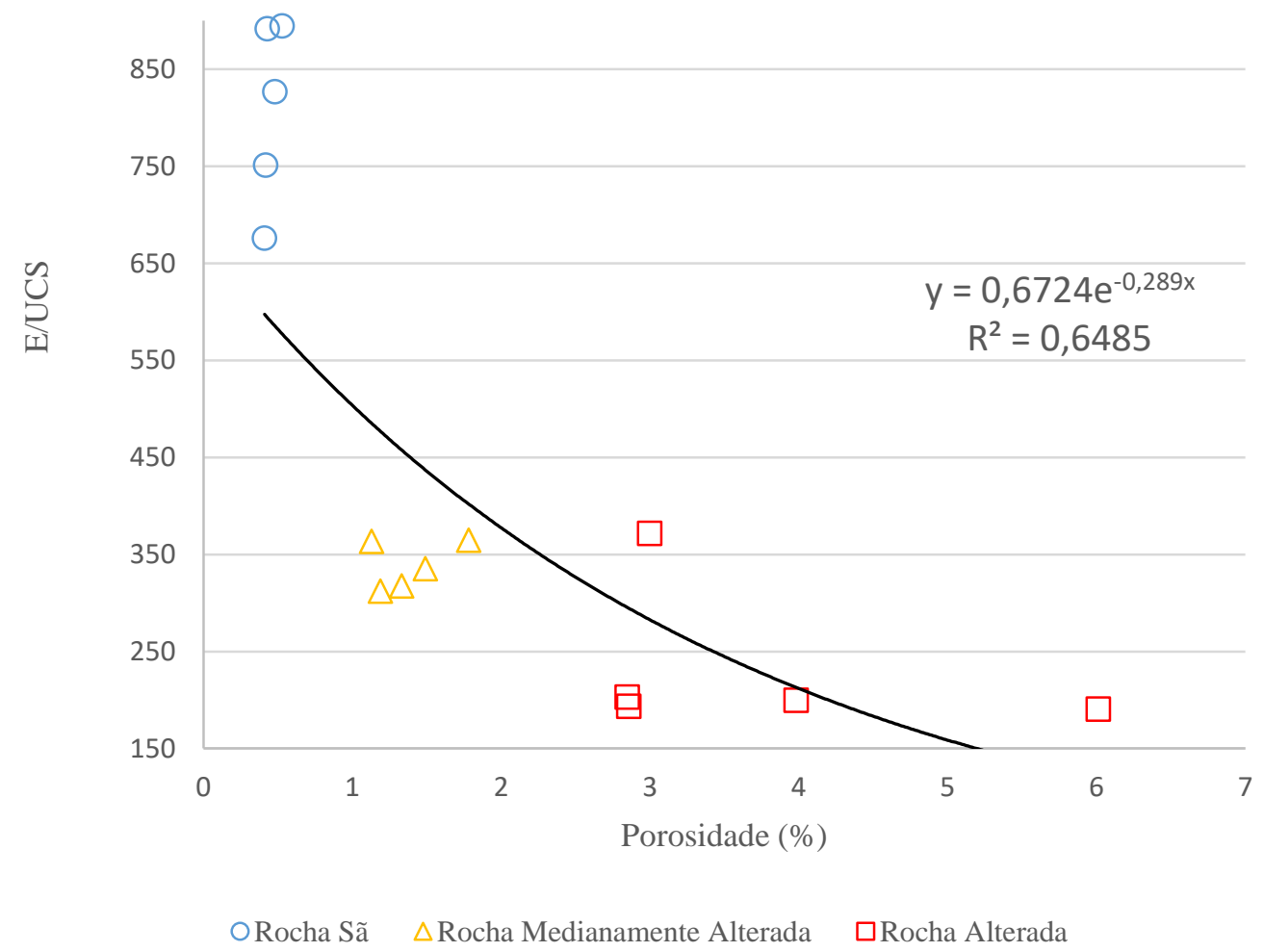

Figura 4.20 - Variação da relação módulo elasticidade/resistência à compressão uniaxial em função da porosidade. 
Tabela 4.7 - Comparação dos resultados de compressão uniaxial obtidos.

\begin{tabular}{ccccc}
\hline \multirow{2}{*}{ Grau de Alteração } & $\begin{array}{c}\text { UCS } \\
(\mathrm{MPa})\end{array}$ & $\begin{array}{c}\text { UCS referente ao } \\
\text { Qmédio }(\mathrm{MPa})\end{array}$ & $\begin{array}{c}\text { UCS referente } \\
\text { ao Ismédio } \\
(\mathrm{MPa})\end{array}$ \\
\hline Rocha Sã & Média & 68,80 & 110,36 & 125,50 \\
Rocha & Média & 81,32 & 31,98 & 29,3 \\
Medianamente & $C V(\%)$ & 16,7 & 25,5 & 56,72 \\
Alterada & Média & 28,08 & 4,33 & 50,3 \\
Rocha Alterada & $C V(\%)$ & 39,6 & 34,9 & 5,42 \\
& & & & 87,3 \\
\hline
\end{tabular}

As correlações apresentadas nas figuras 4.19 e 4.20 são não lineares e apontam para uma diminuição das propriedades geotécnicas analisadas em função do grau de alteração, com exceção das amostras de rochas medianamente alteradas no gráfico da figura 4.19, fato explicado anteriormente.

$\mathrm{Na}$ tabela 4.7, é possível observar os resultados de compressão uniaxial obtidos direta e indiretamente, referentes aos ensaios de esclerometria (Q) e puntiforme $\left(\mathrm{I}_{\mathrm{S}}\right)$. Os valores obtidos, através das correlações feitas com Q e IS, mostraram-se próximos. Analisando os desvios padrão encontrados para os dois, ligeiramente superiores para Q, é possível afirmar que os resultados são semelhantes. No entanto, quando comparados com os resultados obtidos diretamente no ensaio de compressão uniaxial, eles se apresentam muito distantes, não sendo possível encontrar um padrão. Os resultados obtidos para rochas sãs foram superiores enquanto que os resultados obtidos para rochas medianamente alteradas e alteradas foram inferiores. Isso mostra a necessidade do estabelecimento de relações empíricas para as litologias estudadas, a fim de obter valores mais semelhantes aos encontrados no ensaio direto, permitindo assim, o uso destes ensaios mais simples na caracterização mecânica destas rochas.

\section{7}

\section{Ensaio indireto de resistência à tração (ens. Brasileiro)}

Foram realizados 44 (quarenta e quatro) ensaios Brasileiros para determinação da resistência à tração, sendo 19 (dezenove) corpos de prova de rochas sãs, 14 (quatorze) de rochas medianamente alteradas e 11 (onze) de rochas alteradas. Na figura 4.21 são apresentados os resultados em função do grau de alteração. 


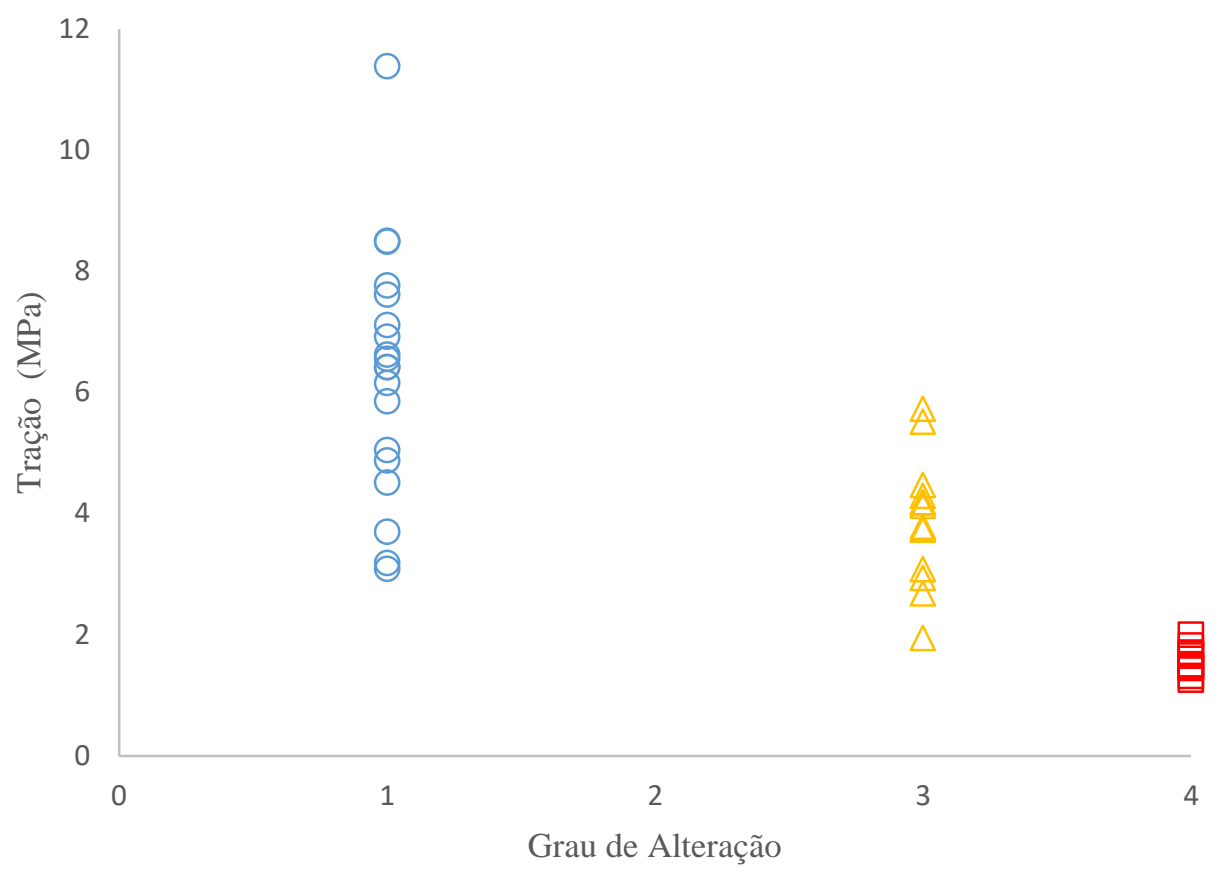

ORocha Sã $\triangle$ Rocha Medianamente Alterada $\square$ Rocha Alterada

Figura 4.21 - Resultados do ensaio Brasileiro em função do grau de alteração das rochas.

Os corpos de prova de rochas medianamente alteradas e alteradas foram extraídos com controle de foliação. Teoricamente, a zero grau temos a menor resistência e a $90^{\circ}$ a maior resistência. Entretanto, nas rochas sãs, tal controle não obteve sucesso devido, por vezes, à dificuldade na identificação dos ângulos tendo em vista as estruturas (migmatíticas, dobras, entre outras) encontradas nas rochas. Tal fato gerou uma maior dispersão das rochas sãs.

A tabela 4.8 apresenta um resumo dos resultados obtidos nos ensaios. A figura 4.22 apresenta a variação das resistências à tração obtidas nos ensaios brasileiros em função da direção da foliação dos corpos de prova ensaiados. Já a figura 4.23 apresenta a variação das resistências à tração com as porosidades dos corpos de prova.

Tabela 4.8 - Resumo dos resultados obtidos no ensaio Brasileiro.

\begin{tabular}{cccc}
\hline Grau de Alteração & & $\sigma_{t}(\mathrm{MPa})$ & $\mathrm{UCS} / \sigma_{t}$ \\
\hline \multirow{2}{*}{ Rocha Sã } & Média & 6,33 & \multirow{2}{*}{10,87} \\
& $C V(\%)$ & 32,1 & \\
Rocha Medianamente & Média & 3,88 & \multirow{2}{*}{20,94} \\
Alterada & $C V(\%)$ & 26,4 & \\
Rocha Alterada & Média & 1,58 & \multirow{2}{*}{17,80} \\
\hline
\end{tabular}




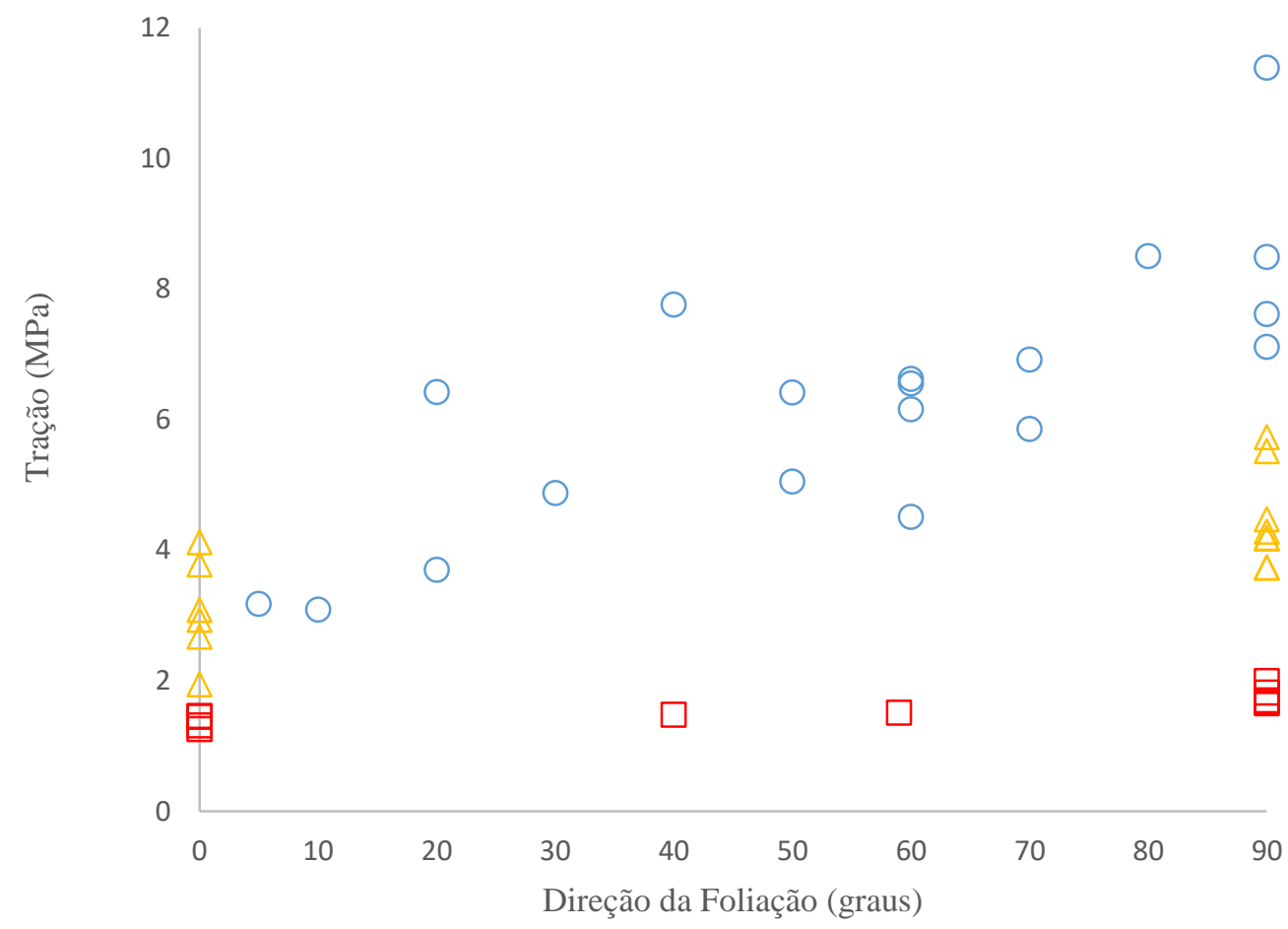

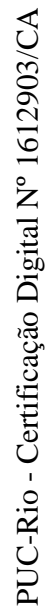

ORocha Sã $\triangle$ Rocha Medianamente Alterada $\square$ Rocha Alterada

Figura 4.22 - Variação da resistência à tração obtida no ensaio Brasileiro em função da direção da foliação.

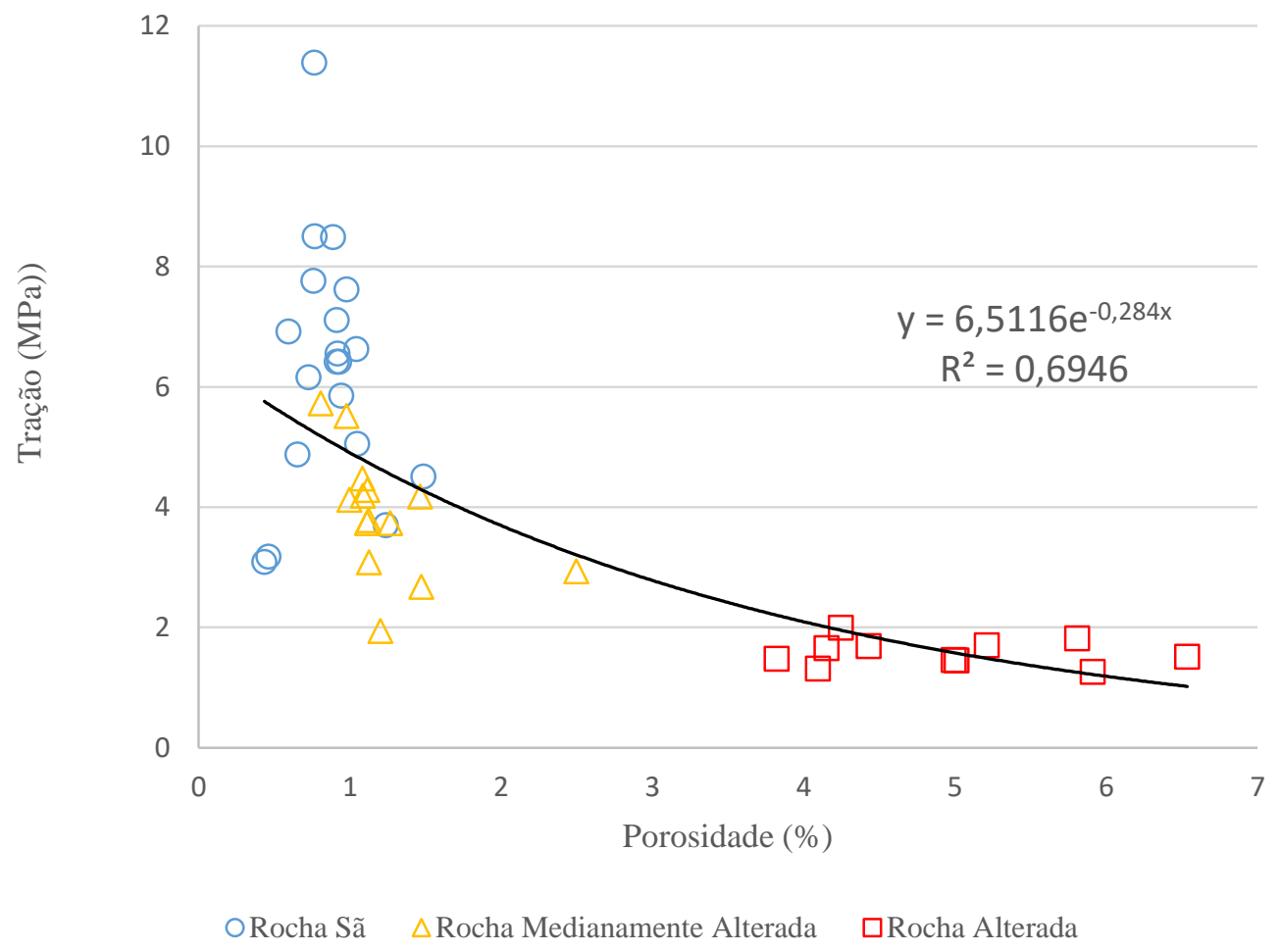

Figura 4.23 - Variação da resistência à tração obtida no ensaio Brasileiro em função da porosidade. 
Na tabela 4.8, a redução das resistências à tração obtidas nos ensaios, tomando a rocha sã como base, foi de $38,7 \%$ para a medianamente alterada e de $75,0 \%$ para a rocha alterada. No gráfico da figura 4.22 também é possível observar que as rochas sãs apresentam uma maior diferença entre os valores máximos e mínimos. Enquanto nas rochas medianamente alteradas essa diferença é bem menor, nas rochas alteradas é praticamente inexistente.

A variação da resistência à tração em função da porosidade é uma correlação não linear. No gráfico da figura 4.23, também foi possível observar que os corpos de provas de rochas medianamente alteradas apresentaram porosidades mais próximas das rochas sãs, porém os valores de resistência à tração se mantiveram mais baixos, como esperado.

\section{8}

\section{Ensaio de tenacidade à fratura CCNDB}

Foram realizados 31 (trinta e um) ensaios para a determinação da tenacidade à fratura utilizando corpo de prova em forma de disco brasileiro com entalhe em V ou "chevron". Desses, 19 (dezenove) foram realizados em rochas sãs, 8 (oito) em rochas medianamente alteradas e 4 (quatro) em rochas alteradas.

Em função do pequeno número de corpos de prova de rochas mais alteradas, oriundo das limitações advindas dos processos de amostragem, a grande maioria dos ensaios foi realizada preferencialmente na menor resistência, estando a foliação paralela à força aplicada $\left(0^{\circ}\right)$. Para as rochas sãs, em função da maior quantidade de corpos de prova, foi possível realizar um melhor controle. Assim sendo, foram ensaiados corpos de prova com entalhe paralelo $\left(0^{\circ}\right)$, ortogonal $\left(90^{\circ}\right)$ e inclinado à foliação $\left(45^{\circ}\right)$.

Apesar da baixa quantidade de amostras de rochas alteradas, foi realizado um ensaio na direção ortogonal à foliação $\left(90^{\circ}\right)$, de maior resistência, com o objetivo de comparar o resultado da tenacidade à fratura, mesmo que minimamente, com a direção de menor de resistência, paralela à foliação $\left(0^{\circ}\right)$.

A tabela 4.9 apresenta a quantidade de ensaios realizados nas respectivas direções. E a figura 4.24 mostra um corpo de prova de cada grau de alteração nas suas respectivas direções a ser ensaiadas. 
Tabela 4.9 - Ensaios CCNDB realizados.

\begin{tabular}{ccc}
\hline Grau de Alteração & $\begin{array}{c}\text { Direção do } \\
\text { Ensaio }\end{array}$ & $\begin{array}{c}\text { Quantidade de } \\
\text { Ensaios } \\
\text { Realizados }\end{array}$ \\
\hline Rocha Sã & $0^{\circ}$ & 7 \\
$45^{\circ}$ & 5 \\
Rocha & $90^{\circ}$ & 7 \\
Medianamente & $0^{\circ}$ & 5 \\
Alterada & $90^{\circ}$ & 3 \\
Rocha Alterada & $0^{\circ}$ & 3 \\
& $90^{\circ}$ & 1 \\
\hline
\end{tabular}

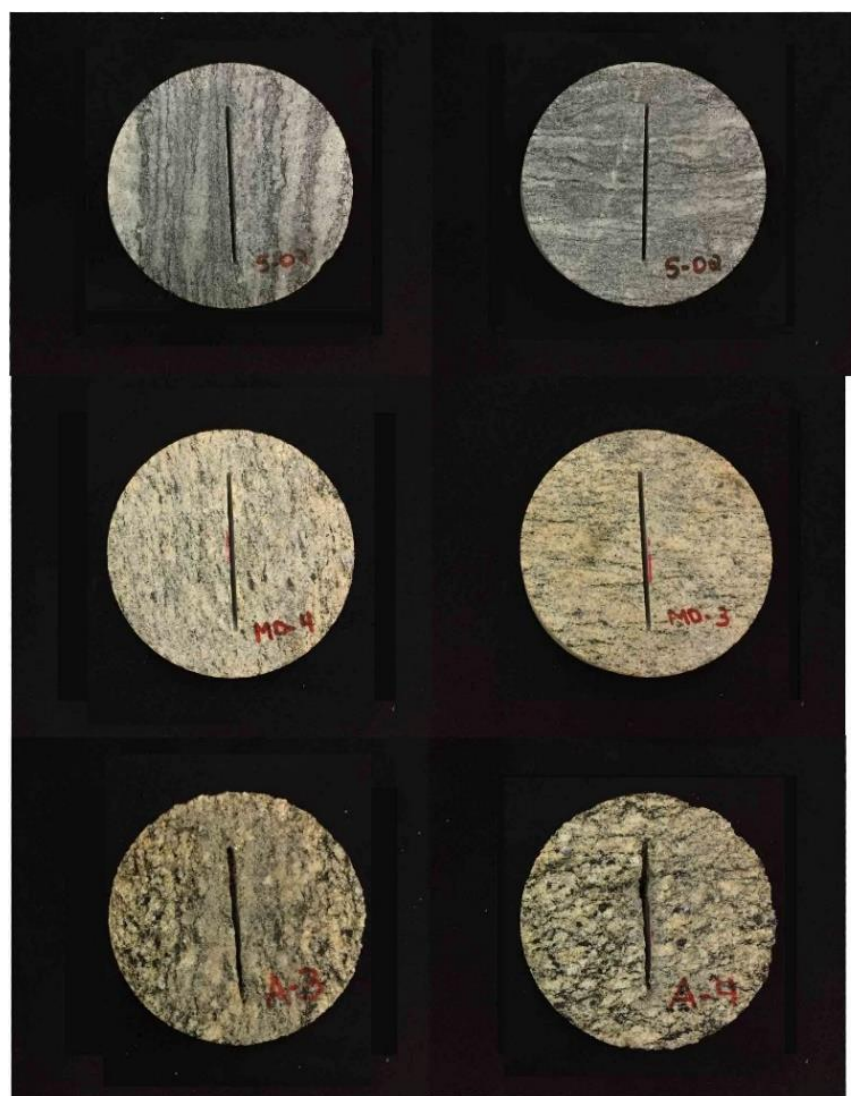

Figura 4.24 - Corpos de prova utilizados no ensaio CCNDB nos seus respectivos graus de alteração e direção do entalhe.

Como mencionado no item 3.2.8 do capítulo 3 do presente trabalho, para que os testes sejam validos é necessário que os corpos de prova satisfaçam 6 (seis) condições descritas nas equações 3.28 a 3.33 (ISRM, 1995). O gráfico da figura 4.25 mostra os limites gerados pelas equações mencionadas e são plotados dois dos três parâmetros geométricos básicos do CCNDB $\left(\alpha_{1}\right.$ e $\left.\alpha_{B}\right)$ de cada corpo de prova. Dessa maneira, foi possível identificar que todos os corpos de prova tinham geometrias válidas. 


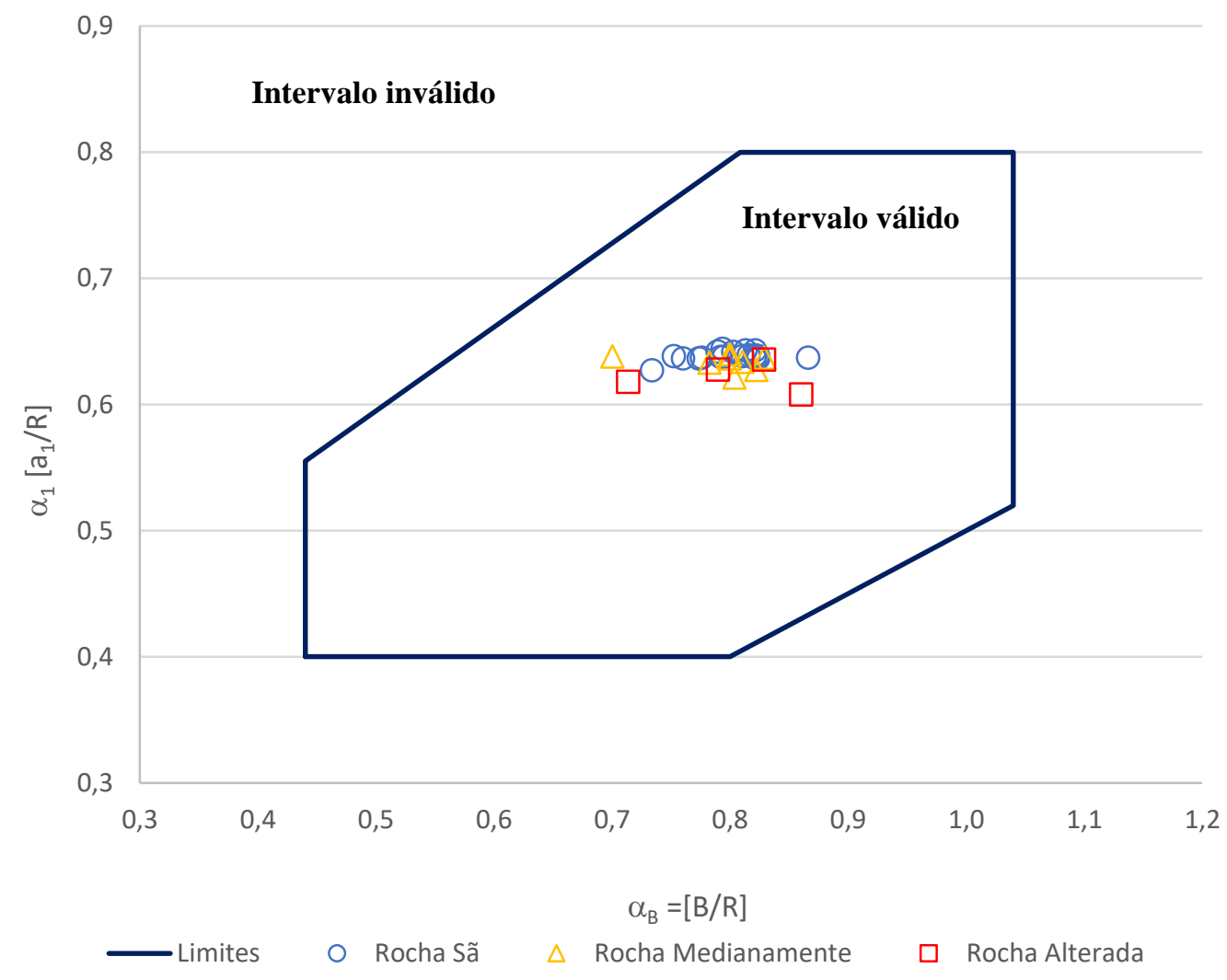

Figura 4.25 - Escopo da geometria válida para corpos de prova CCNDB.

$\mathrm{Na}$ figura 4.26 os resultados obtidos são apresentados em função do grau de alteração. A tabela 4.10 apresenta um resumo dos ensaios realizados.

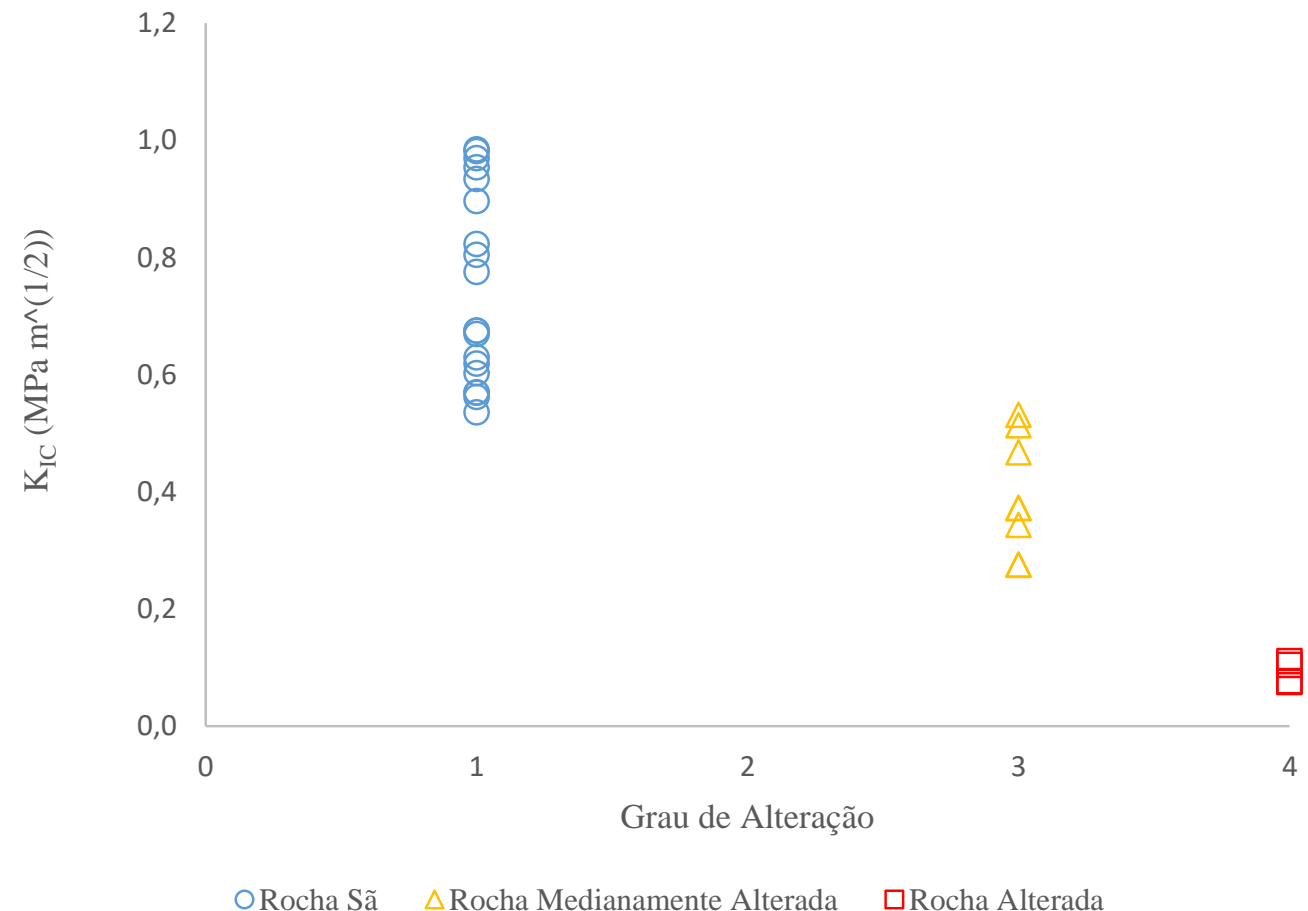

Figura 4.26 - Resultado do ensaio CCNDB em função do grau de alteração. 
Tabela 4.10 - Resumo dos resultados obtidos no ensaio CCNDB.

\begin{tabular}{|c|c|c|c|c|c|c|}
\hline $\begin{array}{l}\text { Corpo de } \\
\text { Prova }\end{array}$ & $\begin{array}{c}\text { Direção } \\
\text { do } \\
\text { Entalhe }\end{array}$ & $\mathrm{u}$ & $\mathrm{v}$ & $Y_{\min }$ & $\begin{array}{l}\mathrm{P}_{\text {máx }} \\
\mathrm{kN}\end{array}$ & $\begin{array}{c}\mathrm{K}_{\mathrm{IC}} \\
\mathrm{MPa} \mathrm{m}^{\wedge}(1 / 2)\end{array}$ \\
\hline S-06 T & $0^{\circ}$ & 0,269 & 1,763 & 0,826 & 5,22 & 0,536 \\
\hline $\mathrm{S}-07 \mathrm{~T}$ & $0^{\circ}$ & 0,265 & 1,755 & 0,817 & 6,88 & 0,676 \\
\hline S-08 T & $0^{\circ}$ & 0,271 & 1,770 & 0,840 & 6,27 & 0,675 \\
\hline S-10 T & $0^{\circ}$ & 0,266 & 1,763 & 0,818 & 5,52 & 0,562 \\
\hline S-11 T & $0^{\circ}$ & 0,268 & 1,761 & 0,822 & 7,90 & 0,823 \\
\hline S-14 T & $0^{\circ}$ & 0,264 & 1,757 & 0,808 & 6,00 & 0,569 \\
\hline S-16 T & $0^{\circ}$ & 0,264 & 1,757 & 0,810 & 6,65 & 0,630 \\
\hline S-09 T & $45^{\circ}$ & 0,263 & 1,755 & 0,803 & 6,59 & 0,619 \\
\hline S-12 T & $45^{\circ}$ & 0,268 & 1,765 & 0,826 & 5,69 & 0,570 \\
\hline S-13 T & $45^{\circ}$ & 0,264 & 1,757 & 0,819 & 6,97 & 0,670 \\
\hline S-15 T & $45^{\circ}$ & 0,266 & 1,757 & 0,817 & 6,21 & 0,603 \\
\hline S-19 T & $45^{\circ}$ & 0,267 & 1,755 & 0,802 & 7,64 & 0,805 \\
\hline S-01 T & $90^{\circ}$ & 0,270 & 1,764 & 0,831 & 9,44 & 0,954 \\
\hline S-02 T & $90^{\circ}$ & 0,273 & 1,764 & 0,848 & 9,02 & 0,934 \\
\hline S-03 T & $90^{\circ}$ & 0,266 & 1,757 & 0,825 & 7,93 & 0,775 \\
\hline S-04 T & $90^{\circ}$ & 0,268 & 1,765 & 0,834 & 9,73 & 0,985 \\
\hline $\mathrm{S}-05 \mathrm{~T}$ & $90^{\circ}$ & 0,266 & 1,758 & 0,819 & 9,33 & 0,896 \\
\hline S-17 T & $90^{\circ}$ & 0,262 & 1,752 & 0,801 & 11,02 & 0,982 \\
\hline $\mathrm{S}-20 \mathrm{~T}$ & $90^{\circ}$ & 0,267 & 1,758 & 0,822 & 9,99 & 0,970 \\
\hline MD-04 T & $0^{\circ}$ & 0,266 & 1,755 & 0,813 & 5,24 & 0,514 \\
\hline MD-05 T & $0^{\circ}$ & 0,269 & 1,763 & 0,823 & 2,71 & 0,275 \\
\hline MD-07 T & $0^{\circ}$ & 0,262 & 1,754 & 0,786 & 4,03 & 0,372 \\
\hline MD-08 T & $0^{\circ}$ & 0,266 & 1,755 & 0,819 & 3,49 & 0,344 \\
\hline MD-10 T & $0^{\circ}$ & 0,282 & 1,770 & 0,871 & 3,11 & 0,373 \\
\hline MD-01 T & $90^{\circ}$ & 0,261 & 1,752 & 0,776 & 5,70 & 0,531 \\
\hline MD-03 T & $90^{\circ}$ & 0,266 & 1,759 & 0,815 & 4,93 & 0,467 \\
\hline MD-06 T & $90^{\circ}$ & 0,263 & 1,756 & 0,801 & 2,90 & 0,277 \\
\hline A-01 T & 0 & 0,273 & 1,764 & 0,827 & 0,75 & 0,077 \\
\hline A-02 T & $0^{\circ}$ & 0,264 & 1,752 & 0,767 & 0,85 & 0,076 \\
\hline A-03 T & $0^{\circ}$ & 0,265 & 1,758 & 0,809 & 1,11 & 0,105 \\
\hline A-04 T & $90^{\circ}$ & 0,276 & 1,775 & 0,825 & 0,99 & 0,111 \\
\hline
\end{tabular}

A tabela 4.11 apresenta as médias das tenacidades à fratura obtidas nos ensaios CCNDB. 
Tabela 4.11 - Média dos resultados obtidos no ensaio CCNDB.

\begin{tabular}{cccc}
\hline \multirow{3}{*}{ Grau de Alteração } & $\begin{array}{c}\text { Direção } \\
\text { do } \\
\text { Ensaio }\end{array}$ & KICmédio & $C V(\%)$ \\
\hline \multirow{2}{*}{ Rocha Sã } & $0^{\circ}$ & 0,639 & 15,4 \\
& $45^{\circ}$ & 0,653 & 14,1 \\
Rocha & $90^{\circ}$ & 0,928 & 8,0 \\
Medianamente & $0^{\circ}$ & 0,376 & 23,1 \\
Alterada & $90^{\circ}$ & 0,425 & 31,2 \\
Rocha Alterada & $0^{\circ}$ & 0,086 & 19,2 \\
& $90^{\circ}$ & 0,111 & - \\
\hline
\end{tabular}

Os resultados obtidos apresentaram dois padrões principais. Primeiramente houve uma diminuição da tenacidade à fratura à medida que o grau de alteração aumentava. E, em relação à direção do entalhe com a foliação, os três graus de alteração apresentaram as características esperadas. $\mathrm{Na}$ direção paralela $\left(0^{\circ}\right)$, foi obtida a menor resistência; na direção ortogonal $\left(90^{\circ}\right)$, foi obtida a maior resistência; e, nas rochas sãs, onde foram realizados ensaios à $45^{\circ}$, os valores obtidos foram intermediários ao máximo e ao mínimo.

Em relação às rochas sãs, as rochas medianamente alteradas apresentaram uma redução da tenacidade à fratura de $41,2 \%$ com o entalhe paralelo à foliação e $54,2 \%$ com o entalhe ortogonal à foliação. Já as rochas alteradas apresentaram $86,6 \%$ e $88,0 \%$ com os entalhes paralelo e ortogonal à foliação, respectivamente.

Quando comparadas as direções onde são obtidas as tenacidades à fratura máximas (entalhe ortogonal) e mínimas (entalhe paralelo) para cada grau de alteração e, incluindo no caso das rochas sãs, a direção intermediária, as diminuições foram: 22,9\% para rochas alteradas, 11,6\% para as rochas medianamente alteradas, $31,2 \%$ para rochas sãs com entalhe paralelo à foliação e $29,6 \%$ para rochas sãs com entalhe inclinado $\left(45^{\circ}\right)$ à foliação.

Esses resultados mostram que a diferença entre as tenacidades à fratura obtidas para rochas sãs com entalhe paralelo e com entalhe inclinado foram pequenas. Outro fato observado é que não houve um padrão quanto à redução das tenacidades entre os valores mínimos (paralelo) e máximos (ortogonal).

A seguir, são apresentadas correlações da tenacidade à fratura com a foliação (figura 4.27), com a porosidade (figura 4.28), com a resistência à compressão uniaxial (figura 4.29) e com a resistência à tração (figura 4.30). 


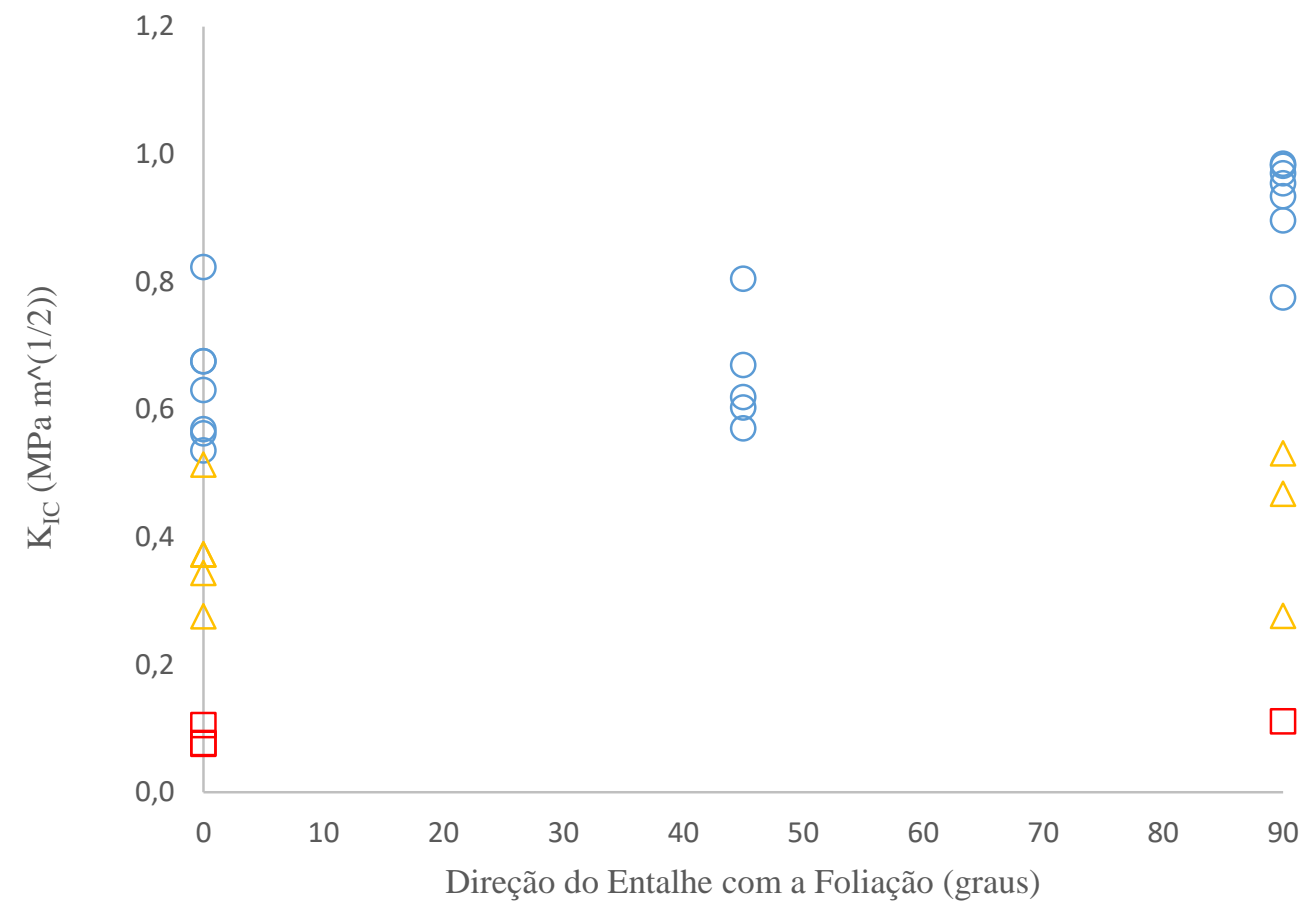

ORocha Sã $\triangle$ Rocha Medianamente Alterada $\quad \square$ Rocha Alterada

Figura 4.27 - Variação da tenacidade à fratura obtida no ensaio CCNDB em função da direção do entalhe com a foliação.

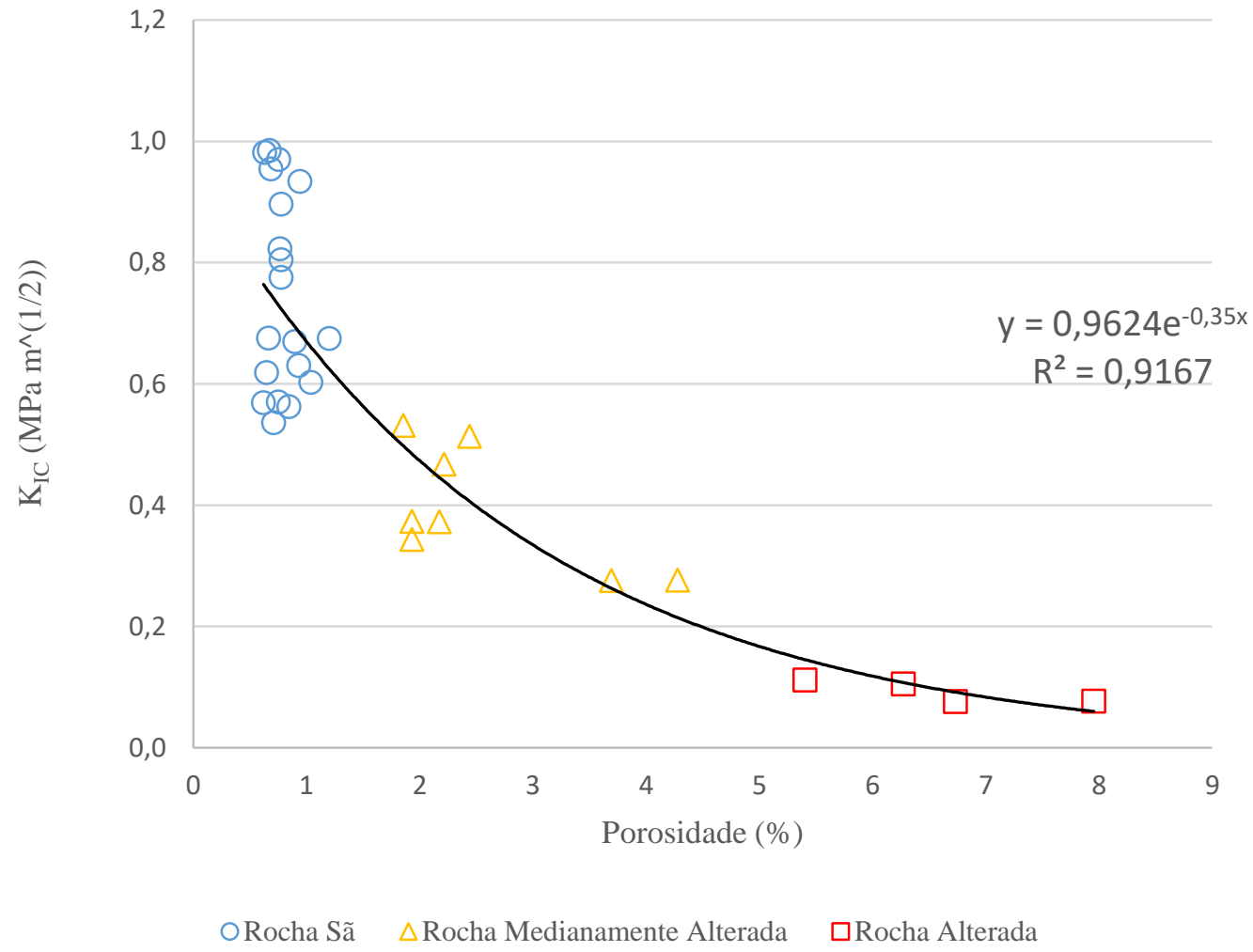

Figura 4.28 - Variação da tenacidade à fratura obtida no ensaio CCNDB em função da porosidade. 


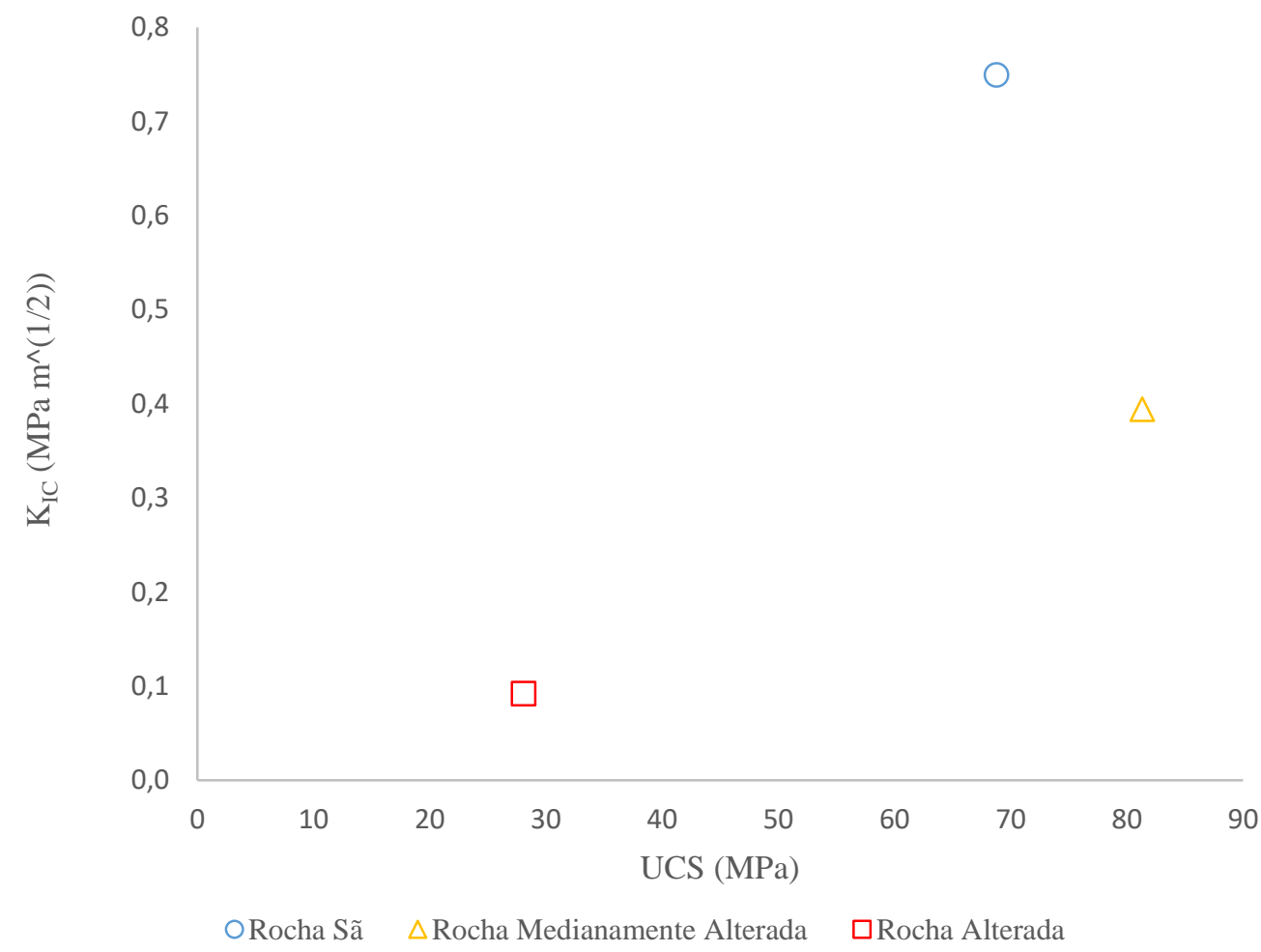

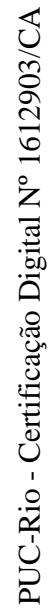

Figura 4.29 - Variação dos resultados médios da tenacidade à fratura (CCNDB) em função dos resultados médios de resistência à compressão uniaxial.

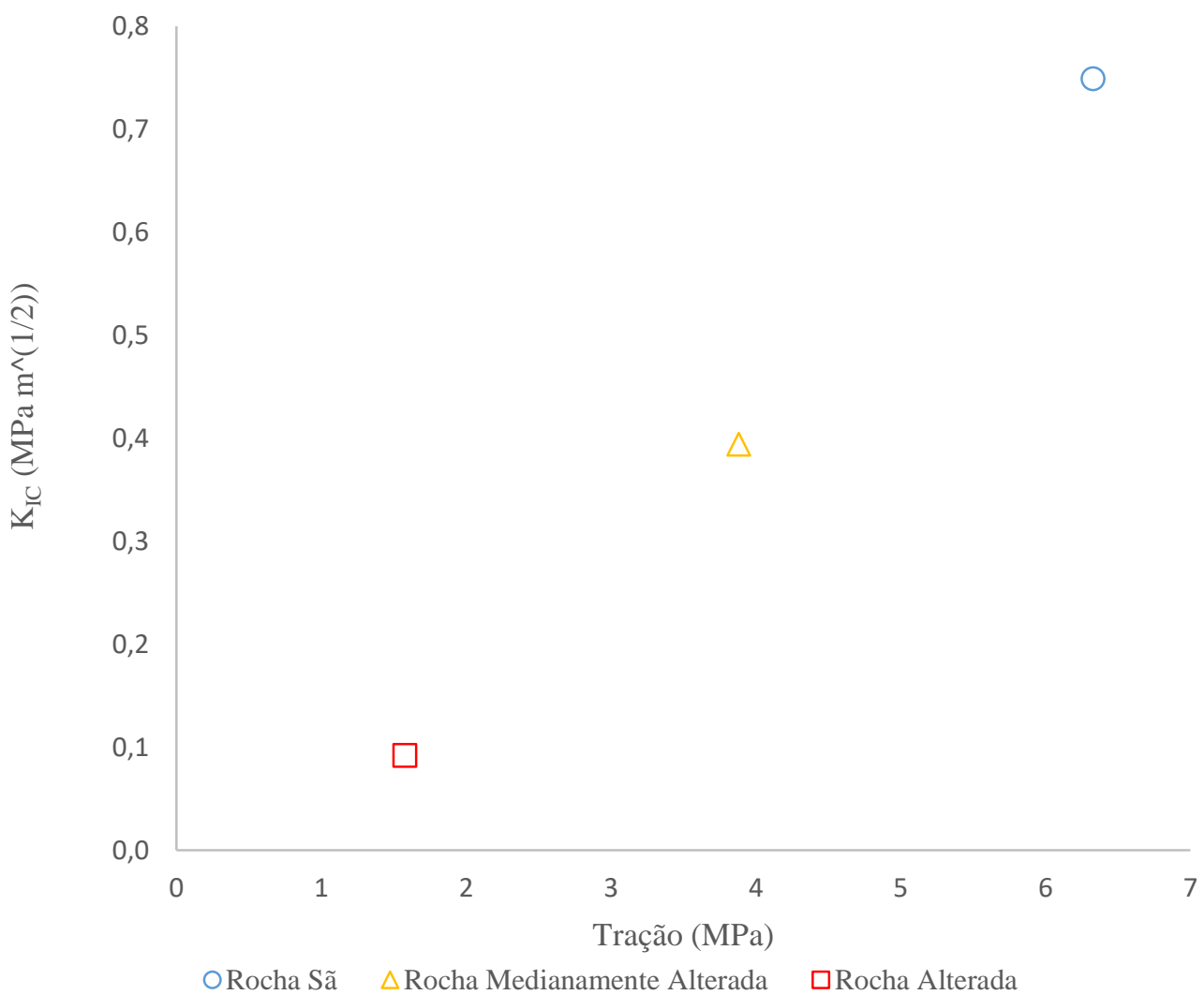

Figura 4.30 - Variação dos resultados médios da tenacidade à fratura (CCNDB) em função dos resultados médios de resistência à tração (ensaio Brasileiro). 
A tenacidade à fratura apresenta uma correlação não linear com a porosidade, representada na figura 4.28.

Assim como nos resultados de resistência à tração indireta (ensaio brasileiro), foi possível observar uma maior diferença entre os valores máximos e mínimos das rochas sãs. Nas rochas medianamente alteradas, essa diferença é menor, enquanto nas rochas alteradas não existe diferença.

O gráfico da figura 4.29 corrobora o fato de as rochas medianamente alteradas, apesar de apresentarem resultados de resistência à compressão uniaxial maiores que a rocha sã, possuírem resultados da tenacidade inferiores. Já os resultados da resistência à tração obtidos nos ensaios brasileiros (figura 4.30) apresentam uma correlação linear com os resultados da tenacidade à fratura, mostrando que ambas diminuem com o aumento do grau de alteração.

A figura 4.31 apresenta um gráfico onde são plotados os valores médios dos resultados da tenacidade à fratura (ensaio CCNDB) e da resistência à tração (ensaio Brasileiro) em função das respectivas porosidades.

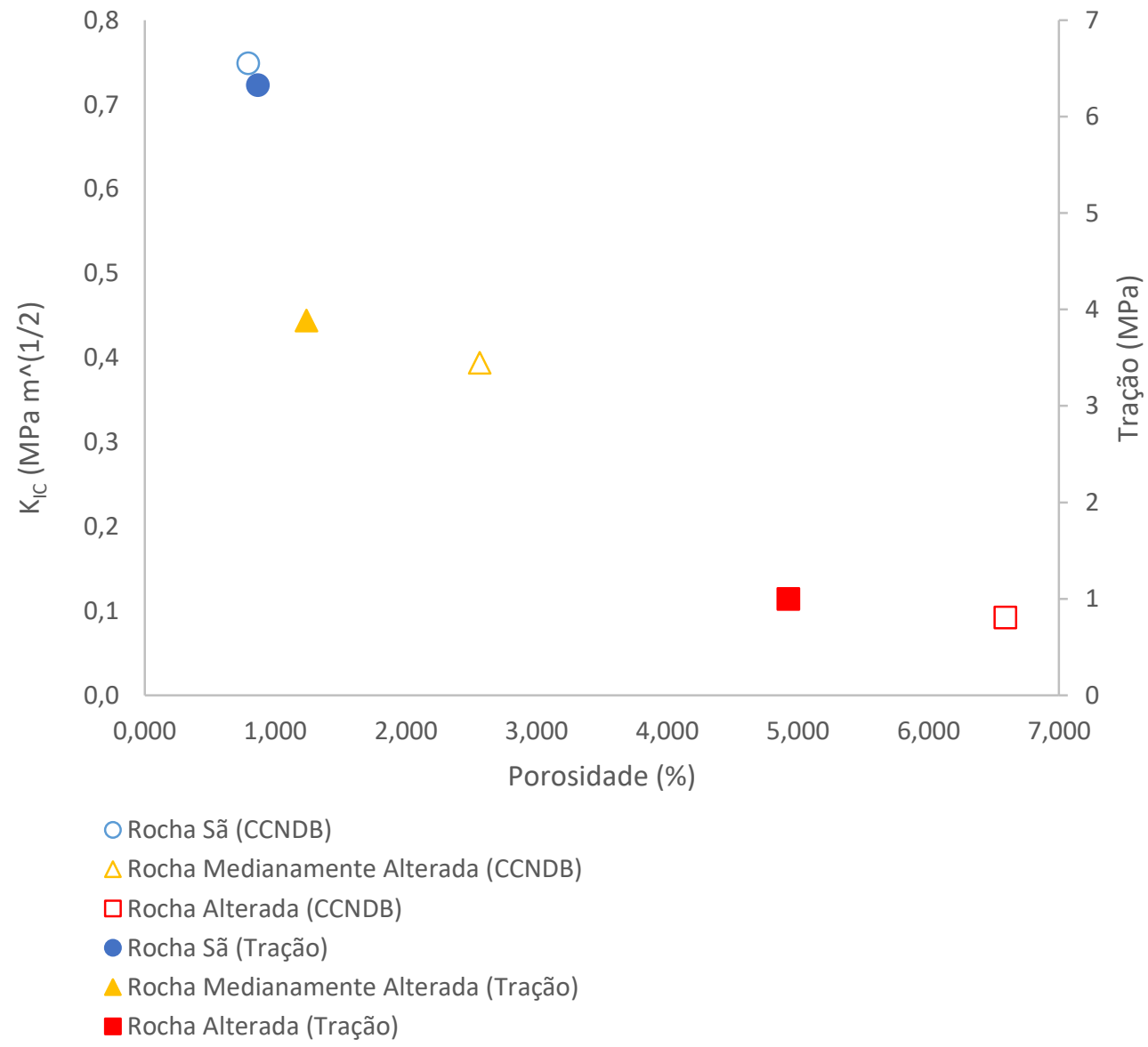

Figura 4.31- Variação dos resultados médios da tenacidade à fratura (CCNDB) e dos resultados médios de resistência à tração (ensaio Brasileiro) em função das respectivas porosidades. 
No gráfico da figura 4.31, é possível verificar que os resultados da tenacidade à fratura (ensaio CCNDB) e da resistência à tração (ensaio Brasileiro) apresentam comportamento semelhante, porém os corpos de prova do Ensaio Brasileiro apresentaram porosidade média, para as rochas medianamente alteradas e alteradas, menor que os corpos de prova dos ensaios CCNDB.

No gráfico força-deslocamento, da figura 4.32, são apresentadas as curvas típicas representativas das rochas ensaiadas. Foram utilizadas as curvas dos corpos de prova: S-08 T, S-20 T, MD-07 T, MD-02 T e A-02 T.

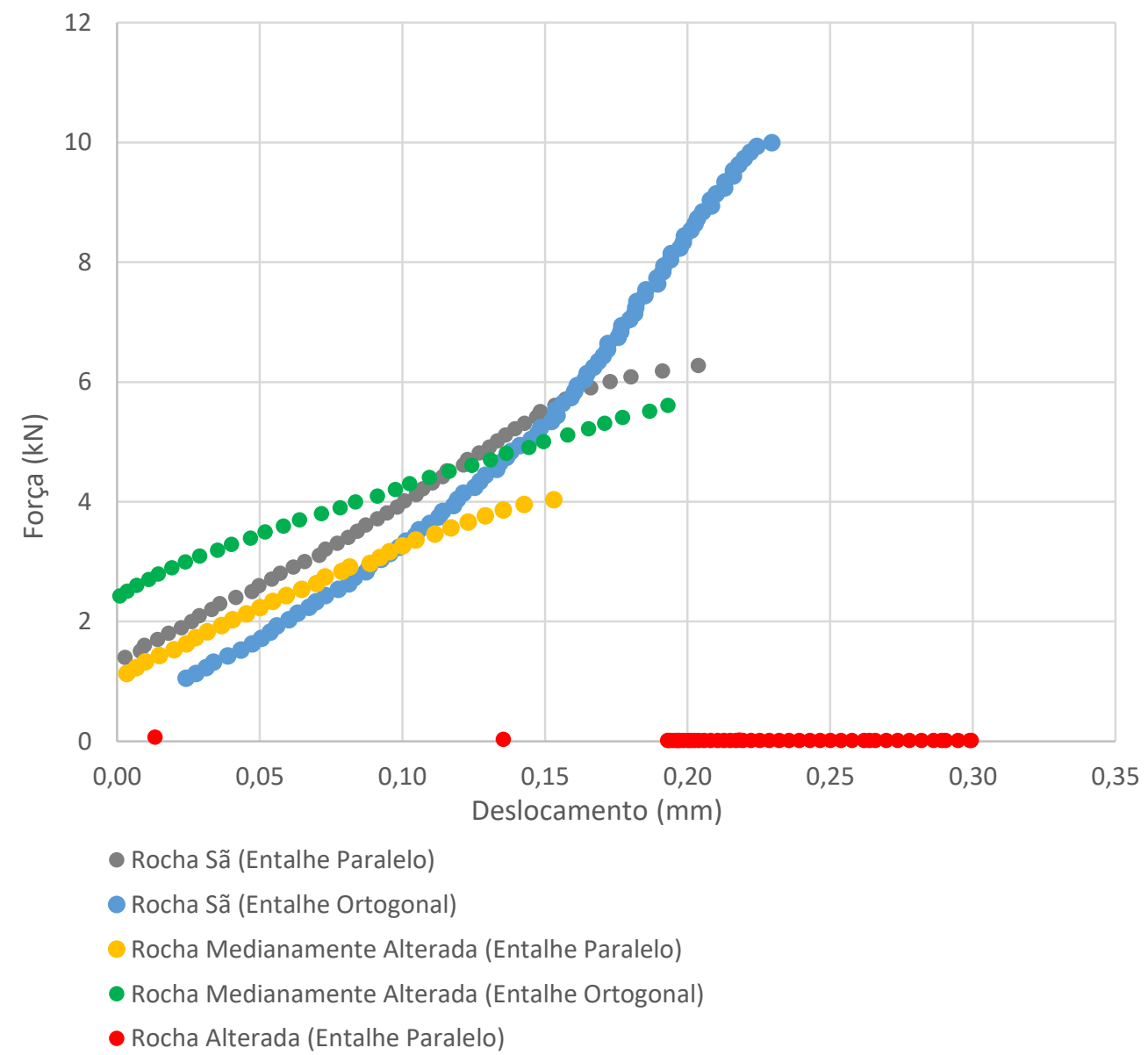

Figura 4.32 - Curvas força-deslocamento típicas dos litotipos estudados.

Em virtude da baixa tenacidade à fratura das rochas alteradas, a força aplicada durante o ensaio foi muito baixa, impossibilitando, assim, uma melhor visualização da curva quando comparada com as curvas dos outros graus de alteração, em função da escala.

Como citado anteriormente, Santos (2004) realizou ensaios CCNDB para determinar a tenacidade à fratura de gnaisses facoidais na cidade do Rio de 
Janeiro. Por se tratar de litotipos semelhantes, a comparação dos resultados obtidos é válida (tabela 4.12).

Tabela 4.12 - Resultados médios dos ensaios CCNDB obtidos no presente trabalho e em Santos (2004).

\begin{tabular}{cccc}
\hline Grau de Alteração & $\begin{array}{c}\text { Direção do } \\
\text { Ensaio }\end{array}$ & K ICmédio & $\begin{array}{c}\text { Santos (2004) } \\
\text { K ICmédio }\end{array}$ \\
\hline \multirow{2}{*}{ Rocha Sã } & $0^{\circ}$ & 0,639 & 0,670 \\
& $45^{\circ}$ & 0,653 & - \\
Rocha Levemente & $90^{\circ}$ & 0,928 & 0,990 \\
Alterada & $0^{\circ}$ & - & - \\
Rocha Medianamente & $45^{\circ}$ & - & 0,240 \\
Alterada & $90^{\circ}$ & - & 0,580 \\
& $0^{\circ}$ & 0,376 & - \\
Rocha Alterada & $45^{\circ}$ & - & 0,250 \\
& $90^{\circ}$ & 0,425 & 0,420 \\
& $0^{\circ}$ & 0,086 & - \\
\hline
\end{tabular}

$\mathrm{Na}$ tabela 4.12, é possível verificar que, apesar de alguns ensaios terem sidos realizados em direções distintas (em rochas sãs $0^{\circ}$ e $90^{\circ}$ e em rochas medianamente alteradas $90^{\circ}$ ), os resultados médios obtidos no presente trabalho foram muito semelhantes aos resultados encontrados por Santos (2004).

Como mencionado no capítulo anterior, foram realizados dois ensaios com extensômetro do tipo clip gauge como teste. O clip gauge foi instalado nos corpos de prova S-04 T (com entalhe ortogonal à foliação) e S-16 T (com entalhe paralelo à foliação). Na figura 4.31, são apresentados os resultados juntamente com as curvas dos dois ensaios em rochas sãs citados na figura 4.32.

Os ensaios com clip gauge inicialmente foram realizados iguais a todos os outros, após o rompimento o extensômetro controla o ensaio através da abertura da trinca. Nas curvas, é possível analisar o comportamento do material após a ruptura. As desvantagens são: os corpos de prova necessitam de uma preparação mais elaborada para a instalação dos clips gauges; e os ensaios são mais demorados, pois duraram cerca de 10 minuntos. 


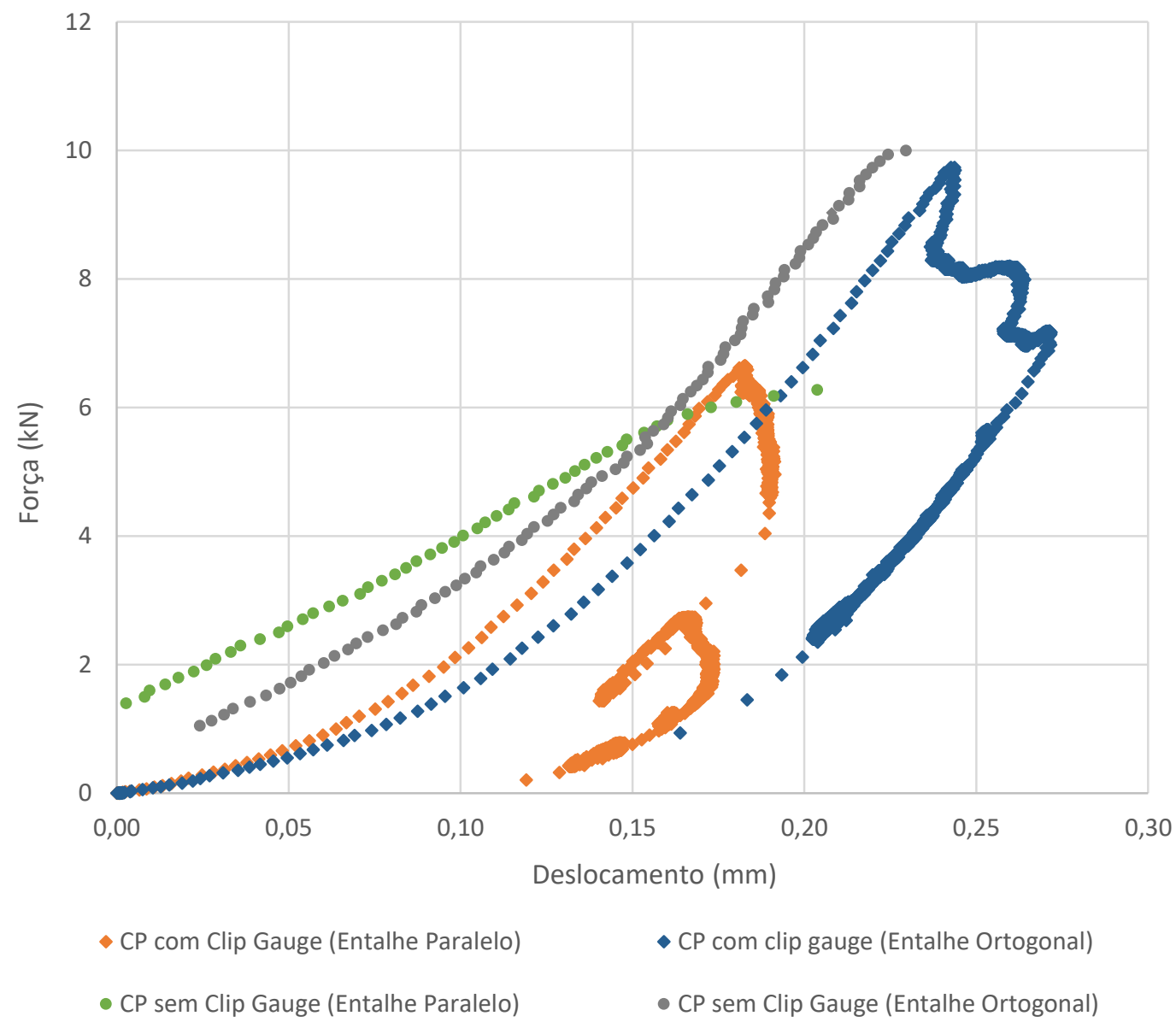

Figura 4.33 - Curvas força-deslocamento dos corpos com clip gauge.

Foram plotadas no gráfico (figura 4.32) as curvas dos ensaios realizados sem clip gauge para que as curvas fossem comparadas até a ruptura. E os resultados obtidos foram bastante satisfatórios, principalmente nos corpos de prova com entalhe ortogonal. 


\section{5 \\ Conclusões e sugestões para futuros trabalhos}

\section{1 \\ Conclusões}

As análises petrográficas e mineralógicas por difração de raio $\mathrm{X}(\mathrm{DRX})$ confirmaram os graus de alterações das rochas estudadas, previamente analisadas por descrição táctil visual. Foi possível observar uma pequena diferença na granulometria e na composição mineralógica entre a rocha sã e as demais. A rocha sã apresenta uma composição granodiorítica com granulometria fina, enquanto as rochas medianamente alterada e alterada têm composição quartzo-diorítica com granulometria fina a média. As rochas medianamente alteradas também não apresentaram um bandamento gnáissico bem marcado.

Os difratogramas apresentaram picos típicos das mineralogias identificadas na análise das lâminas petrográficas. A rocha medianamente alterada e, principalmente, a rocha alterada apresentaram picos de argilominerais (vermiculita, montimorilonita e clorita). Tais picos podem ser fruto da alteração sofrida pelas rochas, porém apenas através do método do pó não é possível obter tal resposta, sendo necessária a realização de outras técnicas para identificação desses argilominerais.

Eventualmente os parâmetros adotados na Sugestão para Classificação e Descrição de Maciços Rochosos da ISRM (ISRM, 2007 apud Marques, 2010) não funcionam para qualquer tipo de rocha. Por exemplo, em rochas de granulometria muito fina ou rochas com textura afanítica, onde não é possível identificar os minerais.

$\mathrm{Na}$ caracterização dos índices físicos, foram analisados peso específico seco e porosidade, parâmetros que têm uma relação linear. Foi constatado o aumento da porosidade conforme a intensificação do grau de alteração. Os valores médios da porosidade apresentaram um aumento, em relação às rochas sãs, de 121,5\% para as rochas medianamente alteradas e de $584,8 \%$ para as rochas alteradas. Já o peso específico seco diminui à medida que o grau de alteração aumenta. A 
redução foi de 1,9\% nas rochas medianamente alteradas e de 3,7\% nas rochas alteradas.

Os resultados obtidos na caracterização dos índices físicos se mostraram semelhantes aos resultados encontrados em Menezes Filho (1993) e Santos (2004), os quais foram realizados em gnaisses facoidais localizados na cidade do Rio de Janeiro. Os gnaisses facoidais são rochas semelhantes às estudadas no presente trabalho. Nos dois casos, trata-se de rochas gnáissicas ortoderivadas de composição mineralógica similar.

Nos ensaios esclerométricos e de point load, as resistências obtidas diminuíram à medida que o grau de alteração aumentou. A redução da resistência no ensaio de point load axial foi de $52,7 \%$ para rochas medianamente alteradas e de $95,6 \%$ para rochas alteradas.

No ensaio de compressão uniaxial, as rochas medianamente alteradas apresentaram maior deformação e módulos de elasticidade inferiores às rochas sãs, porém as resistências geraram valores próximos e alguns superiores. Um fato observado, que pode ter influenciado, foi a diferença na composição mineralógica, granulométrica e estrutural entre as rochas, associado ao efeito escala, uma vez que os corpos de prova têm aproximadamente $135 \mathrm{~mm}$.

A redução das resistências à tração obtidas nos ensaios brasileiros, tomando a rocha sã como base, foi de $38,7 \%$ para a medianamente alterada e de $75,0 \%$ para a rocha alterada.

Nos ensaios de tenacidade à fratura CCNDB foram identificados dois padrões: a diminuição da tenacidade com o aumento do grau de alteração e a diferença da tenacidade em relação à direção do entalhe com a foliação. A menor tenacidade foi obtida na direção paralela $\left(0^{\circ}\right)$, a maior foi obtida na direção ortogonal $\left(90^{\circ}\right)$ e valores intermediários na direção inclinada $\left(45^{\circ}\right)$.

As reduções das tenacidades à fratura para as rochas medianamente alteradas foram de $41,2 \%$ para o entalhe paralelo e $54,2 \%$ para o entalhe ortogonal. Nas rochas alteradas foram de $86,6 \%$ para o entalhe paralelo e $88,0 \%$ para o entalhe ortogonal.

Em relação às direções do entalhe com a foliação (ortogonal - máxima e paralelo - mínima), a redução foi de 22,9\% para rochas alteradas, 11,6\% para as rochas medianamente alteradas, 31,2\% para rochas sãs com entalhe paralelo à foliação e 29,6\% para rochas sãs com entalhe inclinado $\left(45^{\circ}\right)$ à foliação. 
Os resultados obtidos da tenacidade à fratura para rochas gnáissicas estudadas se mostraram semelhantes aos valores encontrados por Santos (2004), cujo estudo foi realizado em gnaisses facoidais.

As resistências calculadas no presente trabalho apresentam uma relação não linear com as porosidades dos corpos de prova.

A tabela 5.1 apresenta um resumo dos ensaios realizados neste trabalho.

Tabela 5.1- Valores médios dos ensaios realizados.

\begin{tabular}{ccccc}
\hline Parâmetros & Unidade & Rocha Sã & $\begin{array}{c}\text { Rocha } \\
\text { Medianamente } \\
\text { Alterada }\end{array}$ & $\begin{array}{c}\text { Rocha } \\
\text { Alterada }\end{array}$ \\
\hline KIC & $\mathrm{MPa} \mathrm{m}^{\wedge}(1 / 2)$ & 0,740 & 0,400 & 0,099 \\
Porosidade & $\%$ & 0,79 & 1,75 & 5,41 \\
Peso Específico Seco & $\mathrm{kN} / \mathrm{m}^{3}$ & 26,61 & 26,11 & 25,64 \\
Resistência à Tração & $\mathrm{MPa}$ & 6,33 & 3,88 & 1,58 \\
UCS & $\mathrm{MPa}$ & 68,80 & 81,32 & 28,08 \\
ISmédio & $\mathrm{MPa}$ & 5,23 & 2,36 & 0,23 \\
Qmédio & - & 61,89 & 16,22 & 16,22 \\
\hline
\end{tabular}

Os valores obtidos indiretamente nos resultados de compressão uniaxial, referentes aos ensaios de esclerometria (Q) e de point load ( $\left.\mathrm{I}_{\mathrm{S}}\right)$, mostraram-se próximos, porém muito discrepantes dos valores obtidos diretamente no ensaio de compressão uniaxial. Tal fato revelou que as equações empíricas preestabelecidas e utilizadas não forneceram bons resultados. Salientando a necessidade de se estabelecerem novas relações para as litologias estudadas, a fim de que valores mais semelhantes aos encontrados nos ensaios diretos sejam obtidos, permitir-se-á o uso destes ensaios mais simples na caracterização mecânica dessas rochas.

Para as médias da tenacidade à fratura têm-se uma redução de 45,9\% das rochas medianamente alteradas para rochas sãs, enquanto as rochas alteradas apresentam uma redução de $86,7 \%$. Portanto, o aumento do grau de alteração reduz a tenacidade à fratura das rochas gnáissicas estudadas. 


\section{2}

\section{Sugestões para futuros trabalhos}

Como sugestões para futuros trabalhos, recomenda-se:

- Aplicar a metodologia utilizada para outros tipos de rochas (ígneas, sedimentares, isotrópicas, etc.);

- Aprofundar a pesquisa nos aspectos microestruturais na propagação das fissuras;

- Comparar os resultados da tenacidade à fratura do ensaio CCNDB com diferentes ensaios. 


\section{6 \\ Referências bibliográficas}

ALMEIDA, L. C. R. Estudo Experimental da anisotropia de resistência de rochas graníticas e sua aplicação a processos de desmonte. Dissertação de Mestrado. Departamento de Geologia, IGEO/UFRJ, p. 116, 1999.

ALMEIDA, L. C. R., VARGAS, E. DO A.; DE FIGUEIREDO, R. P. Mechanical characterization of rock splitting planes in granitic rocks. International Journal of Rock Mechanics and Mining Sciences, v. 43, n. 7, p. 1139-1145, 2006.

ANDERSON, T. L. Fracture Mechanics Fundamentals and Applications. 2 $2^{\text {nd }}$ edition CRC Press, 1995.

ASTM D5731-08. Standard Test Method for Determination of the Point Load Strength Index of Rock and Application to Rock Strength Classifications. ASTM International, West Conshohocken, PA, v. 22, n. 2, p. 51-60, 2008.

ATKINSON, B. K. Fracture toughness of Tennesse sandstone and Carrara marble using the double torsion testing method. International Journal of Rock Mechanics and Mining Sciences \& Geomechanics Abstracts, v. 16, n. 1, p. 49$53,1979$.

ATKINSON, B. K. Fracture Mechanics of Rock. Academic Press, London, 1987.

AYDIN, A. The ISRM Suggested Methods for Determination of the Schmidt Hammer Rebound Hardness: Revised Version. International Journal of Rock Mechanics and Mining Sciences, v. 43, p. 627-634, 2009.

AZEVEDO, I. C. D.; MARQUES, E. A. G. Introdução à Mecânica das Rochas. Editora UFV, Viçosa, p. 363, 2002.

BACKERS, T. Punch-trough shear test (PTS-Test) of drill core a new method for $\mathrm{K}_{\text {IIC }}$ testing. Thesis (PhD) - Division of Engineering geology, Departament of Civil and Environmental Engineering, Royal Institute of Technology, Stockolm, 2001.

BARROSO, E. V. Estudo das características geológicas e do comportamento geotécnicode um perfil de intemperismo em leptinito no Rio de Janeiro. Dissertação de Mestrado. Departamento de Geologia, IGEO/UFRJ, Rio de Janeiro, p. 251, 1993.

BLUHM, J. I. Slice of a three dimensional "work of fracture" specimen. Engineering Fracture Mechanics, v. 7, n. 3, p. 593-604, 1975. 
BORTOLUCCI, A. A. Modelo de ruptura em compressão de materiais frágeis baseado na mecânica da fratura e aplicado ao efeito escala. Tese de Doutorado. Escola de Engenharia de São Carlos, Universidade de São Paulo, São Carlos, 1993.

BROCH, E. Estimation of strength anisotropy using the point load test. International Journal of Rocks Mechanics and Mining Sciences \& Geomechanics Abstracts, v. 20, n. 4, p. 181-187. 1983.

CHEN, J. F. The development of the cracked-chevron-notched Brazilian disc method for rock fracture toughness measurement. SEM Spring Conference on Experimental Mechanics, Albuquerque. Proceedings p. 18-23, 1990.

CLAESSON, J.; BOHLOLI, B. Brazilian test: Stress field and tensile strength of anisotropic rocks using an analytical solution. International Journal of Rock Mechanics and Mining Sciences, v. 39, n. 8, p. 991-1004, 2002.

CUCCURU, S.; CASINI, L.; OGGIANO, G.; CHERCHI, G. P. Can weathering improve the toughness of a fractured rock? A case study using the San Giacomo granite. Bulletin of Engineering Geology and the Environment, v. 71, n. 3, p. 557-567, 2012.

CUI, J.; JIANG, Q.; LI, S.; FENG, X.; ZHANG, M; YANG, B. Estimation of the number of specimens required for acquiring reliable rock mechanical parameters in laboratory uniaxial compression tests. Engineering Geology, v. 222, p. 186$200,2017$.

DONOVAN, J. G. Fracture toughness based models for the prediction of powder consumption, product size, and capacity of jaw crushers. Thesis (PHD). Mining and Minerals Engineering, Virginia Polytechnic Institute and State University. Blacksburg, 2003.

FENG, G.; KANG, Y.; MENG, T.; HU, Y.; LI, X. The Influence of Temperature on Mode I Fracture Toughness and Fracture Characteristics of Sandstone. Rock Mechanics and Rock Engineering, v. 50, n. 8, p. 2007-2019, 2017.

FERREIRA, L. E. T.; BITTENCOURT, T. N.; SOUSA, J. L. A. O., GETTU, R. R-curve behavior in notched beam tests of rocks. Engineering Fracture Mechanics, v. 69, p. 1845-1852, 2002.

FOWELL, R. J.; XU, C. The cracked chevron notched Brazilian disc testgeometrical considerations for practical rock fracture toughness measurement. International Journal of Rock Mechanics and Mining Sciences \& Geomechanics Abstracts, v. 30, n. 7, p. 821-824, 1993.

FOWELL, R. J.; HUDSON, J. A.; XU, C.; CHEN, J. F. Suggested Method for Determining Mode-I Fracture-Toughness Using Cracked Chevron-Notched Brazilian Disc (CCNDB) Specimens. International Journal of Rock Mechanics and Mining Sciences \& Geomechanics Abstracts, v. 32, n. 1, p. 57-64, 1995. 
GHAMGOSAR, M.; WILLIAMS, D. J.; ERARSLAN, N. Effect of anisotropy on fracture toughness and fracturing of rocks. 49th US Rock Mechanics / Geomechanics Symposium 2015, v. 4, n. October 2016, 2015.

GOMES, L. M. S. Caracterização petrográfica, análise de padrões de fraturamento e caracterização tecnológica para rochas da pedreira Bangu, Rio de Janeiro, RJ. Trabalho de conclusão de curso de graduação. Departamento de Geociências, DEGEO/UFRRJ, p. 46, 2014.

GOODMAN, R. E. Introduction to rock mechanics. $2^{\text {nd }}$ ed John Wiley \&Sons, New York, p. 562, 1989.

GRIFFITH, A. A. The Phenomena of Rupture and Flow in Solids. Philosophical transactions of the Royal Society of London. Series A, containing papers of a mathematical or physical character, v. 221, n. 1921, p. 163-198, 2016.

GUHA ROY, D.; SINGH, T. N.; KODIKARA, J.; TALUKDAR, M. Correlating the Mechanical and Physical Properties with Mode-I Fracture Toughness of Rocks. Rock Mechanics and Rock Engineering, v. 50, n. 7, p. 1941-1946, 2017.

GUO, H.; AZIZ, N. I.; SCHMIDT, L. C. Rock fracture-toughness determination by the Brazilian test. Engineering Geology, v. 33, n. 3, p. 177-188, 1993.

HASHIDA, T.; TAKAHASHI, H. Significance of AE crack monitoring in fracture toughness evaluation and non-linear rock fracture mechanic. International Journal of Rock Mechanics and Mining Sciences \& Geomechanics Abstracts, v. 30, p. 47-60, 1993.

HELMBOLD, R.; VALENÇA, J. A. G.; LEONARDOS JR, O. H. Mapa geológico do Estado da Guanabara, esc. 1:50000. MME/DNPM , p. 3, 1965.

HUANG, J.; WANG, S. An experimental investigation concerning the comprehensive fracture toughness of some brittle rocks. International Journal of Rock Mechanics and Mining Sciences \& Geomechanics Abstracts, v. 22, n. 2, p. 99-104, 1985.

INTERNATIONAL SOCIETY OF ROCK MECHANICS. Suggested methods for determining tensile strength of rock materials. International Journal of Rock Mechanics and Mining Sciences, v. 15, n. 3, p. 99-103, 1978.

INTERNATIONAL SOCIETY OF ROCK MECHANICS. Suggested methods for determining the uniaxial compressive strength and deformability or rock materials. International Journal of Rock Mechanics and Mining Sciences, v. 16, n. 2, p. 135-140, 1979a.

INTERNATIONAL SOCIETY OF ROCK MECHANICS. Suggested methods for determining water content, porosity, density, absorption and related properties and swelling and slake durability index properties. International Journal of Rock Mechanics and Mining Sciences, v. 16, n. 2, p. 141-156, $1979 \mathrm{~b}$. 
INTERNATIONAL SOCIETY OF ROCK MECHANICS. Suggested methods for determing point load strength. International Journal of Rock Mechanics and Mining Sciences, v. 22, n. 2, p. 51-60, 1985.

INTERNATIONAL SOCIETY OF ROCK MECHANICS. Suggested methods for determining the fracture toughness of rock. International Journal of Rock Mechanics and Mining Sciences, v. 25, p. 71-96, 1988.

INTERNATIONAL SOCIETY OF ROCK MECHANICS. Suggested methods for determining mode I fracture toughness using cracked chevron notched brazilian disc (CCNDB) specimens. International Journal of Rock Mechanics and Mining Sciences, v. 32, p. 57-64, 1995.

KURUPPU, M. D.; OBARA, Y.; AYATOLlAHI, M. R.; CHONG, K. P.; FUNATSU, T. ISRM-suggested method for determining the mode I static fracture toughness using semi-circular bend specimen. Rock Mechanics and Rock Engineering, v. 47, n. 1, p. 267-274, 2014.

LI, D.; WONG, L. N. Y. The brazilian disc test for rock mechanics applications: Review and new insights. Rock Mechanics and Rock Engineering, v. 46, n. 2, p. 269-287, 2013.

LI, X.; RUPERT, G.; SUMMERS, D. A.; SANTI, P.; LIU, D. Analysis of Impact Hammer Rebound to Estimate Rock Drillability. Rock Mechanics and Rock Engineering, v. 33, n. 1, p. 1-13, 2000.

MARCHIORI, D. G. A mecânica da fratura elástica e o modelo coesivo na previsão do fraturamento de rochas. Dissertação de Mestrado. Escola de Engenharia de São Carlos, Universidade de São Paulo, São Carlos, 1997.

MARQUES, E. A. G.; BARROSO, E. V.; MENEZES FILHO, A. P.; VARGAS, E. D. A. Weathering zones on metamorphic rocks from Rio de Janeiro-Physical, mineralogical and geomechanical characterization. Engineering Geology, v. 111, n. $1-4$, p. $1-18,2010$.

MENEZES FILHO, A. P. Aspectos geológico-geotécnicos de um perfil de alteração de gnaisse facoidal. Tese de Doutorado. Departamento de Engenharia Civil, PUC-Rio, Rio de Janeiro, p. 229, 1993.

NOGUEIRA, N. R. M. L. Análise petrográfica e metamórfica dos gnaisses précolisionais ocorrentes na pedreira Bangu, Rio de Janeiro, RJ. Trabalho de conclusão de curso de graduação. Departamento de Geociências, DEGEO/UFRRJ, p. 59, 2006.

PEHOVAZ-ALVAREZ, H. I. Ensaios não convencionais para determinação da tenacidade à fratura em rochas: análise e comparação. Dissertação de Mestrado. Escola de Engenharia de São Carlos, Universidade de São Paulo, São Carlos, p.238, 2004.

PIRES, F. R. M.; VALENÇA, J. G.; RIBEIRO, A. Multisage generation of granite in Rio de Janeiro, Brazil. Anais Academia Brasileira de Ciência, 54 (3), p. 563-574, 1982. 
PORTO JR., R.; VALENTE, S. C. As rochas granitoides do Norte da Serra da Pedra Branca e suas relações com as rochas encaixantes gnáissicas na região de Bangu, Rio de Janeiro, RJ. Anais do XXXV Congresso Brasileiro de Geologia, Belém, Pará, v. 3, p. 1066-1079, 1888.

PORTO JR.; R. Petrogênese das rochas do maciço da Pedra branca, Rio de Janeiro, RJ. Tese de Doutorado. Departamento de Geologia, IGEO/UFRJ, p. 231, 2004.

RUSNAK, J.; MARK, C. Using the point load test to determine the uniaxial compressive strength of coal measure rock. In proceedings of the $1^{\text {th }}$ International Conference on Gorund Control in Mining. Morgantown, West Virginia University, p 362-371. 2000.

SANTOS, A. T. C. Redução da tenacidade por intemperismo: mecanismo préruptura de maciços rochosos. Trabalho de conclusão de curso de graduação. Departamento de Geologia, IGEO/UFRJ, Rio de Janeiro, p. 69, 2004.

SCHMIDT, R. A. Fracture toughness testing of limestone. Experimental Mechanics, Esaton, v. 16, p. 161-167, 1976.

TAN, X.; KONIETZKY, H.; FRÜHWIRT, T.; DAN, D. Q. Brazilian Tests on Transversely Isotropic Rocks: Laboratory Testing and Numerical Simulations. Rock Mechanics and Rock Engineering, v. 48, n. 4, p. 1341-1351, 2015.

TAVALLALI, A.; VERVOORT, A. Effect of layer orientation on the failure of layred sandstone under Brazilian test conditions. International. Journal of Rock Mechanics and Mining Sciences, v. 47, p. 313-322, 2010.

VARGAS, E. D. A.; VELloSO, R. Q.; CHÁVEZ, L. E.; GUSMÃO, L.; AMARAL, C. P. On the effect of thermally induced stresses in failures of some rock slopes in Rio de Janeiro, Brazil. Rock Mechanics and Rock Engineering, v. 46, n. 1, p. $123-134,2012$.

VERVOORT, A.; MIN, K. B.; KONIETZKY, H.; CHO, J. W.; DINH, B. Q. D.; FRÜHWIRT, T.; TAVALLALI, A. Failure of transversely isotropic rock under Brazilian test conditions. International Journal of Rock Mechanics and Mining Sciences, v. 70, p. 343-352, 2014.

WANG, Q. Z.; XING, L. Determination of fracture toughness KIC by using the flattened Brazilian Disc specimen for rocks. Engineering Fracture Mechanics, v. 64, p. 193-201, 1999.

WANG, Q. Z.; JIA, X. M.; KOU, S. Q.; ZHANG, Z. X.; LINDQVIST, P. A. More accurate stress intensity factor derived by finite element analysis for the ISRM suggested rock fracture toughness specimen-CCNDB. International Journal of Rock Mechanics and Mining Sciences, v. 40, n. 2, p. 233-241, 2003.

WANG, Q. Z.; JIA, X. M.; WU, L. Z. Wide-range stress intensity factors for the ISRM suggested method using CCNDB specimens for rock fracture toughness tests. International Journal of Rock Mechanics and Mining Sciences, v. 41, n. 4, p. 709-716, 2004. 
WANG, H.; ZHAO, F.; HUANG, Z.; YAO, Y.; YUAN, G. Experimental Study of Mode-I Fracture Toughness for Layered Shale Based on Two ISRM-Suggested Methods. Rock Mechanics and Rock Engineering, v. 50, n. 7, p. 1933-1939, 2017.

WESTERGAARD, H. M. Bearing pressures and cracks. Journal of Applied Mechanics, New York, v. 24, p. 31-34, 1939.

WHITTAKER, B. N.; SINGH, R. N.; SUN, G. Rock fracture mechanics: principles, design and applications. Elservier Science Publishers B. V., Amsterdam, p. 570, 1992.

XU, C.; FOWELL, R. J. Stress intensity factor evaluation for cracked chevron notched Brazilian disc specimen. International Journal of Rock Mechanics and Mining Sciences \& Geomechanics Abstracts, v. 31, n. 3, p. 157-162, 1994. 